University of Louisville

ThinkIR: The University of Louisville's Institutional Repository

Electronic Theses and Dissertations

1942

\title{
The question of monastic functions on the eve of the dissolution.
}

Winona Bryan Money

University of Louisville

Follow this and additional works at: https://ir.library.louisville.edu/etd

Part of the European History Commons, and the History of Religion Commons

\section{Recommended Citation}

Money, Winona Bryan, "The question of monastic functions on the eve of the dissolution." (1942).

Electronic Theses and Dissertations. Paper 1843.

https://doi.org/10.18297/etd/1843

This Master's Thesis is brought to you for free and open access by ThinkIR: The University of Louisville's Institutional Repository. It has been accepted for inclusion in Electronic Theses and Dissertations by an authorized administrator of ThinkIR: The University of Louisville's Institutional Repository. This title appears here courtesy of the author, who has retained all other copyrights. For more information, please contact thinkir@louisville.edu. 
UNIVEASITY OP IOUISTILLE

THE QURSTION OF WOHASTC FUHCTIONS

OI THE BVE OF THE DISBOLOTION

\author{
A Disartation \\ submitted to the raoulty \\ Of the Graduate Sohool of the Dniversity of Ioulavilie \\ In partial Fulfilimont of the \\ Requirements for the Degree \\ of unster of Lits
}

Dopartment of History

By

Winona Bryan Dney

Year

1942 
MAMS OP STUDBRT:

TITE OF THESIS: THB QUESTIOH OP MOHAETIC YULCTIONS OR THE RVB OF TRE DIS SOLUM

APPROTED BY A RBADIMG COATTM COLPOSED OF THE FOLTOVIHG HEMBRES:

WAME OP DIRECTOR:

mate: $20 y=26,194^{2}$ 
THE QUHSTION OP IOHASTIC FUTCTIOHS

Of THE LVE OP TEE DISSOLUTIOA 
I wish to express gratitude to Dr. Jamos K. Read, the Univeraity of Loularille, for his raluable and holpful assistance and for the kind generosity of the onirereity of Loulerille Ilbrary; the Harper Iibrary, Jniverelty of Chtoego; the Dirinity Ifbrery, Jal rersity of Chiosgo; the Iewberry Llbrary, Chloage, Illinois; the Chicago Free Publie Iibrary; and the Ioularille Pree Publie Iibrary. 
TLBLE OF CONTENTS 
TABLE OF CONTENTS

PAGE

INTRODUCTIOI . . . . . . . . . . . . 1 CHAPTER

I. BACKGROUND OF SIXTEEHTH CERTURY BIGIIAID ............. 1

Effects of the Bleck Death on monastic life -- Effects of the

var of the Roses -- Influence of earlier attacks on the Churoh -Dissolution 1dea hermonious with the spirit of the age -. The Tudor Dynasty.

II. USUAT MOHASTIC DUTIES AND ACTIVITIRS . 24 Prajers -- Hospltality -- Almogiring and cherity -- Fduostion.

III. HXTENT OF MOMASTIC POSSESSIONS IN

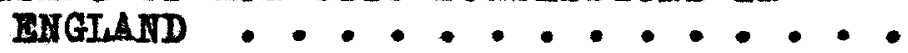
Amount of monastic land and woalth -How land and werlth were obtained -Income of the monesteries.

IV. IHTERTERHICES II MOKASTIC IIPE . . . Lay interferences -- Foolesiastical interferences. 
V. BREAKDOWI OF MOHASTIC IDEAIS AID PRACTICES BETORE THE DISSOLUTIOH . 78

Dieregard of the four p111ars of monastioism - Neglect of monsstic

duties and activities.

VI. RRASONS FOR THE DECLINE OF MOHASTIC IIPE

Realization of need for reform by the Church - Subordination of monarchy to Charch anthority -Immantios -- Ion-residence of the olergy -- Pinancial aificultios -Pactions vithin the monasteries -Fal ae relios and onperstitions -Lack of progress - Monastie activities as gumed by other institutions.

VII. UNRHLIABIIITY OF EVIDENCE FOR THS SUPPRASSIOI ............. 150

Time involred in making the survegs -Type of men who mde the surreye -False reports are to dissention within the monasteries - Report of the Comissioners - Question of the Black Boot. 
IITRODOCTIOE 


\section{INRODOCTION}

"Latrimonial discords, have from the dags of Holon of Troy, been the fruitful source of public calamities; and one of the most decisive erents in English history, the breach with the Church of Rome, found its

oceasion in the divorce of catherine of Aragon." I

In the yoar 1509 King Henry the Seronth of Fnglend died. The winter of the old reign was passed and opring, in the person of young Henry the Elghth, proved not only to be glorious, bat also rerolntionary. In 1527 he, startled the Chrietian world by announcing his intention to diroree his logal wife, Catherine of Aragon, the roby cauaing the breach between Iondon and Reme. I fow years later, with the ald of Cromell he began a movement which oulminated in 1539 in the complete dissolution of all monastio houses in Fingland. "The old monastic chapols had boen prolanod, plundered and dismantled, and now served es pigeon10fts. 2 Thus a description of what once had been pointed to as beautiful landmarks of the Inglish countryaide. Vere Henry's actions in the digsolution fustified? Had the religfous houses become as degraded as his agents

$$
\begin{aligned}
& \text { 1. 1. Fo Pollard, Henry the fishth, p. I78. } \\
& \text { 2. G. Constant, the Reformation in England, p. } 171 \text {. }
\end{aligned}
$$


claimod, and thes worthy of a dissolntion? or were the clolstered ones falsely acoused?

In answering these questions, it is very difficult to arrive at any objectire and unbiased conclusion. The historian's path is a treacherous one. The mejority of authoritios on the subject take quite a determined standpoint. The anti-Catholies contend that the religtous bodies in Ingland had fallen so far below the 1deals and practices originally establiahed for them that they well deserved the fate mich befell them. on the other hand, the pro-cathollo writers assert that, for the wost part, the religious in Bngland were oontinaing to perform the ir functione to the best of their ability. The evidenoe on which the were convieted was propagenda, created for a opocified purpose by Henry and his agente. The XIng was not so interested in whether or not the monastic functions were being performed, as he was covetous of the monastic lands and wealth. Thus the historion who is seoking the truth finds himself entanglod in a web of very biaged meterial. Fo arrivo at some semblance of truth is indeed difficult.

It hardig seoms possible thet as many religious houses in ingland could have been so completely degraded a Henry's agents would have us beliero. However, it is impossible to eocept the fact thet many were not in noed 
of a severe reformation. For is it not true that where there is so much omoke there mast be some fire? It only seeme probable thet the slow, smoldering, unchocked flame that was gradually, but definitely andermining the monastic institutions in England was farmed into a reging, devastating inferno by the carefully and atrategleally planned propaganda of Henry and his agents. Thus this early campaign of propagande only bronght to destruction at an earlier date the already doomed monastories of Ingland. 
CHAPTER I

BACKGROUID OF SIXTEENTH CENTURY BITIIATD 
CHAPPER I

BACKGROUID OF SIXTHENTH CENTURY BNGTAND

In the jear 1047 A.D. Raoul Gleber, a Benedictine chronicler wrote, "It is as if the whole world had throm off the rags of its ancient time, and had arrayed 1tself in the white robes of the Churchos." spence, the Bnglioh historian, refers to the eleventh oentury as the time of the awakening of the Festern churoh. 1 However, four conturie later, in the latter part of the fifteenth century, another historian describes the Church as going through one of the darkest periods of its history. 2 This may bo a olight exaggeration of the extent to which the religions organizations had declined by the sirteenth contury, for after all there was still muoh good being done. Hevertbeless, it wes true thet something had happened in the conturies between 1100 and 1600 which caveed a declino in ohurch life. That had happened?

In the short apan of a little more than a handred years Bngland experienced two national catastrophes, the two terrible plagues, disease and war. In the middle of p. 64.

1. H. D. H. spence, History of the kngligh Churoh,

2. T. Capes, Pngligh Churoh in Fourteonth and Pifteenth Centuries, p. 214. 
the fourteenth century the dreaded plague, the Black Death swept over the country, taking its toll of Iives everymere. From 1348 until 1350 the ravages of this diserse were folt in every part of the British Iale; death and desolation ruled supreme; peoplo died and olrcumstances changed. Thus certain social and economic changes were brought about that were to hare far-reaching effects on the fat ure history of the country and 1t poople.

After the scourge of the Black Death had passed, Bngland was left a desolate country. From 1348-1350 thousands of people had died 28 a result of this dreadful plague. great many accounts place the death toll as high es (50\% or) one-helf of the entire population. 1 Although it is hard to believe that as many as $50 \%$ of the English people were wiped out, one can 80 too far in minimizing its ravages. W. E. Iunt saye, for instance, that the death rate was probably only olightly higher then in this country during the influenze opidemie of 1917. Sucoooding orents (o.g. Statute of Laborers) show that by 1350 there was a noticeable decrease in the country's population. The cloistered groupe prored to be no exception in this case. Death visited the

p. 337 .

1. A. C. FIlck, Deoline of the Hodevel churah, 
monesteries, as well as the nobles' castles and the poor man's hut. As the monks went forth from their homes to help minister to the sick and dying they came in contect with the disease and many perished. "In some plecer whole monastic commeities wero wiped ont, in others the B1shop and all his chepter died."I sponce has ostimated that two-thirds, or at least considerably wore than one-half of the religions died. "In the ranks of those then lost, were many of the most earnest and deroted. The gaps thus made were very slowly and imperfectly filled." 2

Thus the numbers in the religious houses were groatly reduced and in many cases the newly-made vacancies were never refilled.

The monastery of St. Albans, one of the great typical monastic institutions of the Fest, sank to, and remained at, half its old numbers. The same was roughly true of the great monestic houses throughout Burope. Some, later, recelved further endowments and greater numbers. But the monastio institution, like all other institutions in Europe, was hit in its vitals, and the effect of the blow was felt for generations. 3

It has boon found that ap until the time of the dissolntion some houses still had very f'ew members. The case of Bildewas Abbey might be cited. "About the time of

$$
\begin{aligned}
& \text { 1. H. Belloc, How the Relormation Heppened, p. } 46 . \\
& \text { 2. Spence, op. cit., pp. } 102-108 \text {. } \\
& \text { 3. Belloc, op. oit., p. } 46 \text {. }
\end{aligned}
$$


the enppression, here were twelve monks, who were endowed with 110pds. 198. and 3 pence per annum, according to Dagdale; but Speed estimates the value at I 129,68 . $10 \mathrm{~d} . " 1$

If the number of inhabitants in the religions houses were thas reduced to a fraction of their former namber and these racancies were not filled, it is only natural that some of the work which had proviously been carried on was now neglected. In cases where the work was done, it could not be carried on elticiently by two or three monk or nuns, where twelve had formerly been required. Such was the case of Bromehall Priory, where only two or three nuns resided. 2

Labour was rery scarce at this time, especially among the poorer olasses.

The sheep and oattle strayed through the fields and corn, and there was none left who could drive them out.' Harrests rotted on the ground. The domand was so great for help that wages rose to a point where the landlords complained and sought to regulate both labour and pay by the statute of Labourers in 1351.3

Therefore, help was not easy to get and whet work the monks did not do was left undone, for thore were no

1. T. PhIIIP8, the Higtory and Intrapties oI shremebury, Vol. I, p. Bt TAppendisT.

2. I. I. Taunton, Thomas Nolsey Legate and Reformer, p. 84 .

3. FIIck, op. c1t., p. 337 . 
others to do it for them. This si tuation was unaroidable in 1350 , but by 1500 those houses that had falled to replenioh their ranks with the necessary numbers oould expect little sympathy.

The decline in number and the neglect of dutio was also accompanied by growing laxty of discipline. 1. Franciscan annalist of that time writes: "The masters of regular discipline and the seniors of experience being carried off, the rigours of discipline, being relaxed, could not be ronewed by the youths reoeired without the necessary training rather to fill the depopulated houses."il It took many years to oducate and train the new monks to the point where they could expect to fill the places racated by the experienced leadera taken by the plague. In some houses the patience and time required for this takk were lacking, and the new inexperienced monks placed in responsible positions could not possibly keep as good control over their charge as their more learned predecessors had done. There is one story told of a very amall lad belng appointed to a responsible position.

4 certain biahop having receired a gift of a basket of peers, asked them who sat at meat with him, to whose custody he should commit them. His young nephew, to whom he had even then committed

1. Spence, op. OIt.. p. 10Z. 
an archdeaconry arewored and said, 'I will keep the pears.' To whom his uncle answered, 'Thor rascel, ill wouldest thon keop thom." Then sald a certain honest man who was there present, 10 wrotch. How hast thon dared to comit an archdeaconry of so many souls to this jouth, tp whom thou dareat not commit a baket of pears?'1

To all the other handicaps under which the monks strugglod after the soige of the Black Dosth, was added that of financial difficalty. The monastic income were considerably lowered imediately following the year 1350 and continned to be for several years thereafter. 2 rany of their tenants died or moved elsewhere, leaving the monastic Ifelds unenltivated. Thus the income formerly recoived from this wasting land was miseing, plus large gifts which generous nobles probably felt that at this critical time they conld not afford to make. However, the monasteries recovered more quickly from their financial burdens than they aid from the decrease in numbers and the neglect of duties and discipline.

The second plague which England experienced between 1350 and 1500 was that of varfare, namely the Wars of the koses. Wars between nations are disastrons onough, but a country torn by a civil war, wh thamily fighting against family, brother against brother, is

\footnotetext{
1. 6. 6. Contron, IIte in the Irdale lgee,

T01. I, p. 94. p. 27 .

2. R. Graham, Esagr on Engligh Yonasteries,
} 
eren more tragie. This was the condition in fingland during the Tars of the Roses. From the time of Henry VI unt1l Henry VII Inally seized the throne in 1485 , Ingland wes torn by the conflict botween the Drake of York and his followers, and the loyal supporters of Henry VI and the Lancastrian famly, in their struggle for the throne.

For thirty jears tho wars continued. There was not oonstant fighting, a jear or two often lapsing between batties, but the feoling of hate and suspioion was overywere and the country remained in a deplorable state. There was no permanent contral government, no stabilized anthority in any one person or group of persons, many members of the noble families were doad or doomed to die bofore the conflict wes finally settlod, and every phase of the nation's Iffo was disrupted. A deseription of the prevaling conditions revesle that:

In war of suceession, where the great families Tere divided in their allegiance, and supported their riral clalmants in evenly balanoed numbers, the invoteraoy of the conflict increased with its duration, and propagated itself from generation to generstion. Erery Iamily was in blood fend with its neighbours, and chlldron, as they grew to manhood, inherited their duty of revenging their father's death. Ho effort of imagination can reproduce to us the atate of this country in the fatal yoars which intervened between the first rising of the Dake of York and the battlo of Bosworth; and experience too truly convinced Henry VII that the war ceased only from general 
exhaustion, bat not because there was no will to continue $1 t .1$

What of the religious houses daring this period of nationwide confliet? Although they had ondared their share of suffering and death during the siege of the Blaok Death, now the cloistered ones were littlo disturbed by the general strile in the outside world. In fact, during the thirty joars when the rest of the country was porishing, they onjoyed relative prosperity. Mang of the nobles who formerly had made demands on the monasteries and had interfered in their daily 11 fo, woro now either ongaged in fighting for their colors, or had already boon slain in battle. Ilkowlse, those in authority who might have hed some power over the religioue were now elsewhere occupied, and probably felt that their position was already woak onough without incurring the onmity of the monastic houses.

Therefore, the monateries were practically froe from any lay interference for over thirty years. Their life continued as usual, they became woalthier, and theire was the one institution in Inglend wich stood out above the destruction and chaos of oivil warfare as powerful, wealthy, and stolid os it had been before. "The abbots and the bishope almost alone had readj money

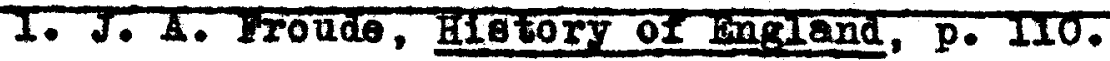


In these troubled times, and used it to buy ap, at nominal prices, the lands depreciated by the ofvil wars. The destruetion of the nobility, moreover, in these long and terrible struggles, helped them, for while the territorial aristooracy had well-nigh periohod, that of the Church remained intact."l "The Imwanity which they onjoyed from the general eufferings of the civil war contribated to deoeive them." 2

Henry VIII was the firet to bring about the diselution of all the monasteries in ingland, but he was by no moans the first to attack the religious groups. For many yeare before this time certain people had come forth, some to critiolse the church organizations, others to try to reform them. One of the earliest refomers to attack the monks was Vyoliffo. His purpose was not to ohange the doctrines of the charch, but to reform the Chureh from within. He oomplained that the monik neglected their religious duties to care for their property and he frequently roferred to them as "posegseionerw."3 In critielsing them he sald: "These unreliglous that have possessions, they commonly have red

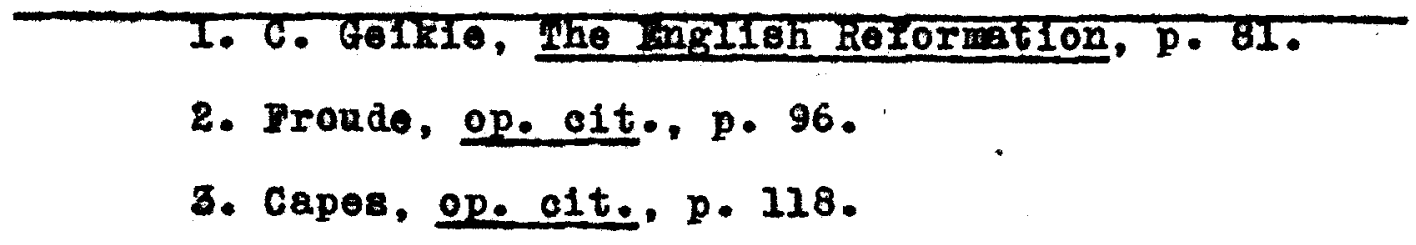


cheeks and great bellies.'nl

'Dead dogs' they were, of whom the realm should be freed. In his traots he oalls their cloigters 'Cain's cestles.' Once whon Wyoliffe was thought to be dying a company of exasperated friars surrounded his bed and exhorted him to repent, but he found atrength to raise himself, and with prophetio instinct exclaimed that he should jet iire to denonnoe thoir errors again.2

Tycliffo's successor in the campaign to "olean up" religions life was the satirical scholar, Brasmus. He principally criticised the monks' 1dle isolation and greedy acquisitiveness which gradually led to the monopoly of monastic wealth by a chosen for.

It was intolerable that large bodies of man should live in idleness, waited on by troops of bervants, When the revenes thus wastod had been giren for the apport of learning, the exero 1se of hospite$11 \mathrm{ty}$, and the relief of the old, the infirm, and the poor; that institution which were bound by their statutes to hare a certain number of members should deliberately allow that number to sink to helf or even a third, that there might be more money to divide among the rest: above all that there should be, over Bngland, a vast notwork of ostoblishments, nominally for the Glory of God, and the edification of the people by a righteons example, but in practice worlaig, grasping, sensual, and hypocriticel.3

Fraums was eton more biting in his critiolam then

1. IbIa., p. II8.

2. W. H. Beckett, Englieh Reformation of the S1xteonth Contury, p. 70 .

3. Ge1kie, op. cit., p. 257 . 
Wyeliffe. He hated the monks and friars and referred to them in such uncomplimentary terms as "pest and vermin, rile rascals, bate and orls who hated light."l In his preige of Bolly, which was an open attack on the monks and which caused considerable comment among the people of that time, he spoke of the "brain alck fools who stjle themselves monks. ${ }^{2}$ In regard to vows of celibacy he decried the fact that: ". . they [the monks] have licence to go with harlots, but they mast not mary wives. They may keop concubines. If they take wives, they are thrown to the flemes."'3 Brasme felt that the religions, instead of lamenting their sine were conveniently overlooking them: ". . they faney they can please God by snorting in their throsts. ${ }^{4}$ In a letter to servatias, he wroto in 1514: "Your relifion is your dress; -- your religlous orders, es gou cell them, have done the Church smell service."5 Iater, in 1517, Rrasmus wrote to Pirkheimer: "The Pope

tion, p. 228.

2. D. Brasmus, Praige of Fo11y, p. 143.

3. Hagre, op. clt., p. 228.

4. C. D. Wamer, od., Morld'g Best Ilterature, Vol. IIV, p. 5532.

5. Ibia., p. 5532 . 
himself is afraid to provoke the monks. Those mretches in disguise of poverty are the tyrants of the Chriation $\operatorname{mor} 1 \mathrm{~d} . \mathrm{m}^{\mathrm{I}}$

Dyoliffe and Erasmas were out standing charactera who dared to critioize and denounce the strongholds of the namerous monks and friars. Although these tro name are well-known to history, they were not the only ones who realized that some reform was necessary. For Insterce, B1shop Grossoteste in 2250 foresam the neod for monastic reform, bet unfortunately found that it was Impossible to do anything about it: ". . . the gold of the monte prerailed with the pope more then the elaim for monaaterial reform. 'o money, money, what can't thou not do in the court of Rome?' was the disappointed prelate'a exclametion." 2

Ifkewise, Arohbishop Bourchier realized the neod for reform and in 1456 in his comiseion to reform the religions, he said:

vany $111101 t$ and criminal concublnages, fornications, and adulteries are encouraged among our poople; deslarations of sucoession are set aside, and made rold. Whorefore wo, desiring with what diligence we can to stop so many and sreat dangers, grant jol, in whose fidelity and ectivity wo have confldence in the Iord, full power dulg to correct and reform such defects, crimes, and excesses, and

1. Ibid., p. 5532.

8. Beckett, op. o1t., p. 38 . 
(wo grant you) the apostates, if jou find anj to, to be punishod, and others, moreover, failing in the premises or any of the premises or notorionsly tainted with ang aisgrace, so far as ne are concerned, according to the demande of $1 \mathrm{aw}$, to be well admonished or cansed to be admonished by our anthority. 1

Bven the popes, namely Innocent III, Honorias III, and oregory IX tried their hand at reforming the cloisters, but with 1ittle snovese. 2 paring the reign of Henry VII, Cardinal Lorton made a visitation of the monasteries. The purpose of this visitation was not to prove that the monesteries rere "hotbeds of vice," but in the course of the examinations the cerdinal discovered that eren among many of the great abbeys there were flagrant example of vice and corrupt Iiving. Hor was this charge Iimitod to the great abbejs, for similar charges were made egaingt some of the smaller honses. Cardinal Morton believed that the monastio superior: were the instigators of this profilgacy, with their abordinates following in their worldy footsteps. 3 Pinal1y, after attempts at reform by scholars, prelates, and popes had proved failures, the king intervened and tried his hend at reform. Honry VII had an

1. H. Gee and $W \cdot$ J. Hardy, Docnments IIfestretire of English Charch History, p. 14 .

2. C. R. Cheney. Ipiscopal Visitation of Monesteries in the Ihisteenth Century, p. TH. 8. A. B. Innes, Fngland Unaer the Tudore, p. 55. 
aet passed by parliament, by which ho hoped some of the existing conditions might be remodied.

'For the sure and likely reformation of priests, clerks, and religious men, capablo, or by their demerits openly noised of inoonsistent living in their bodies, contrary to their order, be it onacted--that it be lawiul to all archbishops and bishops, and other ordinaries having opiscopal furiodetion, to panish and chastise such religious men, being within the bounds of their jurisdiction, as shall bo convict before them, by lawfal proof, of adultery, fornification, incest, or other fleshly incontinency, by comitting them to rard and prison, there to remain for such time as shall be thought convenient for the quality of their trespasses.'I

Mumerous other instances could be cited where, before the dissolution, attempts were made to remodJ conditions that mat here existed in some religions houses. 1lthough these efforts fell short of their objective, they aucceoded in one thing, namely, in stirring up some public opinion agatnst the religious houses. For instanos, during Fycliffe's time one London woman became very aroused against the abuess in the church.

She sat up an altar in her chamber and taught hor danghter to burlesque the action of the priest in the solemn function of the mass, with drese and tonsure all complete, continuing the practice til it reached the bishop's ears, and the offenders were made to do penance for their sin.?

Demonetration like this one not only took place,

1. Fronde, Op. CIE., p. 96.

8. Capos, op. cit., p. 147 . 
but pamphlots and poems were publishod, whioh if road, were bound to influenee public opinion. Two poems, in particular, show the existing lack of respect for the religions.

All wiakednese that men can tell
Reignoth them among:
There shall no soul have room in hell,
Of friars there is suoh a throng.

Thai say that that distroye synne, and thai mayntene men moste therinne; For had man slayn al his kynne, Go ohogre him at a frere, and for lesse than a payre of shone He wyl assoli him olene and sone, Ind say the syme that he has done E1s soule shal never dere (harm).8

Perhaps the most well known pamphlet of the time, a satire on the monke and friars, was the supplication por Beggere. It referred to the monk as "Holy Thieves do nothing," 3 and complained that the roal begsare throughout the lingdom were starving and dying becanse of the monagtic ones. "lanother sort, not of impotent, but of strong, puiseant, and counterfeit, holy and 1dio beggars and ragabonds', had 'araftily crept into the realm', and had 'increased into a kingdom. $n^{4}$ "The Fagiand, p. 171.

1. Capes, Op. CIt., p. 15R.

2. 1. W. Patterson, History of the Church of

3. S. Fish, A Supplication For the Beggara, p. 6 . 4. Geikie, op. oit., pp. 258-259. 
'supplication' ends with the rough advice, noteworthy as a sign of the timer: '. . Tie these holg Iale thiever to carts, to be whipped naked about erery market town till they fall to labour.: $n^{l}$

Pablished in 1527, this bitter satire proved to be popular for several years. Even the king is supposed to hare been secreted a copy, and after haring hed it read to him, was askod for his opinion. According to Foxe, Henry roplied: "If a man should pall down an old stone wall, and should begin at the lower part, the upper part thereof might chance to fall upon his head.' ${ }^{2}$

"Il the wonder-working changes -- the ner learning, the marvelong invention of printing, the great arakening of the people under Tyeliffe and his followers-was ignored by the men to whom the charge of the charch was entrusted. But a time of great changes was at hand. "3 The pathetio part is that the church was aware of ita reaknesses and shortcomings and failed to act before it was too 1ate. The speches of the reformers, the poems, the pamphlets, and satires published about the monasteries only serred to pare the rosd for Henry's campaign of

$$
\begin{aligned}
& \text { 1. IbId., p. } 260 \text {. } \\
& \text { 2. Froude, op. oit., p. } 104 . \\
& \text { 3. Spence, op. cit., p. } 107 .
\end{aligned}
$$


propaganda which followed not many yoars later. Very fortunately for the king, whon ho decided to act against the eloloters, he found that his work had already been begun by tyoliffe, Erasmus, and the others. All he had to do was to take it up where they had left off.

In considering the ineritableness of the dissolution one does not have to accept the ides of the fatalist who belieres that things that are to be, $⿴ 111$ be, regardese -- bat rather that the dissolution was unavoldable becane it was harmonions with the opirit of the age. This was an ago of awakening, of rising from the sleop and Inactirity of the Midale Ages. Ifor inventions were being planned and new ideas were being formed, which were to revolationize the old order of things. It was an age of change from the old and decaying to the new and progressive. If the old refused to ohange or modify its actions, it was swept away in the path of the ner.

vang people of the time felt that the "monkish ideal was antiquated." I Nodern thinkers could not reconclie the ides of complete withdrawal and seclusion from modern life, with that of aseful, good life. The monasteries had undoubtedly done splendid, useful work Englend, $p \cdot 183$. 
In the past. Their mode of life had been accepted by many people. Countlese indiriduals had boen oducated and trained within the cloistered walls, while mang more lived helpful I1res there. However, this ides of aeclusion as a prerequisite for good deods was constantiy bocoming more and more incongruous with the increasing secular character of the times. Whereas ascoticiam lormerly had boen universally approved, it was beginning to be more Irequently questioned, doubted and finally rojected as the ideal way of iffe. "The monastio ideal of going out of the world to seek something, which cannot be valued in terms of pounds, hillings, and pence, ia abhorrent to a busy, industrial ago; and overy principle is hated most when it most is nooded."I

Even prelates of the Church were beginning to question whether the monasteries were still as useful as they had been in former days. One wrote to the Arohbishop of York: "'There are meny and very great foundetions of this kind, which it is commonly said are net the profitable to God nor men; for mon are neither trained in them to lire regularly as monis for the honour of God, nor brought up to arms to defend their country. 'n2

\footnotetext{
1. Pollard, op. e1t., p. 342.

2. F. Warnor, Ecolesiastical History of England,
} Vol. I, p. 148 . 
The monastic conflict in Fingland was inovitable. Too much hed occurred durling the preceding centuries to delay the blow indefinitely.

The Reformetion was not the work of a day. Ita foundatione were laid deep in the nature of thinge. Ite roots lag in the ages. Its causes were the cooperation of the thoughts of many thinkers and the erents of many years. It was the result of a deeply laid train of coincidences. The great thinge that mark an age, and the groat mon that make history, converged as if by arrangement. It was not acoidental; it was providential."

"Wo may only venture to exprese an opinion that if the dissolution had not taken place in the reign of Hemry VIII, 1t would have come about sooner or later on account of the great riches the monseteries possessed and the rether dangerone quantity of land they hold. "I and along the same 11ne: "If Henry VIII hed not quarreled with the Pope over the metter of divorce, the Reformation would hare come all the same, though in point of time it would have been later, and the circumstances rould have boen difierent. $\$ 3$

By 1535 the continent was alroady feeling the effecta of the Reformation. Iuther and his followers had started movemente againgt the church which were having 1. Hague, Op. CIt., p. 218.

2. J. T. Cley, Yorkshire Monasteries Suppression Papers, p. 1 il. 3. Patterson, op. cit., p. 208. 
far-reaching consequences. HOW could kngland expect to excape this new deluge? She could not wall herself in according to the chinese technique, or out oft ell communication with the rest of Europe. Therefore, it was only natural that these now ideas would creep into the country, and once there, their effects were bound to be Ielt sooner or later. Fhother in the reign of Henry VIII or James I, only time rould tell.

Had Henry VII been a weaker, 1088 determined king, the dissolution would probably not have occurred as soon as it did in ingland. I Henry was only eighteen years of age when he came to the throne, but he was able to assume the responsibilitios that were placed apon him. He was well-educated, well-informed, and a king who was prepared to rule as well as reign. Inke owen Pike in A History of Crime in lingland describes "Blutt King Hal" thus: "'. . the king, the whole king, and nothing but

1. h. W. Vishart, short H1story of Honks and Honasterles, p. 292: "If ho had possesed lose intellisence, conrage, and ambition, he would not nor be as conspicuous for his vices, but the history of human liberty and Iree institutions, ospecially in ingland, would have been vastly different. His praiseworthy traits were not sutiliciently strong to onable him to control his inherited passions, but they were too regnant to permit him to submit without a struggle to the hierarchy which had dominated his country 80 many centuries. Such was 'The majestic lord, that broke the bonds of Rome." 
21

the king."nl He has also been known as "Machiavelli's prince in action. "2 Henry was king first, last and almajs, and none were allowed to forget that fact, the religious organizations proving no exception.

The Tudor dyaasty was still young when Henry oame to the throne, and the conditions under which it existed were new to Inglish history. Instead of being enpported by the nobility and the aristocratic groupe as the English kings had formerly been, the rudors had behind them the new middle classes. Lfter the Wars of the Roses a great many of the heads of the noble families and their followers had been kllled, leaving the country rather depleted of powertul nobles. Those who had sarvired the conflict were in a weakened condition financially, their fortunes exhansted, their estates demolished, and their lands wasting. Therefore, when the Tudors came into power they found that the rising influence in the country was not the old broken-dom nobility, but the nowly-rich merchants and middle classes, Who had been gaining wealth and prominence in the nation, While the nobles were foolishly killing one another. The second of the Tudor monarohs was not as economical as his Iether had boen. "He [Henry VIII]

1. Wahart, op. c1t., p. 290.

2. C. Read, the Tudors, p. 55 . 
inherited great treasure chest, accumulated by the thrift of Henry VII, hil father." ${ }^{1}$ However, the young ruler had diseipated his father's wealth in wars with Scotland and France. In fact, by 1525 he had found that not enough money could be raised through taxation to carry on his campaigns: ". - taxation was too elastic to depend upon in emergenciea." 2 Therofore, whenever a chance arose to increase the royel income, Henry did not overlook it. such was the case with the monasteries. Besides the factor of money involred, there was also that of securing the allegiance of the middle classes. They had supported the Tudors during the reign of Henry VII, but how long could this backing be depended upon? "Kachiarelit's prince in action" wanted to make oertain that his dynesty was enduring. "Woolthy merchant s longed to have estates in the country that they might become gentlemen." This being the case, what could better cement the loyalty of the new defenders of the crown than the gift by one of the Tudors of large estates of fertile acres of valuable monastic land?

By the beginning of the sixteonth century fngland

of Ingland. p. 146 .

2. Ibid., p. 146.

3. Constent, op. cit., p. 151 . 
had entered upon an era of great transition. The Black Plague, the Warg of the Roses, the writinge of Wyoliffe, Eregma, and Firh, the teachings of Iuther and his followers, the invention of the printing press and other modern instruments, and the rise of a new dynasty backed by a new class were $a l l$ to have effect, either directly or indirectly, on the age-0ld eloisters. Mindful of these things, let us now tarn a page to the sixteenth century, and view the monesteries as they were on the ere of their diseolation. 


\section{CHAPTER II}

USUAI MONASTIC DUTIRS AND ACTIVITIES 


\section{USUAI MOHASTIC DUTIES AITD ACTIVITIRS}

The ideal monastic iffe was not ono of idleness and inaotivity. Although the monks were withdrawn from the world, they had cortain duties which they andertook to perform to the best of thoir ability. These monastio dutiea were, in reality, services that they rendered to all mankind, services for which the silent, grey-cloaked Iigurea are still remembered, even though their once glorione establishment have long aince been destrojed and forgotten.

The duties or actirities which the monks performed might be classed under four general hoadings: pragers, hospitality, almsiving, and oducation. The first duty to be considered is that of prayers. The cloistered ones apent much time each day at their prayers, and rightly they should, for there were many for whom they wore obligated to pray. The founder of monastery alwayg made certain, while he was living, that the inm tes never forgot him and, in death, his memory was recalled by the pragers seid for his departed soul. Besides the prajers due to the decessed founders, the present patron also demanded his share. "The enthusiasm of the noble founders who endowed the convents wes 
stirred by the sense of the agcetic aims of the recluses, and by some hope to gain the merit of their prajere. $=1$

The task of praying for all the deceased founders and patrons was a montous one in 1tself, but added to that the monks and nuns were supposed to pay their respects to the deperted souls of all the former superiors of their house. Considering the many conturies that somo of the older monasteries had been in existence and the many officers that the had had, this proved rather an endless taek. If the monks had really been conscientious about it they would have been on their knees from dawn to sunset. The convent of Barking found the tagk so big an andertaking that the abbese decreod that the annitersaries of abbesses who had been dead over one hundred years would no longer be observed. 2

The largest group to which the religious owed their prayers was the rast sea of all Christian souls. The religions were supposed to perform their duties for these people feithiuly and without neglect. The decessed founders, the present patron, the departed

1. Capes, op. Cit., p. 284.
2. G. Baskerville, Fnglish Monks and the
Suppression of the vonasterieg, p. 21.


abbots and abbesses, and all Christion souls were to be remembered in their daily prayers. Whether these tasks were carried out as they wero supposed to bo shall be discussed later. The purpose here is to montion briefly the monastic activitiea.

The second duty which the religious houses were expected to perform wa that of hospitality. Today this seoms an umeoessary task to expect the religione to undertake, but in the dags when hotels were unknown and small inns were poorly equipped and long distences apart, this work of the monke wae most welcome to any traveller. The hospitality of the houses was not Iimited to ang one group of people. Petrons, kings, nobles, and or dinary trarellers, all were privileged to enjoy 1t, if they deatred.

some cloisters, especially the larger ones, had a grest house separate from the monastery itself, where travellers might stop to rest as they journeyed along the countryaide. In the Rites of Durham such a place is doacribed.

There was a famous house of hospitality, called the Guest Hall, within the Abbey garth of Durham, on the west side, towards the water, the Terrar of the house being master thereof, as one appointed to gire entertainment to all states, both noble, gentle, and whatsoever degree that came thither as strangers, their entertainment not being inferior to any place in Bngland, both for the goodness of their diet, the street and dainty furniture of thoir lodgings, and generally 
all things necessary for travellers. And, withal, this entertainment continuing, (the monks) not Filing or commanding any man to depart, upon his honest and good bohaviour. This hall is goodiy, brave place, wach like unto the body of a chmoh, with vory fair pillars upporting it on oither aide, and in the midst of the hall a most large range for fire. The chamber and lodgings belonging to it were oweetly kept and so richly furnished that they were not unplossant to lie in, ospecialiy one chamber called the 'king's chamber'. deserving the name. In that the king himself might rery well have lain in it, for the princely linen thereof.' 1

"Pinally, they [the monasteries] made it a sacred duty to show hospitality to the traveller, and whethor man was faring acroas the berder, or king or princess were making progress through Bngland, the monastery suppliod both food and lodging." 2 FaturallJ the king or the petron of a house recelred better accomodation than an ordinary wayfarer. Then an important personage stopped to share a house's hospitality, elaborate preparatione were made to see thet excellent food was served and that thair gueste' visit was a pleasant one. Some monasteries even employed professional minstrels and actors to amase their guests so that the evening would not bo dull and boring. "In Pinchale Priory there was a 'players' chamber', in which actors were lodged or entertainments given. The accounts of many houses show how wach money
1. Lbbot Gasquat, mg1igh Lonas tic IIIe, p. 31. 2. Honry Q00, The Reformation Poriod, p. 90. 
was spent in hiring troupes of mimes to entertain guests."I Often a king, or member of the nobility, and especisly the patrons, would spend long periods at a timo viditing the monastery. Although no fees were charged for their accomodations, they uanally expected - gift upon the departare of their guest, which would more than compensate them for their trouble. Somotimes the monks were mistaken in the liberality of their guests, as in the c8se of King John, and sweh guests as he were not always anticipated with joj.

'To thought', wrote Jocelin of Brakeland, 'that the King (John) came to make offering of seme matter, but all he offered was one silken oloth, which his servants had borroved from our sacrist, and to this day hare not paid for. He avalled himself of the hospltality of St. Edmand, Which Tas attended with enormous expense, and upon his departure bestowed nothing at all either of honour or profit upon the eaint, sare three pence sterling, which he offered at mass on the day of his departure.' Thet was not the kind of guest that was wanted.2

In apite of the fact that the ordinary traveller was not as royally entertained as the more illustrions monastie guests, he nevertheless preferred the hospitality of a religious house to stopping a medietal inn. The inns of the fourteenth and fifteenth century were not exactly ingpiring places to visit. They were usualig frequented by a rowdy cless of peoplo

1. Bagkervilie, op. cIt., p. $2 \%$
2. Ibid., p. 28 .


and their accommodations were miserable. The reatfulness of a religious house was a rellef after the noisy, stuffy atmosphere of one of these inns.

Hataral1y travellers preferred staying at monasteries to facing the horrora of a medieval inn. The cooking and accommodation in monasterios were far saperior to those that conld be got in inns, the bread Fhiter, the beer of better quality. the foather beda in the goo ot chambers softer, the sanitary arrangements far in advance of the time. It ras as important to monasteries to attract weelthy and inflpential guests as it is to hotel companier todaj.I

- Aleo the abbeye rere one of the beanties of this realm to all men and strangers pasaing through the seme.ing Thas wrote a sixteenth centary monestio sympathiser. The monasteries were indeed houses of beanty and comfort to a weary traveller, be he noble or wanderer. They offered shelter to all who knocked at their gates. Whey loomed up as havens of refuge in desolate, out-of-the-rey pleces, where inne or other shelter could not possibly be found. The monks took upon themselves the task of opening their doors to all travellers, offering them food and lodging. Their job was a tremendous one but they performed it to the best of their ability. If for nothing else, then for the hospitality that they offered to medieval wayfarera the

\footnotetext{
1. IbId.. p. 26 .

2. F. A. Gasquet, Henry the Fighth and the Faglish Monasteries, p. 96 .
} 
monks will long be remembered.

The third activity which the religious performod was that of almgiring and charity. At the time whon the monasteries were so powerful and influential through-out fingland there were no organized charity groups or no state provision for the poor. Therefore, the monks were the only large groups who undertook to allerate some of the suffering of those who were less fortunate than themselves. During the Middle Ages the religione were famous for this work, and the beggar, like the traveller, looked toward the monastic walla as a place of help.

The philanthropic work that the monks did, came mainly under the supervision of the almoner and the infirmarian of each house. The almoner was the one whose duty it was to give what alms the house had for that purpose to the poor, while the infirmartan cared for the sick, both of the monastery itself and those who came from the outside for aid.I "According to the rule of the Aastin canons again the almoner should be 'pitiful and Godfearing -- old men who are decrepit, lame, and blind or bedridden, he should often risit and saitably supply.'"2 The monks of all orders, especially

1. Gesquet, Mongstic Ille, p. 90 .

2. Capes, op. cit., p. 285. 
the mendicant orders, helped people who were sick or in distress. "The poor, the indigent, the $810 \mathrm{k}$, the aged of the district looked to the almoner or the hospitaller for help; and whetever knowledge of simples, whotever surgical sxills existed, was to be found in the infirmarer and his helpers."l At winchester Abbey, Abengdon, and in other places also, the house supplied a hospital out of the abbey funds; ". . . but they consigted realiy of almshouses for which there were commoniy trust funds, and the infirmary of the convent did not, of course, receive sick folk from the out side." rost of the charity work of the monks was carried on by funds left to the monsstery for such purposes through the will of the founder or by endowments made by worithy noblemen. "Thus, at Moavx, among tho lists of donetions for special purposes made to the abbey, eighteen grante are mentioned for alms to be given at the gate."3 At St. Agatha' Yorkshire, similar contributions were made:

- an ondowment of fifteen shillings a jear provided one poor person with food and two poor poople with a meal on the anniversary of the death of the founder. There was in the monestery of

1. H. Ge日, The Relormation Perlod, pp. 88-89.
2. Caper, op. c1t., p. 285 .
3. Ibla., p. 286.


St. Hicholas, Exoter, 'a oertain house, oolled the "Poor Hen's Parlour" to which place there repaired daily seren poor mon before dining-time, and to every one of them was delirered on the flosh days a two-pening loaf, a pottle of ale, a piece of flesh, and on the Fridsys likewise at efternoon, as soon as dinner was done, all such poor as were tenants came, and every one of them hould have also two-penny loaf, a pottle of ale, piece of flesh and a penny in money.' 1

The charitable work of the monks consisted chiefly of making gifte or "doles" of money, food, and old clothing at the monsstery' gates to beggars, or of alding those poor poople who wore 1ll. It mat be remembered, however, that al though most of the houses did do some charitable work of this type, there was no organized system of charity among all the monasteries as a whole. The work thet each house did was accomplished independentig of the others.

The fourth activity which the religious performed was that of education. There were three groups who received their training in the monasteries: the monks themselves, the ohildren of the patron of the house and the children of rich nobles, and the poor children who were under the care of the almoner. 2

Many of the monks who were admitted to the monasterg were very young and had little or no education. Therefore, it was necessary thet some schooling be
1. Bagkerville, op. cit., p. 31.
2. Ib1d., p. 37 . 
provided for them, especially since the knowledge of Latin wes a prerequisite of promotion. ${ }^{1}$ Grammar schools were establishod in some houses, particularly the larger ones, where the young monks were taught grammar, logic, and ph1losophy. They were instructed by one of the older, learned monks. If no one could be found in the house who was capable to undertake this task, then a "secular mater" had to bo engaged.2 some zealous monks went on to the universities to pursue their studies after they had finished the monastic schools.

The second group educated by the religious were the children of the patron or of wealthy families. The houses had quite a number of these students. They camo and lired at the monastery as at a boarding school, and oftentimes they were entered at a very young ege. The abbot of Reading wrote to Iady Ilale concerning her son, Jame a Barget:

II heve set your young gentlemen with Williem Edwerds, my under-steward, that he may be well seen to by a woman for his aressing, for he 18 too young to shift for himself. He is the most towardy chlld in learning that I have knom." James' brother, George, was at Hyde $A b b e y$ by Winchester; and a correspondent of his mother was able to report that the boy is very well and profiting by his learning and that the new prior says he shall be treated by him 88 well as he ever was by the old.3

1. Cepes, Op. c1t., p. 285 .

2. Baskervillo, op. o1t., p. 39.

3. Ib1a., p. 37 . 
Most of the abbots and monks were rery interested in their young charges and paid speciel attention to their treining. Many of them worked hard and tediously with these lads to imprese upon them the thinga that they would have them learn. Frequently in the later lives of some prominent person of the Midale Ages one can discern the influence of his earlier training by some friar or monk. "This inflaonce is most clear in England, whero Grosseteste and Adam Marsh were the friends and teachers of Earl simon de Montfort, and it io not too much to say, that it was their influence which converted simon from a wild and recklese adventurer into an Bnglish petriot." 1

Naturally this educational work was not done gratis. The rich children paid a certain amount tuition to attend the monastic schools. However, it was not always certain that the houses wonld be able to collect their money. Many cases can be found where the nobles were very negligent about paying their childrens' tuition feos.

'The house of Hyde looketh for erery penny,' wrote a Hampahire clergyman to Lady IIBlo, 'To are in debt to it twent $y$ shilling (say I 30).' Lady Iislo wrote hastily to order that the prior of Hyde should be paid for the keep of her son, and the abbess of Hunnaminster for her daughter. That

1. 1. Crelghton, Historical lectures gnd Addresses, p. 110 . 
school bills of this kind were otten in arrears is shown by a complaint of the priory of Mestacre in Norfolk in 1494. 'There are many boys, sons of gentlemen, in the house, but the prior can't get the money to pay for their board and tuition.' I

The nans likewise kept joung ladies in their houses, whom they educated and trained. For the number of convents in angland, they probably did 28 mach, if not more, work of this lind then the monks did. They trained some poor girls as well ae the rioh ones. The sohooling of the young ladies differed considerably Irem that of the young men. John Aubrey, an eye-ritness at the filtshire convent said:

'The young maids were brought up (not at Hakney Sarum Sohools to learn pride and wantonness but) at the nunneries, where they had examples of piety, and humlity, and modesty, and obedience to imitate and practice. Here they learned needlework, the art of confectionery, surgery (for anciently there were no apothecaries or surgeons, the gentlewomen did core their poor nelghbours: their hands are now too Iine) physic, writing, drawing, etc.' old Jacques could see from his house the nuns of the priory (st. Mary'e near Kington st. Michael) come forth into the nymph-hay ith their rocks and whoels to opin; and with thoir sewing work. Ho would say that he had told threascore and ten: but of nuns there were not so many, bot in 211 , with lay sisters, as widorr, old maids and joung girls there might be such a number. 'This', concludes the author, 'was a fine way of breoding up joung women, who are led more by example than precept; and a good retirement for widows and grave single women to a civil, virtuous and holy life.12

Weal thy families were very thankful for the convents,

1. Bagkervilie, op. GIt., p. 3\%.

2. Gasquet, Fngligh Monesteries, p. 224. 
for aside from them there was no other place where their daughters could be sent to receive ach training and care.

The nuns also had their troubles collecting taition accounts, which were nspally in arrears. Damo Petronilla of Grace Dieu convent, in her account book (1414-1418) made an entry to the fact that, for each of the daughters of Thomas Hunter $1784 d$ was to be paid to the convent.

Lady Beaumont also had a daughter in the convent, for whom sho and her lord undertook to pay L2 138 4d a year; but when Dame Petronilla last made up her accounts, or rather in the last accounts we have Irom her pen, the nung had only got IR. Iord Beaumont, however, was evidently too great a personage to be reminded of the missing $138 \mathrm{4d}$, and the convent authoritios evidently desired to stand woll in his farour. They led him well, for instance, when he came to 800 his child; for on one ocoselon Dame Petronille gives some of the expenses of his ontertainment. These included, besides litd for 'one choulder le molton', and 8d for two lambs, an almost unique peyment for two forls for the nobleman's tablo.1

The third group educated by the larger monasteries were the poor children plaeed under the care of the almoner or the sub-almoner. These lade were taken into the house and taught, Fed and clothed at the expense of the monestery. They were trained to be ehoir-boys or "choirsters" as they were sometimes called. "Towards the ond of the Midale Ages the larger monasteries began to

$$
\text { 1. Gesquet, Monastio Iife, p. } 163 .
$$


house 'ohoirsters to sing the anthems in her honour in the Iady Chapel', in the almonry by the great gate of the monatery.wl Besides their moical training, they were given other ingtruction. "Phey were under the charge of the almoner or sub-almoner and were taught the rudimente of learning by a secular mater for term of five years at the most, for 'this period sutfices for becoming proficient in grammar." n2

These boys who recelved this freo board and instruction were very fortanate, for had the monks not given it to them they could not hare obtained it in any other way. "Rlchard Pace, the well-known Greek professor at Cambriage was a poor boy in a school which thoms Iangton, Bishop of Ninchester had established in his own house."3 The monastic establishment of conterbury College, oxford, helped meny students go on with their studies, who otherwise world not have been able to do so.

At this college there were not only the monastio atudents, bat also clertce and oven laymen who had been sent thither by the archbishop or convent of Christcharch to receive Iree quarters at the University. In all probability Iinacre, after receiving his early education at Canterbury from

1. Begkerville, op. ait., p. 38 .

2. Ibid., p. 38 .

p. 48 .

3. F. A. Gasquet, Mngland Under the old Religion, 
Sellgng the monk, was lodged at the Canterbury oxford College; certalnly the wniversity career of the celebrated Sir thomas Hore was pased there.... 1

While referring to the educational work of the monks, the glory of their old libraries might be recalled. "'A monastery without a library is like a castlo without an armoury' was an old monastic saying."2 Most of the houses had their fow collections of books stored away in various places throughout the bailding, but it was not antil the latter Midale Ages thet the large houses sterted to set aside a certain room, or part of the building to be used as a real library.

At Durham, about 1446, Prior Tessington made library, 'well roplenishod with old written doctors and other Histories and Beolesiastioal writere', to which henooforth the monks always repair to study in, 'besides tho carrelg' in the oloister. So, too, at St. Alban's, Michaol de Mentmore, who was abbot Irom 1335 to 1349 , besides enriching the presses in the cloister With books, made a collection of special volumes in what he called his study. Ihis collection grew; but it was not antil 1452 that abbot Whe thamsteds finally completed the library, which had long been projected. About the same time at canterbury, Prior Thomas Goldstone Iinishod a library there, which was enriched by the celebrated Prior Vililam Sellyng with meny procione classical manuscripts brought back fro Italy. In the same way many other religlous houses in the fifteenth oentury erected, or set apart, special places for their collection of books, whilat still retaining the great cloister
1. IbId., p. 18.
2. Gasquet, Monsetic Iife, p. 35. 
presses for those volumes which wore in dally and constant nee.1

This is not the place to discuss whether these libraries were simply storehouses of old reoords and written meterials, or if they were frequented by the monks. It is enough for us to know that they were storehouses of historical material to which many outstanding chroniclers later turned for valuable information. 2

Thus we have the medieval oloisters performing four worthwile duties for society. These services which they undertook for so many centuries were such important ones that today two of these same activities have been taken over by the otate; that of charity and that of education. If wo ungraciougly forget everything else that the monks did for humenity during their "golden age", we should bear in mind their preservation of books, chronicles, and pamphlets, which, but for their care, the modern age would have lacked. The religious took upon themelives a momentous task, and not for a fow years but for many centuries they performed their work nobly. In accusing those who were inhabiting the cloister on the eve of the discolution,

1. Ibid., p. 35.
2. Ge0, op. cit., p. 89.


al were found guilty and condemed, thelr homes destrojed and their possessions wiped out. In the farious accusation of the fer of the sixteenth centary we are liable to forget the glorious deods of the many in the preceding centuries. 
CHAPTRR III

BXTENT OF NOMASTIC POSSESSIONS II EHGLAID 


\section{CHAPTER III}

\section{EXTENT OF MHASTIC POSSESSIONS IH BNGIUND}

The dissolution of the monasterios was a vory Important tep in English history besause of the great amount of wealth and power involved. When the issae of the dissolution arose it was not a question of Whether to take fe feres of land and a pitance of money away from a group who were said to be unworthy of their trust. Instead, it concernod the possession of a large area of valuable Finglish land, plas untold fortunes in riches. If emeller amounts had been involred, perhape very little would have been said about the decay of religlous life, and still lese action would have been taken to remedy the situation. Howerer, so much land, wealth and power were connected with the monastic "soandal," that the pages of historg st111 resound Fith the query, "could not the greed for these vast possessions have been the real reason behind the dissolution of the monsstic houses?" Is it not true that the higher the stakes, the more fierce (and sometimes less honest) the fight is likely to be? Just what was the extent of monastic holdings and possessions in England on the eve of the dissolution? This question cannot be readily nor accurately onswered, 
except to say that these possessions were numerous and extensive. Many guesses have been offered, many calculations worked out, ranging from foolighly high to absurdly low Iigures. The highest estimate that I have found is thet the monasteries owned as mach as seven-tenths of all the land in fongland, whereas the lowest claims that only one-tenth of anglish soil was under monastic ownership. The following are some of the various estimates that have been made as to the extent of monastic land ownership:

Pamphlet of 1717 -- seven-tenths of whole kingdom Nesmith -- one-tenth of whole kingdom

Prof. Kovalevsky -- one-sixth of whole kingdom Old Parliamentary Rolls -- one-third or more of landed property

Ertimate made on Bve of Reformation -- one-fourth of landed property

Estimate dating from early Middle Ages -- one-third of landed property ${ }^{2}$

Yorkshire Suppression Papers -- one-third or onefifth of whole land ${ }^{3}$

Even though these figures vary they show that the

\begin{tabular}{l} 
I. A. Savine, Englis \\
the Dissolution, pp. \\
\hline $1-83$.
\end{tabular}

2. S. B. Ill jegren, The Fall of the Monasteries and the Social Changes in England, p. 15. p. 111.

3. J. W. Clay, Yorkenire Suppression Papers, 
rollgious groupg held onough land in Fngland to make them a very important factor within the country. If wo take the most conservative estimete, that of onetenth of the whole kingdom, the possession of that mach land within country would be a large share for any one group to hold. Bren the possession of one-tenth of Ingland's land makes the monasteries powerful organized anit within another organized unit, the nation. Had they owned as much as seren-tenths of all Inglish so11, then they would have been real and threatening menace to the government. This latter figure seoms much too Iiberal to be trustworthy. It is more probable that altogether the monasteries hold anywere from one-fourth to one-third of the land in Bngland. An average of the seven sources mentioned above rould give the religious approximately one-third of the whole kingdom.

In order to own this amount of a nation's land the monasteries mat have been numerous. How many religions houses were there on the British Isle before the dissolution? There were altogether about four hundred convents of won, more than one half of which were Benedictine houses and aituated in the county of York. I of the friars there were about two hundred 1. (rasquet, Engligh Monasteries, p. 204. 
houses which were divided as follows:

$$
\text { 1No. of Hovees Ho. of Religions }
$$

Pranciscans

Dominicans

Austin

carmelite

Smaller Order:

Cistercians

Benedictines

Praemonstratensions

60
53
48
36
9
200
$160-170$
$20-24$

660

472

378

288

counting the various houses mentioned abore, there were all told six hundred and thirty four larger houses scattered throughout the country, plus many smaller houser, the exact number of which we are not certain. Constant advances the reasonable estimate of eight hundred as the number of religious houses in Englend on the ere of the dissolution. 3 There wes an arerage of about ten friars to each house.

Each of these houses had not only large incomes From land and from other sources which shall be discussed later, but they also had valuable possessions within the monastic buildings. The worth of these articles can best be seon in the treasurer's accont. After the dissolntion the value of the plander that Henry's agents took Irom the cloisters was estimated according to its weight

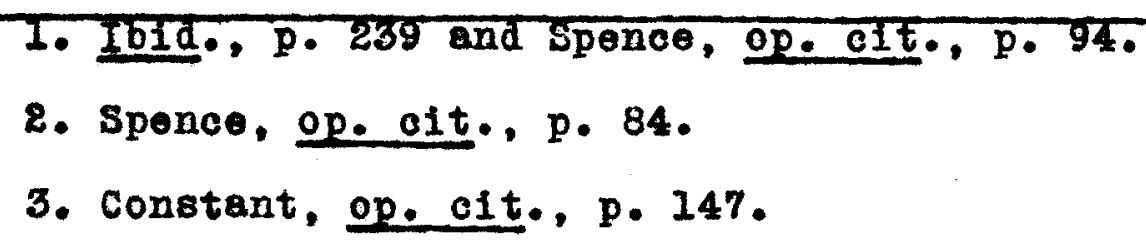


and recorded apon the treasurer's roll thas: ${ }^{1}$

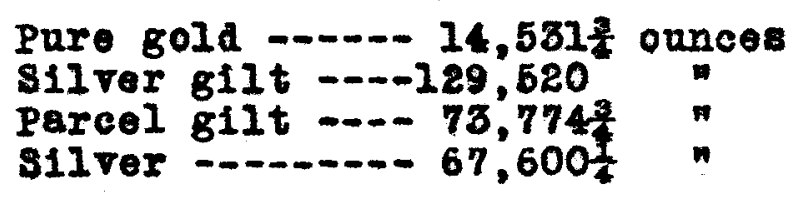

This rast collection was estimated by Sir John W1111ams to be worth in money at that dete at the melting prioe, 468,531 158 1d. To this horever, certain additions must be made. The keeper received in money for plate and other ornaments 601d at the dissolution II5,550 18 3ta and nearly I7,000 worth of plate wes forwarded to the angmentation office in the earlier jears of the dissolution. Henes the money values of the gold and silver poils actually recelved by the king and estimated only at the veighing price was more than 185,000 or rerg nearly a milition sterling of the present monej.2

The acquisition of this woalth had not taken place auddenly, but was a gradual, slow growth, which continued from century to century. It was the customary thing for a monastery to get its land as a gift or a legacy rather than through outright purchase. As lonf ago as 712, King Iuitprand popularized the praotice of w1111ng property or money to monagtic housea; ". . he permitted his subjects to make legacies to the church." 3 From that time on until 1279 large tracts or land openly passed into the possession of religions bodies, as endowmente of monesteries. The Anglo-saxon kings rould

\footnotetext{
1. Gasquet, Kagligh Monasteries, p. HI6.

2. Ibid., pp. 416-417.

3. R. I. Palmex, English Monasteries in the Middle Ages, p. 17.
} 
sometimes give entire hundreds to the monesteries.

So much land was passing into the hands of the Church

that in 1279 the Statute of Mortmain was enacted. The

Statute:

- Forbade the acquisition of land by the religloue, in such wise that the land should come into 'mortmain'. Wndowments of land were being constently bestowed on the monasteries so that the service belonging to the lands in question due to the king or other lords were for ever lost, as the persons to whom the lands were granted were incapable of fulfilling legal obligations.2

However, from 712 to 1279 the monasteries had prospered well and their lended ostates were numerous and quite extensive.

The land gifts were generally made by three groups of people. The first group might bo classed as the wealthy, pious nobles, who felt that monastic endowments were the best possible use that a man could make of his worldiy posesesions. The second group included the werlthy bat "careless." By that I mean those rich men who thought little about religion and church 11 fo during their active dags;". . get thought it well at the last to be on the side of the angels." 3 These two groups would sometimes give whole manors to a monastery.

1. Savine, op. c1t., p. 153 .
2. Spence, op. cit., p. 97 , lootnote I.
3. Palmer, op. oit., p. 17.


The third and last group of donors were the poorer people, who had little to give but would oftentimes give small portions of their land or rents.

In some instances the monastery might buy somo of its land. It has been discovered that: ". . some gifts of land were only secret sales, mortgages, and exchanges." "Host of the manors belonging to a monestery were generaliy situated in the same county as the monastery, but the monestic manore were seldom contiguous. Large monsterles possessed manor in many counties." Large and famous houses attracted more people and donors then the 1088 well known ones, and for that reason the larger ones continued to ara more riches and land into their possession. The fourteenth and fifteenth centary Finglishmen felt that he should be very careful in the choice of his religious advisor and, therelore, he usually chose a well-known monastery as his spiritual advocate. He founded his choice on the biblioal saying: "To him that hath shall be given, and from him that hath not shall be taken away even that he hath.' That 18 why Christehurch Canterbury acquired land in Devonshire and Worfolk, and Westminater Abbey acquired land in Nottinghamshire and Worcestershire."1 
Besides large gifte of land and money the ololaters were always receiving smaller donations from Visitors or gaests who might accept the hospitality of the house. From the accounts of one convent, the following incident is recorded as taking place on a cortain All Saints' Day:

Mary de Ecton, Joan Vililers, and the two danghters of Bobert Nevilie were lodged and entertained by the nuns. These visitors eventualig made an offering for the hospitality show them; as, for instance, on this very ocossion each of the Neville ladios paid 58. and Joan Vililers 6a. 8d. The last named lady was at Grace Dien no 108 than four times in the jear 1418, and each time left behind a similar offering. At another time Giles Jurdon paid 78 . for the board of his daughter during the weok of pentecost. when she probably came to visit her ister, who known al Dame Blizabeth, was a nun in the convent. Roger Boby also, who was apparently the father of Dame Allce, was entertained by the nuns twice in the jear 1416, and gave an alms of 68. 8d. at one visit and 13e. 4d. at the other.1

Fach of the religious houses had geerly income which they received from varione sources, the chlef one being the rural income from property that the monasteries owned. Monastic lands were uspally divided into two classes, demesne and tenoncies. The landed estates or monatic demesne was the least important of these two. Some hopses had no demerne at all, while of those which possessed it, demesne amounted to only one-sixth of the 
monastic property, and gave the monks only one-tenth of their rural income from land. The Income from demeane was only three-fifthe of that recelved from the tenancies. "The bulk of the monastic demesne was lessed for terms of years, and the bulk of the monastic lands leesed for years consiated of manorial demennes." The following chart shows the amounts that various monesteries received per year as their income from demesne: ${ }^{1}$

\begin{tabular}{|c|c|}
\hline $\begin{array}{l}\text { Beds. } \\
\text { Bucks. } \\
\text { Devon }\end{array}$ & $\begin{array}{l}\text { Bushmead } \\
\text { Burmham } \\
\text { Canonleigh } \\
\text { Hartland }\end{array}$ \\
\hline & $\begin{array}{l}\text { Iantony } \\
\text { Winchcombe }\end{array}$ \\
\hline $\begin{array}{l}\text { Hereford } \\
\text { Hants. }\end{array}$ & $\begin{array}{l}\text { St. Gothlac } \\
\text { St. Neots } \\
\text { sartre }\end{array}$ \\
\hline Rent & $\begin{array}{l}\text { Dertford } \\
\text { Horton }\end{array}$ \\
\hline $\begin{array}{l}\text { Lanc. } \\
\text { LeIc. }\end{array}$ & $\begin{array}{l}\text { Furness } \\
\text { Garendon } \\
\text { Kirby Beller } \\
\text { Launde } \\
\text { St. Nary } \\
\text { Uiveracroft }\end{array}$ \\
\hline Iinc. & $\begin{array}{l}\text { Ailesham } \\
\text { Groenfield } \\
\text { Hagnaby } \\
\text { Markby } \\
\text { sirhill } \\
\text { Spalding } \\
\text { ford, St. Mi oheol's } \\
\text { Swinesherd }\end{array}$ \\
\hline $\begin{array}{l}\text { Norfolk } \\
\text { Horthante }\end{array}$ & $\begin{array}{l}\text { Iangley } \\
\text { Abhby } \\
\text { St. Indrews } \\
\text { St. James } \\
\text { sulby }\end{array}$ \\
\hline
\end{tabular}

$\begin{array}{rrr}I & 9 & d \\ 10 & 0 & 0 \\ 11 & 0 & 2 \\ 1 & 16 & 0 \\ 45 & 0 & 0 \\ 32 & 9 & 3 \\ 142 & 1 & 8 \\ 0 & 13 & 8 \\ 20 & 16 & 8 \\ 33 & 6 & 4 \\ 26 & 18 & 4 \\ 5 & 0 & 0 \\ 104 & 15 & 8 \\ 44 & 7 & 8 \\ 14 & 0 & 0 \\ 113 & 0 & 0 \\ 41 & 0 & 0 \\ 18 & 6 & 8 \\ 9 & 0 & 0 \\ 12 & 13 & 0 \\ 32 & 0 & 0 \\ 19 & 0 & 6 \\ 26 & 13 & 4 \\ 50 & 0 & 8 \\ 9 & 14 & 7 \\ 46 & 7 & 4 \\ 20 & 8 & 0 \\ 31 & 6 & 8 \\ 17 & 0 & 0 \\ 13 & 10 & 0 \\ 133 & 6 & 8\end{array}$




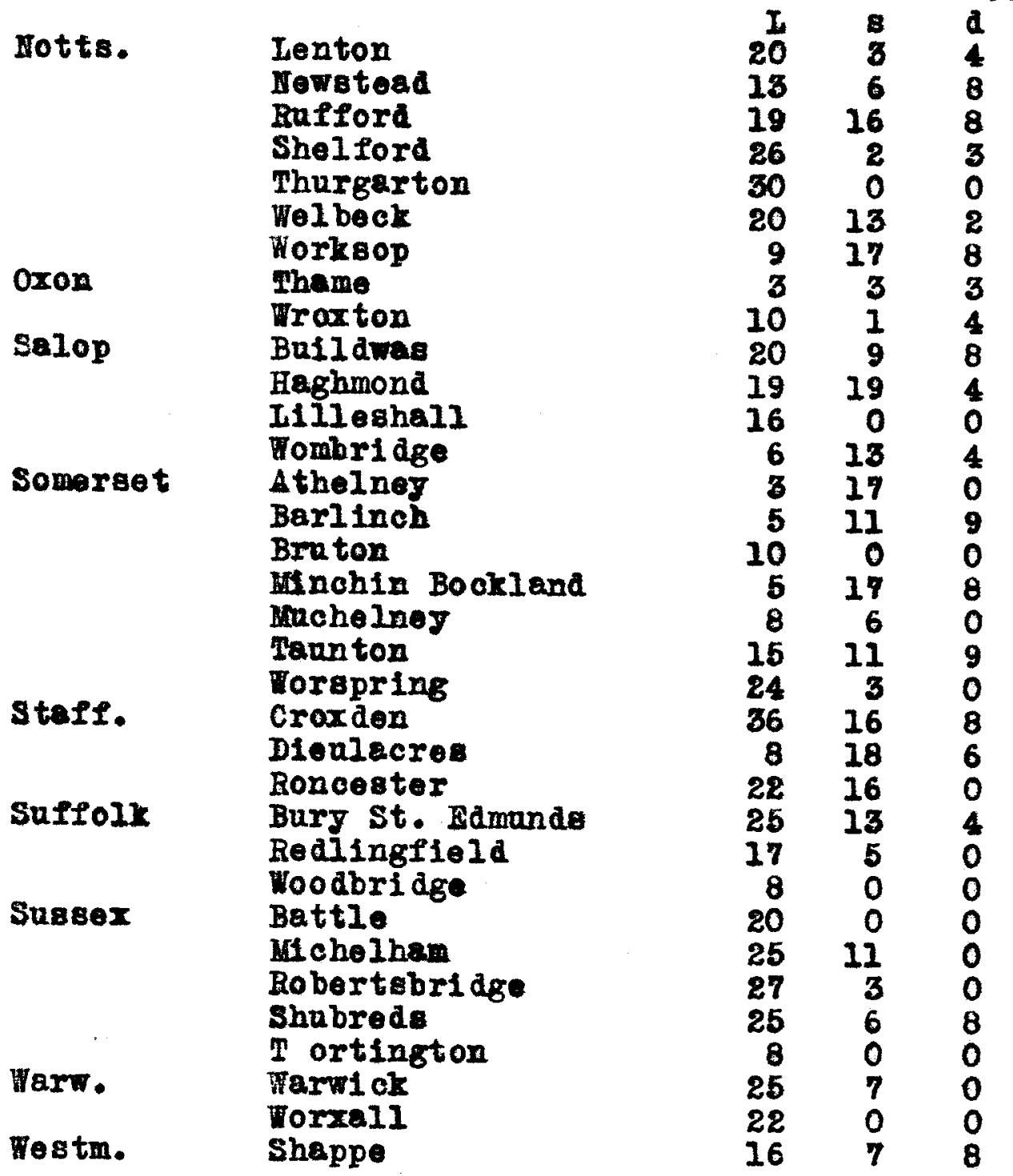

The most important part of monastic property and that which jielded the most income was the land held as tenancies. The rent from this land was paid in money and labour, or in the performance of certain duties, according to the amount of land held. From the Rentalia and Custumaria of Glastonbury examples can be found of. the different types of pryments that the tenants had. 
4 cotter with Iive acres of arable land paid $4 d$ Iose I farthing for rent, and Iive hens as 'kirkset' If he were marriod. From Micholmas to Midsammer he was bound to do throe days lobour a roek of farm work on the monsetic lands, such se tolling on the fallows, winnowing corn, hedging, diching, and fenolng. During the rest of the year, that is, in the barvest time, he had to do five days work on the farm, and could be callod upon to lond a hand in any kind of occupation, excopt loading and carting. Ilke the farmers he had his allowance of one sheaf of corn for each acre he reaped, and a 'Iareroc', or as mech grass as he coula gather on his hook for every acre he mowed. Bealdes this general work he had to bear his share in looking after the vineyead at Glastonbury.1

Another example is given of a emaller tenant. "A cortain Allce. . had one-half an acre field for which she had to bring water to the reapers at their harvest and sherpen their sickles for them." 2 on the other hand, there were tenant s wo paid rather high rents. Dame Petronella of Grace Dieu kept an aceount book for the yearg 1414-1418, in which she recorded the rent from a farm at Belton as L2I 178 9d: ". . this being the largest item in the receipts, and indeed a very large item in those days from any farm rent." 3

The monsetic tensits were apparentiy well treated by their landlords. Records have been found of "common meals" which were prepared for the tenants when they

1. Gesquet, lonabtic Iife, p. 19\%.
2. Ibid., p. 198.
3. Ibid., p. 161.


worked on the common land and provision was made for a common Christmas meal and entertainment shared together in the great hall. "They [the tenante] Iurnished the great Yulo-log to burn at the dinner and each one brought his dish and mug, with a napkin if he wanted to eat off a cloth'; and still more curiously, his own contribution of firewood that his portion of food might be properly cooked. $n^{1}$

Whenever the tenante were required to work over the time allotted them for their landlords work, at taske such as harreating, shoaring, etc. they were paid extra. In Dame Petronella's accounts, the following examples can be found where tenante have been revardod for extre services that they have performed:

In the lambing season, for instance, Henry, the shepherd, was given 2d 'for his good service and care ot the shoep', and John Stapulford recoired the same an 'for looking after the lambs before the1r weaning', whilst John Farren for 'foldhurdling' was rewarded with 1s; and to take another in tance of a somewhat different kind, the convent ballift at Kirby, one Richard Marston, was given a puree, as a sign thet the nuns appreciated his care of their property. one chance entry shows that when the aheep were belng sheared, the labourers were given extra meat for their meals, since Deme Potronella give 16d for a calf to fied them spocially, on a day whon eridently she and her sister in religion were eating tieh in the convent refectory. 2

$$
\begin{aligned}
& \text { 1. IbId., p. } 198 . \\
& \text { 2. Ibid., p. } 172 .
\end{aligned}
$$


Gasquet, after citing such cases, refers to them thus: ". . numerous instances of the kindly consideration extended to their tenante by the monastic proprietors, and the relation which existed between them in reality more that of a rent-charger than of absolute owners." 1

Although the monks were not supposed to engage in business enterprises they had certain activities on their estates for the bonefit of their tenants from which they received a certain income. They were not actively engeged in indestry and in most cases the income from this source was small. In the commissioners" report, mention is mado of tanneries, tileries, milla, and bakeries. "A bakery is mentioned in the monastery of St. Heote, Hunte; it is called a 'general' bekery and it is possible that it was an ancient seigniorial oven. illeries were owned by the monastery of St. Augustine, Canterbury; Christchurch, Canterbury; and Battle."2 However, the monaterie日 had quite a number ot mills, eopecially corn mille, from which they received a considerable amount of money. It hes been estimated that the income Irom mills was $2 \frac{1}{4}$ per cent of the gross

I. Ibid. p. 200. The ocolesiastical landiords cannot be given all the credit in this regard, for similar customs were followed by some of the lay landiords.

$$
\text { 2. Savine, op. cit., p. } 125 \text {. }
$$


temporal income. ${ }^{1}$ Following are some examples of the income from the mill as compared to the gross temporal income: ${ }^{2}$

$$
\begin{aligned}
& \text { Vardon (a) } 141013 \mathrm{~s} 4 \frac{1}{4} \mathrm{~d} \text { grose temporal income } \\
& \text { (b) } 371384 d \text { income from mills }
\end{aligned}
$$

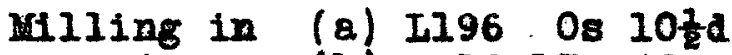

$$
\begin{aligned}
& \text { Kent (b) } 19178 \text { 4d }
\end{aligned}
$$

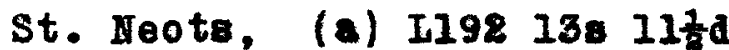

$$
\begin{aligned}
& \text { Hunts. (b) } 24 \quad 38 \text { 8d } \\
& \text { Rufford, (a) } 11861384 d \\
& \text { Iott8. (b) } 31688 d
\end{aligned}
$$

Prom sixty monesteries: ${ }^{3}$

Gross temporal incomo n............ I 23,000

Total income Irom mills of 60

monasteries -

Revenue from mills -...- $2 \frac{1}{4} \%$ of gross temporal incom

nother source of monastio income, and one of the most interesting phases of monastic lifo was the granting of corrodies. There were two types of corrodies granted. The first type might be called an annuity plan or a provibion against old age. It was used by the monasteries whenever a religlous house was hard pressed and in need ot ready cash. If a man wanted to make certain that he and his wite were provided for in their old age, he would
1. IbI0., p. 12\%.
8. Ibia., p. 127.
3. Ibia., pp. 126, $12 \%$. 
pay to a mostery a lump sum of money. In return the monastery guaranteed to make certain provisions for this person after he retired from active 11fo. These corrodians were referred to as pensioners.

heoords have been found of many interesting ceses where corrodies were granted. At Thetford, in return for the payment to the convent of 130 mariks, a certain Dr. Nobys was to recelve annually for the rest of his Ilfe five merks, the use of a stable for two horses, house to store hay, two rooms for himself, and the use of the monastery's garden. The doctor had it arranged so that if the convent defaulted and he did not recoive his annual five marks, ho had distraining power on any two of the convent's manors. ${ }^{1}$ similar case was found at st. Swithun'a, Tinchester. "A peneioner paid 50 marks for certain allowances of food and clothing, and bound himelf to give the convent the benefit of his services as physicien."n2

Mr. and Mrs. HAtohell at Ford $\triangle b b e y$ were to have yearly 8 marks (I 150 nowadays), a house and garden, bread and ale from the monastery bakehouse and brewhouse (far better than they could have got at an inn) and a pottage of fish or flesh 'as much as two of the monks of the monasterie receive."J

1. Palmer, Op. cIt., p. 18.

2. Capes, op. eit., p. 293.

3. Baskerville, op. cit., p. 66 . 
In the Compotus Rolls of st. Swithun's priory, Winchester, sereral cases of pensioners are mentioned. The first mention of a corrody seems to bo in the Hordarian's Rolls 1327-1334.

The convent granted F1111am of Iilleboune in Normandy a Corrody of IIO in money, a Robe 110 ol18 of oloth), 2 fur 8 and 2 capes of Budge, 3 loads of hay, 2 of strar, 3 quarter of oats, and 2 cartloads of bruehwood, in return for a Messuage, etc, at Drayton in Barton stacey parish, a 'Gurges' or fishpool on the river, 3 aores of meadowland, a pasture, a small 'place' or plece of open land, and a virgate of land in Drayton. In retum iny lord Willam enjojed the above rent for the rest of his life, that is, for about eight jears. 1

Another case is cited from the cathedral Records, Ho. 147:

In 1330 Alezander Herlard the prior granted Richard Becke a Corrody of one conventual loaf, and one pot of conventual beer daily. In retura for I50 sterling paid down to the monssterg. 2

Prior Alexander Heriard in 1348 on receipt of 160 bound himself to Andrew Haywode and Allce, wife of Ralph Rassel, promising to give Andrew a robe with fur or 208., and to Alice and her son John one 'Mfiche' loat and one white loaf, called 'Whitchin', and one 'just' or pot of Convent beer daily for her life-time. 3

The following examples of corrodies are found

in the Yorkshire Suppression Papers:

Prions, p. $159^{\circ}$.

2. Ib1d., p. 159.

3. Ib1d., p. 162 . 
Arthington -- Benedictine or Clunisc Iunnery

Paymont of annulties of 268. 8d. to Leonard Bekwith, Brq., 20s. to John Riddjall, and 268. 8d. to Robert Arthington and his brother Lawrence, with pensions to the nuns, and with 338. 4d. to Margaret Mormewell for a corrody. (Hinisters" Accounts, 4644)1

Charter House -- carthusian Priory

40s. to John Swyfte for a corrody. (Ministers' Aco ounts, 4644) 2

Fendale or Grendale -- Benedietine Funnery

Annuity of 408. to Thoma Henryson, Chaplain. (Ministers' bocounts, 4644)

Old Walton -- Gilbertine Priory

L8 198. 8d. For corrodies to William Gascoigne and Agmes his wife, Thomes Norman and Agnes his wifo. (Ministers' 'iccounts, 4644)

Thickhead -- Benedictine Funnery

538. 4d. for a corrody to Henry T11kynson, Chaplain. (Ministers' Accounts, 4644)

Milberfose -- Benedictine Abbez

56s. for a corrody to Idyard Harlynge, Chaplain. (Ministers' Accounts, 4644) 6

1. CIE. , Op. CIt., p. 92.

2. Ibid., p. 120.

3. Ibid.. p. 121.

4. Ibia., p. 132 .

5. Ibid., p. 161.

6. Ibia., p. 167. 


\section{Yedingham -- Benedictine Nunnerg}

33. . for corrodies to John Pykerings and Agnes his wife, Richard Dobson and Kand his wife. (Hintsters' Accounts, 4644) I

The second type of corrody was that which the King or other petrons of monasteries were entitled to grant, and it was given as a reward to a faithful servant who was no longer able to work. The patron felt free to send ang old retainer there with orders for the monastery to take care of him. Then one died, there was always another sent in his place, so that the monasterios usually had one of the king's servants to take care of.

Howadajs retired generals and admirals, civil servants and the like, draw thoir pensions and live whe re they will. In the liddle Ages it was far less expensive to send them to a monastery, there to receive maintenance, food, clothing, shoe leather, firewood, and chamber within the enciosure of the abbey for their residence. Fach monastery was bound to keep one or two of these old gentlemen. They must have been a great nuisance.2

This practice brought no profit whatever to the house, but was instead a burden to it.

When a patron made demands of a monastery, they could not easily be refused. However, when corrodies were asked for the servants of bishops or noblemen to whow the monks felt no obligation, the requests were
1. Ibla., p. I/1.
2. Baskerville, op.cit., p. 65 . 
often rejected. Such was the case in the following instance:

Bishop of Iichfield demanded a corrody for his cook, bat Peckham would not let the Prior of Tutsbury in Staffordshire consent to it. Bven the high-minded Grandisson of Ineter made the same demand at Iauncester for his own servant.1

It has been found that in most cases the monks were the 10 sers in the transaction of granting corrodies, for they were forced to pledge the resources of the futare to raise small sums for the present, whioh were not always spent to the best advantages. This practice not only brought ruinous results finencially to many houses, but also wrecked the routine of the inmates daily lives. Eapecially, in the smaller housea the presence of a few boarders, with their tastes for fine and laxarious things, their stories of the outside world, their amusements, etc. upset the ascetic life of the monks. Ralph of Shrewsbury, Bishop of Bath and Wells was shocked at the "fine beds and costly ressels" that the pensioners at Mrochelney required. 2 Then the bishops made their visitation they insisted that the practice of granting corrodies should be stopped. 3 From all that has been said it can easily be

1. Caper, op. c1t., p. 295.

2. Ibid., p. 293.

8. Ib1a., p. 293. 
real1sed that monastic property and possessions in Fngland shortly before the dissolution were far-reaching and would stand out as a very tempting and rich prize for anyone who wight dare to dream of gaining control of thom. The annual revenue of the eight handrod English houses would be a nice little oum to add to any king's treasury. Tro differont ostimates have been wade comparing the national income from land with that of the monasteries in the sixteonth century. Pamphlet of 1717:1

Wational income from land -...-----20 millions Income from monastic lands -...-.--14 millions Nesmith: 2

Hational income from land -..-.-.--20 millions Income from monastic lands -......- 2 millions Unfortunately we do not have the total national income for the year 1535 and are therefore unable to compare the total monastic income with it. Howerer, there are several reliable estimates of the total monastic income for that jear:

I. Grose revenue Irom all church property -......................... 320,280 108. Revenue from the monsiteries -... I 150,000 or 200,0003

1. Sarine, op. cit., p.81.

2. Ibid., pp. 82-83.

3. Constant, op. cit., p. 148. 
II. Net income of the monsateries -......- I 136,361 188. 8d.1

III. Annual monastic income-- I $200,000^{2}$

IV. Annual monastic income-.- I 171,312 48. $3 \mathrm{~d}^{3}$ Most historians take the most liberal Pigure, that of I 200,000 as the annual income of the monastio houses. Iord Herbert has rentured to anggest: "The monastic income amounted to one-fourth or one-third of the national income."4 Not knowing the exact amount of the national income it is hard to tell whother this calculation is trastworthy or not. However, assuming that I 200,000 a year was the income of the eight hundred houses in England, regardless of what the national income might have been, this an gerves to show the wealth thet had accumalated in the hands of this oloistered group through the centuries of England's history.

Thus on the eve of the dissolution there were -ight hundred or more monsstic houses in England, each possessing its own lands, its own wealth, its own power and prestige, and its own influence both in the district

I. Savine, op. cit., p. I00.
2. Gasquet, English Monasteries, p. 387.
3. Ibid., p. 387.
4. Savine, op. cit., p. 87.


In which it was located and throughout the nation as well. These eight hundred houses owned from one-third to one-fourth of the landed property in the nation, shared an annual income of at least I 200,000, not counting the rich possessions they had such as restments, gold and silver plate, ornaments, otc. "All told the monastic property must have been worth some I 50,000,000 of our money."l They were undoubtedly a very powerful group within this rising modern state. It is not difficult, therefore, to understand how a king "who ruled as woll as rolgnod" might hare dreamed of how he might strengthen his rule without this religions force within the nation and of the added power, riehes, and lands which would be his, thereby making him "the richest king in Christendom" if only he dared to make his dreams come true. 


\section{CHAPTER IV}

IITERPKRERCRS IN MOMASYIC IIHE 


\section{INPERFERENCES IN MONASTIC IIPE}

In spite of the fact that the monasteries possessed great wealth, moh land, and had extensive influence throughout the countrgiide, they were not always Iree to rule their domains as they plessed. They were theoretically free institutions, but actually many people claimed the right to interfere in their cloistered life. The peaceful colitude inside many cloistered walls was shattered by the worldiy olamor of "ontsiders" who professed right to modalo in their affairs.

This "right to meddle" dated from years past and most monasteries resented it. In some cases the interference in monastio life was necessary, in others the monasterles would have prospered more had they been left to manage their own affairs. Whether this interference was beneficial or not, it is necessary to remember that the sixteenth century monsistery was not the secluded place it was supposed to be. Many people claimed the right to dictate the policies of the religious houses and to select their own candidates to I1Il vacancies. This outside interference mat have had some influence on monastic life, probably causing more harm than good. 
There were two different types of interference in monastic Iife, lay and ecclesiastical. The first to be considered are the different kinds of lay interference that the religions had to tolerate and which at times mut have proved very trying to them. The founder or patron of a monestery was the most important of the lay group who interfered. The founder of a religious house took upon himself certain obligations which he was supposed to fulfill. In 1373 John of Gaunt, Duke of Lancaster, wrote:

'I am bound -- as adrocate of the house of holy religion of the nuns of Nuneaton to give succonr and help to the said nuns, and their goods and chattels, that they may servo God in peace and quiet according to thoir foundation and the rule of their religion." Protection, however, entailed right of interference.1

The original founder of a religions house transmitted to his descendant 8 , who thereafter were known $a 8$ patrons, the same rights as ho himself had shared. If the members of a founder's family died out, the right of patronage was not allowed to stop. It could be transferred from one family to another as a grant from the crown, or it might oven be sold.2 Therefore, death did not promise the removal of this source of lay interference, it ondured for generations, in fact as long as

1. Beskerville, op. elt., p. 46 .

2. A. Esquiros, Religious Iife in England, p. 14. 
the monasteries themselres.

It would be unfair to say that the monastery received no benefits from the patron, except his promised protection. There were certain thinge that a patron could do for the house whose patronage he onfoyed, such as aiding the religions to get around the mortmein 12 and and thus increase the size of their estates, or to hasten the transaction of their business through the courte. ${ }^{1}$ The patron also looked efter the financial interest of the monastery. Whenever the chance presented itself, the patron was certain to use what influence he had at court to farther the interests of his house.

Whatever services the patrons did perform for their houses they expected some remaneration in return. Oftentimes the payments were greater than the services rendered, frequentiy proving a burden to the smaller houses. One service that the patron expected from the oloister was that of hospitality. Brery monestery had a lodging especially for the founder, where he and his family might come and stay for long periods at time. It is not cortain whether all monasteries allowed the women of the patron's family to viait with them, bat 
cases have been found where the ladies were permitted to stay at some houses.

The Archbishop of York allowed the patron's wife to stop one night and one night only at Hewburgh Priory. On the other hand the Dake of suffolk and his wife, Queen yary, sister to Henry VIII - seem to hare epent weeks at a time in the grest Angugtinian house of Butley near Ipswich. The Queen used to have picnic suppers in the canons' garden daring the hot weather.1

These extended visits were undoubtedly great expense to the house. The great claniac priory of Thetford ras reported in 1879 as being crippled by the residence there of the adrocate (the Barl of Norfolx's brother) who cost the house more than the whole prior and convent." 2

Besides the right of hospitality, the patrons expected other services Irom the monks. While alive they had the first claim to the prayers of the religions, and required prayers ald not only for themeelres, but elso for their decessed ancestors. Lfter death they had the right of burial in the choir of the charch, plas the seying of more prayers for their departed soul. Horeover, If a patron felt that all was not as it should be within his house, he conld demend a visitetion, and have superiors removed from office. "The Barl of karch', wroto Blahop Spofford of Hereford to the canong of Chirbury in 1423 ,
1. IbId., p. 49.
2. Ibid., p. 5I. 
'complains, as patron and founder, that his priory 1s In state of collapse. duties force mo to get the present prior out and have another elected."nl If the patron was a consolentious leader, really interested in the welfare of his charge, then this power to demand a visitation was a good weapon for him to have. However, in many cases this right of patronage was used for selfish ends rather than beneficial ones. Superiors could be worried into resignation if the patron wanted them removed from office so he might put ono of his favorites in thoir place.

The monks were acarcely ever allowed to forget their founder, especially when a vacancy occurred in the monastic ranks. Before the place could be filled the permission of the patron had to be sooured. It was almags almost certain that the election had boen "fixed" beforehand, as the patron novally had some preference in the affair. Such was the case of Lord Dacre when he wrote to the Prior of Lanercost in Cumberland.

'As I am your founder', he wrote to the convent, 'and bound in conscience to see to your welfere and give unto you folthiul counsel, please go to the chapter house and elect a sub-prior to look after the internal affairs of the house. What about Canon Richard Halton? I know that he has some obstinacy, but by the help of the Holy Ghost he is virtuousiy roducod of his own good mind and my

$$
\text { 1. IbIa., p. 52. }
$$


singular pleasure, content and consolation. In w opinion you would do well to elect him. I em your founder, and se far as in me 18, ascent to his election. You had, therefore, better eleot him without any obstinacy or grudge as you intend to plesen ma. There was not much doubt about the moaning of this letter and, considering thet the priory was almost at the gates of Iord Dacre's castlo at Naworth, it is scarcely to be supposed that the canons withstood their founder's wishes. 1

Whon a vacancy occurred at Croxton Abbey in

Leicestershire the founder immediately took advantage of the situation.

Lord Berkely who was founder of the Premonetratensian abbey at Croxton in lelcestershire, took the extreme course of occupying the abbey the day before the election in 1634 and telling the abbot elect that unless he $\mathbf{T 1 1}$ pay $L 500$ (III0,000 to 15,0002) another abbot would be elected at the patron's pleasure. 3

The deily routine of monastic life was interrupted by still another group besides the patrons, namely the corrodians. Although they hed no power to interfere in the affairs of the house, such as the patron had, they were "outsiders" who were used to living in a different atmosphere, having different tastes, amusements, posseseion, etc. than the "regular" clergy. Some of the older pensioners must have been terribly boring, if not annoying while others, with their expensive idess and

1. IbId., p.5I.

2. Equiralent in 1937 .

3. Beskertille, op. cit., p. 53. 
fascinating tories of the world outside, probably created an air of unrest and discontent within the cloister. The discipline problem was much harder for saperiors who had these pensioners to contend with. The secluded life was not as it should have been when these "boarders" were permitted within the monks' home. The thira source of lay interference in monastic Iife was the Crown. The king remeined the most powerful patron in the land, many being the houses of which ho was founder. Besides interfering in the life of the religious in the ways in which the other patrons did, the king kept "his" abbots busily engaged transacting his business, while their own suffered from neglect. Iumerous jobs were found for them, duties such as magistrates, cormissioners of the peace, collectors of revenue, survejors of rojal estates and forests, and game-keepers. 1 In fact, they proved to be such remarkable game-keopers for the king that when a racaney occured at the wealthy Beauliea Abbeg in 1533, Sir William Fitzwilliam recommended the abot of Waverly for the position because he had been a very proficient keeper of the king's game.2

Iike all other patrone the king also medaled

$$
\begin{aligned}
& \text { 1. Ibld., p. } 69 \\
& \text { 2. Ibid., p. } 69
\end{aligned}
$$


in the election of the abbots and priors. He interFered even more than others since there were so many houses of royal patronage. It was the usual procedure for this right of interference to be in charge of the king's chief minister, at least such was the case during the reign of Henry VII. And it might also be mentioned in passing that the chlor minlater did not consider himself too good to stoop to bribery in atiairs of this nature. There are numerous cases where the minister, especially wolsey and Cromwell, was personally enriched by the promotion of a certain candidate.

'Wo have elected John Bradley as abbot', mrote the convent of Milton, Dorset, to Wolsey, in accordanee with your letters.' 'Letters' of this kind were not to be disregarded. The only stipulation that the monks over seemed to make was that the Crown should appoint one of their own number and not a stranger. But even so they never seem to have refused to elect the royal nominee any more than the chapter of WeIls in 1526 ion recept of the Cardinal's letters,' refused to elect one Thomas Wyter as Dean at the next racancy. The racancy occured in the Iollowing year, and the new Dean was Thomas Wynter. How Thomes Hyter happened to be the Cardinal's son, boy in his teens.1

The women of sixteenth century Englend were not to be outdone. Many wealthy, intluential ladies saw to it that they had their chance to modale also, and some of the worst trouble that the monasteries had was caused by the interference of these ladies. They were especially 
active in the capacity of appointing abbots and priors and the records of many houses show that auperiors were oftentimes elected through the influence of some prominent woman. Following are examples of two such cases:

June 14, 1425. Iondon. He [bishop] instituted Sir Thomas Hardy, chaplain, as rector of the pariah church of Brakley, vacant by the resignation of Sir Simon Belton; at the prosentation of the lady Joan de Beauchamp, lady of Bergevenny.1

July 18, 1428. Iondon. He instituted Sir John Bowlegh, ohaplain, as rector of the parish church of Mysterton; at the presentation of Anne, countess of Devon. 2

Anne Boleyn and her Bister, Lady kary Carey, were always interfering in monsetic affairs. This was not done for the sole purpose of placing a favorite in office; they usually were benefitted flnoncially; for instance, Lady Mary Carey recelved an annulty of one hondred marks a year from Tynemonth priory because she was influential in getting a certain stongwell elected a. prior. But in April, 1537 Prior Blakeney, the successor of Prior stonywell, wrote to Cromwell:

'. - the lady can now demand no such annulty, 88 she can do no great good for me and my house.' In other words she had now no influence, since her sister, Anne the Queen, had by now lost her head. 3

\footnotetext{
1. T. S. Holmes, Register of John Stalford, p. 30. 2. Ibid., p. 62 .

3. Baskerville, op. cit., p. 67 .
} 
In cases where the patron of a monastery was a lody and her wishes were not obejed in matters of election, revenge was swift and certain. Such was the case of the countese of oxford. Unbeknowst to the lady, one of her favorites was remored from oftice by the Bishop of Iondon in 1395 and a new officer installed in his place. When the Countess learned of what had happened he took immodiate action.

Directly she heard of the proceedings, she flew into a violent rage, collected a party of armed men, broke into the priory by night and carrled off the intruding prior, clad only in his pyjamas (or Whatever answered to them in those dajs), shut him up in her private jail and only released him after he had sworn by the Host to trouble her no further. The lady won the case.1

The other type of interference under which the monasteries languishod was ecclesiastical interference. Varione eccleaiastical personages had authority orer the houses and could medale in their affairs if they so desired. The bishop of a diocese had charge of seoing thet the discipline of the houses wes in order. In osse the office of bishop was vecant, then the archbishop carried out the duties until the place could be filled again. Besides the bishop and archbishop, a papal legate such as Wolsey, or a royal visitor as Thoma Cromell could pry into the monks' affairs.2

$$
\begin{aligned}
& \text { 1. IbId.. p. } 53 \\
& \text { 2. Ibia.. p. } 73
\end{aligned}
$$


These visitations were the interruption which the monte dreaded most. Visitations were supposed to be hold at least once every three years. Although the bishop possessed this power he was very restrained in the work that he could do. For inatance, he could not visit the Cluniac, Carthusian, Cistercian, Premonstratensian, Gilbertine, Pranciscan, Dominican, Angustinian, Carmelite, and the greater Benedictine houses. These bodies enfoyed freedom of opiscopal jurisdiction, while those who were foroed to submit to it were continually causing trouble, either trying to exempt themselves, or refusing to admit the visitors when they did come. For example, the dispute betweon Hilary, bishop of Chickester and Walter, abbot of Battle abbey was due to the abbot's attempt to escape visitation.

The abbot pleaded exemption from the jurisdiction of the biehop, by virtue of the charter granted by Viliam the first, thoir founder: and this dispute being brought before the king, the abbot's pretences falling in with the interest of the prexogative, Stephen, who was incensed at the conduct of the bishops towards him, declared the abbey a royal chapel, and took it under his own immediate care. This dispute succeding in this manner, the religious began everywhere to find out pretences to exempt themselves from the jurisalction of their bishops; more especially the ancient abbeys.1

Bishop Grosseteste thought that it was a bishop's duty to visit every house in his diocese. The religions

I. Warner, op. cit., p. 338 . 
had different views on the question. Because

Groseteste continued to feel it his duty to carry on the risitations, he began a six years' foud with his own house besides involving himself in quarrels with numerous other monastic houses. 1

The monks resented the bishop's right to risit them so intensely that they seized upon any pretense to exempt themselves. Wenty-two years before Bothe became Bishop of Hereford, he rorked as commissary of Bishop smythe of Lincoln. In the year 1500 the bishop prepared to visit a religious house in his diocese, but was delayed by urgent business of state. Howerer, he sent Bothe on ahead with orders to start the visitation for him. The house, claiming that only the bighop himself, and not his comissary, had the right to visit them, refused Bothe admittence and he was forced to withdraw. 2

Bron after bishop had made his visitation and attempted to correct some of the abuses that he found In the monastery, the monks would again try to show their desire for independence. The bishop might order thet certain things be done after his visit, bat many

\footnotetext{
1. Pattergon, op. c1t., p. 133.

2. A. T. Bannister, Begister of Charles Bothe, p. $\nabla$, footnote 1 .
} 
times he had to inroke the help of the king's minister, or of the Crown itgelf, before his orders were obeyed. When the Bishop of Iondon visited Spalding priory he encountered this trouble. He found that the prior was too easy-going and that the house was becoming notorious for its lack of discipline. He wished to replace the prior by a stern disciplinarian whom the monks feared. The prior and the monks had other ideas. Thereupon, the blshop was forced to write to Wolsey for help. "I can't get the Prior of spelding to resign,' wrote the Bishop of London to Wolsey, 'though all legal means have been tried.inl

There were some cases where the bishops were too occupied with matters of state to get around to supervising the monateries. Henry VII, like his father before him, believed in having the bishops attend to much of the state's business, thereby getting their work done at the Church's expense.

Whilat many of the bishops and other ecolesiastics were thus continualig occupied in civil business, it was impossible that the people at large could really regard them as the actual pastors of their souls, responsible for each of them.2

Thus, fel hours were left for the religlous to attend to their affairs and almost no time for visitations.

\footnotetext{
1. Bagkervillo, op. cit., p. 18. p. 51 .

2. F. A. Grsquet, England Under the 0ld Religion,
} 
In case a bishop continually neglected the houses in his diocese, the patron or nolghbors could, and did, often petition the king for a visitation. Ueually before this stop was necesary the archbishop had intervened and taken charge of the neglected affairs. Th1s was done in the case of Richard Hix, the Bishop of Norwich. "The bishop's diocese was now in such disorder that the archbishop instituted a visitation of that see."il

The monastic houses, therefore, were not left entirely to their own but were subject to many interruptions in their affairs. Of the two interferences, 1t reoms that that of the ecclesiastics cen be more justifled than that of the laymen. The lay interference was more of a celfish nature, where the founders, patrons, nobles, Crown, eto. Interrupted not 80 mach for the benefit of the houses, as for their own personal aggrandisement. On the other hand, the ecclesiastical interference was not so mercenary and far less personal. If this supervision could have been carried on by the right sort of men, free to attend only to religions affairs, it seoms that it would have been a good thing for the monasteries. It wonld have served as a restraining

p. 41. 1. J. Stype, Memorials or Thomes cranmer, vor. ${ }^{\text {, }}$


influence on the monks who were tempted to break their rors. Because of these people who had the right to medale in their Iife, the monks may have made mistakes, which left to themelrea they would not have made; for example, these difficulties were evident when the petrons were permitted to "elect" those whom thoy desired for superior positions. Meny superiors, thus elected, were not competent enough for the post which they were to fill; whereas had the cholce of superfors been left to the derout monks they probably conld have chosen a more capable leader.

Mang times we are prone to judge too quickly and too rashly those who cannot defend themselves. Often we place the guilt on those who were present at the acene of the crime rather than trouble ourselves to look elsewhere for possible suspects. Could it be that the primary cause of some of the faults that we lag at the feet of the monks and nuns might more jastly be placed at those of these "outsiders" who took it upon themselves to tell the religlous how to "run" their cloistered Iife? 
CRUPTRR V

BRRAKDOWN OF WONASTIC IDEAIS AND PRACTICES BEFORE THE DI SSOLUTION 


\section{CHAPTER V}

\section{BREAKDOWN OF MOHASTIC IDEALS AIND PRACTICES BEFORE THE DISSOLUTIOII}

In the early daya of monssticism certain rules and ideals were set up by which those who chose this mode of Iife were to live. These aims were constantly kept before their attention and they strove to measure up to the standarda established for them by their pious forefathers. These silent, cloaked figures hurried about their work with an admirable zeal, never losing sight of the ends to which they had dedicated their Iives. This life of theirs was simple, exceedingly so compared to that led by those who followed them many centuries later.

In the beginning the monks had no property, possessions, or riches. They owned little of this world's goods, and with what they had they were contented. It was easier for them than for their followmen to live closer to God, for they had no morldly treasures or intereste to distract their devotion. Their habits, homes, food, clothing were poor and simple, and so they were able to live up to their ideals: As the jears passed and as the emollment in the monestic army inereased, the very nature of that life changed. It glowly ovolved from the aimple, crude routine of the 
early days, to the weal thy, highly organized structures Which covered the land on the eve of the dissolution. one might gather from the title of this chapter that the following pages are filled with the condemnation of all cloistered groups as idle, lazy, immoral persona, unworthy of the name religious. Such, however, is not the case. All were not deserving of the fate which befell them in the 1530 's, but some were. In this chapter attempts hall be made to point out the instances Where monastic life was slipping; but it must be remembered that there were many exceptions to all the cases of laxness. All monks and nuns could not be charged with neglect of their vows, all could not be accused of immorality, but because a portion refused to live up to certain standards, all were made to suffer. Some historians try to excuse those exring monks by saying that they were not super-beings, but mere humans and thus were liable to submit to earthly temptetions. That is true enough, but it must also be remembered that the secluded, religlous ones had pledged themselve to be little better than their fellowmen, to live on a higher plain than that inhabited by the rest of worldy mankind. Since they pledged themelves to higher idesls and to nobler Iife, more was expected of them. However many religious might have been immoral, 
It is impossible to calculate the number that did not fall into this category. Writera of history and Iiterature always seem more than anxious to call to their readers' attention the many instances of disobedience, neglect and scandal; whereas the courageous, useful lives of others pass unherelded by the chroniclers. Condomation is so choap; praise is so dear. The sensational scandals in the cloistered places wer pablicized far and wide, but how many ecclesiastical recor de list the number of obedient, truly penent religious souls who were living during the same age? Thue the difficulty confronting the historian is the impossibility of forming any reliable estimate of the percent of religious who really justified the layman's bellef in them.

The foundations of all monestic life were laid deep in what we might oall the four pillars of monaticism, that is labor, chastity, seclusion, and the possession of no property. When some monks began to disregard these vital obligations, they were dooming their order to destruction, whether in 1537 or in 1625 only circumstances could tell. One of the first vows that a man or women took upon entering a religious life was that of relinquishing all property and possessions and promising not to acquire more. 
St. Francis commissioned his followers thus: "'I command positirely', he said, 'all my brothren that they receive no money in any way, directly or indirectly; that they acquire no property, no house, no place, nothing whatever.'nI Ere many decsdes had slipped past, the friars, following the precedents established for them by the monks, laid up for themselves and their houses earthly treasures. Originally the friars were nomads who trevelled about rendering services wherever they might do good. They had no cloieters, nor posseseed any worldly goods. Whereas the monks, on the other hand, had always IIred settlod lives within the monasteries. However, by the fifteenth century Iittle distinction could be made botween the two groups. There is little doubt that the clolsters of Fingland were wealthy establishments. What better proof do we have of this than the fact that thoir woalth and possessions were so extensive that they attracted the attention of the king and made even him desirous of making them his own?

One visitor in 1538 thus described the wealth and splendour of the Abbey of Glastonbury:

'A house meet for the king'g majesty and no man elso -- great, goodly, and so princely 88 wo have

$$
\text { 1. Beckett, op. olt., p. } 28 \text {. }
$$


not aeen the 11ke. There are four park adjoining, the furthermost of them but four miles from the house, well stocked with great pikes, perch, and roach; four manor houses belonging to the abbot, the furthermost only three miles distant. These princely mansions were dismantled, and remain still a wonder in their ruin.' 1

Another traveller hes left us his description of some of the monesteries.

The riches of Ingland are greater than those of any other country in Burope - above all their riches are displayed in the church treasures, Ior there is not a parish church in the kingdom so mean as not to possess cruciflxes, candiesticks, censers, patens, and caps of silver. Nor is there a convent of mendicant friara oo poor as not to have all these same articles in silver, besides many other ornements worthy of a cathedrsl church in the samo metal. Accoraingly you may imagine What the decorstions of those enormousiy rich Benedictine, Carthusian, and Cistercian monasteries must be.'2

Although the religious had been instructed not to acquire any personal property, somehow quite few of them conveniently forgot their vors. For instance, there were number of weal thy religious peors in the House of Iords. "Sixteen had a revenue of which the highest was equal in our money to $x 48,000$ year, and the lowest to II2,000. Six had equal to over II2,000 a year; and eleven had from $L 5,000$ to 112,000 ."3 These annual incomes were rather a far-cry from the early admonition
1. Geikie, op. c1t., p. 341.
2. Ger, op. cit., p. 17 .
3. Goikio, op. cit., p. 261. 
"no personal property." "The monks were living country gentlemen, not always of high repate."

Around the year 1200 four attempts were made by the popes to stop the monks from aquiring personal property. They decreed: ". . the monk found in posseasion of private property at his death should be buried in the dunghill, in token of his damation." Th1s threat, however, seemed to have little effect on the brethren. Although they were admonishod to put Whatever came into their possession into the common store of the cloister, oftentimes the temptation of self-aggrandisement proved too great for even the religious. In 1303 the monks of Festminster are said to have robbed the royal treasury.

The famous robbery of the rojal treasury showed that even in the cloister money could be used as well as hoarded. Suspicion fell on one of them becouse he dressed so finely and boasted of his wealth. After the imprisonment of many of them in the Tower, the sacrist and sub-prior were found guilty, and after their death the robberg' skins were fastened to the doors of the treasury beside the chapter-house, to be a warning to the evildoers of the future.3

Stories, amoing and childish, were spread among the cloisters of the fifteenth and sixteenth centuries

1. G. W. ChIId, Charch and state Under the Tudors, p. 41.

2. G. C. Coulton, The Modieval Scene, p. 79. 3. Capes, op. oit., p. 298. 
in an effort to impress upon the inmates the necessity of remombering their obligations.

One is said to have appeared after death to a brother monk and complained of the pains from which he suffered becanse he hed hid his old shoes when new ones were distributed among the household, intending to give them to his father. The shoes were found and put back in the common store, and the spirit came back to thank his friend for the care which had released him from his pains. It canterbury a rule was made that the 'vice of appropriation' should be punishod even after death, the bodies of offenders disenterrod, and cast out of the monastery.1

Bren the threat of dire punishment and the tales of departed souls doomed to wander the oarth failed to curb the selfish appetite of some of the religions. By 1600 so many had acquired the taste for "possessing things" that cob-webby veils of disuse seemed to shroud completely the old law of st. Francie, "no property." Before considering the noxt piller of monesticiem let as consider for a moment the fact that, besides not feeling themeelves in the wrong by accumulating personal property, the prolessed religious also frequently went against their better judgment and did and said things that were contrary to the dictates of their conscience, in order to adrance themselves. For example, such a case as that of Thomas More and the Abbot of Westmingter might be cited. 
In 1534, Sir Thomas More, under arrest for refusing to acknowledge King Henxy' supremacy orer the Church, was put in (Abbot) Boston's custody for a fer dajs. He tells us in a letter to his deaghter how speciougly the abbot tried to persuade him that conscience wa not a guide to be followed when it was inconvenient.' 'Then saide Iorde of Westminster to me, yt haw soever ye matter seemed to mine owne minde was erroniouse, when I se the gret counseil of the reslme determine of mind the contrary, and that therefore I ought to ehange conscience.'1

The socond pillar on which monasticism was baged was labor. In the early days when a monatic estate consisted of a crude abode surrounded by a fer acres of ground the monks found ample duties to keep them occupied. They tended their own land and performed all household tasks as well. But as the size of their estates grow and more and more land came into their possegsion, the place of the monk shifted from agricultural laborer to landlord. In fact, by the jear 1300 this change had taken place. "It had become very exceptional for monks to work with their own hands in the fields or at any handicraft. The services they rendered to agrioulture pere rather as landlords than as labourers."2 This ohange is not spoken of in a critical spirit, for with such large estates no other arrangement would have been possible. The monks could

\footnotetext{
1. A. I. N. Russell, Mestminster Abbey The Story of the Church and Monastery, p. 15 .

2. Coulton, Medieval scene, p. 80 .
} 
no lenger personally cultivate the bige tracts of 1and. The change to landlordship was the only alternative lett to them. As country landlords the religions were certainly no worse than others of their day and posibly were a great deal better.

Not long after the monks gave up their duties as progressive tarmers, the members of some of the houses, especially the larger ones, also began to neglect their household activities. Servante began to be taken into the houses and tasks were gradueliy shifted Irom the monks' shoulders to theirs. Accounts have been found where at the time oI the dissolution, there were more servants employed by monastery than there were inmates, thus showing that duties formerly carried on by the eloigterers were now performed by hired servants.

The acoount rolls tell us that the monks did not even share themselves, wash their own Ilnen, do their own kitchen or household work, or mow their own cloister-garth; these things were done by hired servant male or female. In a large monastery, there rere usually servants in the proportion of three to every two monks." 1

The monastery employed not only a large number of servants, but these servants usualiy managed to enrich themselves while in the hire of the religious. At the monestery of Bury st. Bdmands, the offices of first cook and gatekeeper were so richly compensated that they were 
held by hereditary succeseion. Similar conditions existed elsewhere. At Glastonbury a girl was appointed as butler; 66 men were hired to do domestic work, in sddition to the meny farm laborers. One porter at st. Mary's, York, in 1404 fared so woll that in his will he left 44 cows, 400 sheop and some land that he had acquired. At an early date the monasteries began to hire lay brothren (conversi) to help, elther with the household duties or with the farm work. However, by the fifteonth century the religious were described by many popular writers of the day as being country gentlomon who enjoyed themselves as thoroughly as their secrlar neighbors. 1

The third pillar on which monastic life rested was that of strict moralitj. Here is the question which probably cansed more controversy in the 1530's than any other 1ssue brought forth in this religious war. If Henry VIII did any mod-slinging, this was the place where his agents worked orertime. The fary of war-time propa-. ganda and that of political campaigns is mild compared to the charges made against certain of the religions. In the following pages some of the accusations will be montioned. It 18 impossible to estimate what portion 
of them is true and what created for the purpose of degrading the religious in the eyes of all England. It must be remembered that many of these malicious tales were propaganda. However, it seoms rather incredible that all could be so. Where there is smoke there may be some Iire. The cloisters were not all dens of vice and immorality as Henry Tudor would have us believe, yet all were not above reproach. There was some immorality among the religious long before Henry's agents atarted to work, yet not as much as the Commissioners reported that they found.

of the nunneries we hear much less gossip than of the homes of the monks. This, of course, might be partly due to the fact that there were very few convents in Fngland compared to the large number of monasteries. However, even of these few nunneries little scandal was circulated. For the most part, the ladies of the religious bodies were much better behaved than their religious brethren. In the Comperta, Layton and Leigh mention very few cases against the nuns, whereas a multitude of accusations are charged to the monks. of the thirteen counties that Cromwell's agents visited, only 27 nuns are charged with any wrong-doing.l 
In the aubsequent reports of the mixed commiseions the character giren to the convente is uniformly most excellent. Thus the White runs of Grace Diea in Ieicesterehire, the only convent of the order in England, are declared to be 'of good and virtuous conversetion and living, and all desirous to continue their religion the re and none willing to have capacities to return to a life in the world. I

There were, of course, some unfarorable piotures drawn of the sisters, such as in the satirical poem, "Why I Can't Bo Nun."

A lady called experienoe took her to a house of 'women regular', which was fair without, but not woll governed, for dams Pride and Hipocricy were there, and dame Invy too, in every corner. But Patience and Charity were not within: an outer chamber had been made for them. 2

Caser such as the one mentioned above were exceptional. The literature of the time did not poke fun at or condem the inhabitants of the convents as it did those of the monasteries.

The lighter literature of the time deals tenderly with the nuns, and drope its tones of cosrseness and satire in their presenoe. -- On the whole the bishops' Registers, when they raise the vell rarely disolose gross misconduct, nor does it seem that things grew much worse as time rent on. Immoralities confessediy there were at times; but when they became known the bishops' hands fell hearily on the poor fratl women. 3

Fither Henry's agents orerlooked the convents in the ir campaign of propaganda, or most of the houses were 80
1. IbId., p. 205 .
2. capes, op. cit., p. 305.
3. Ib1d., p. 305 . 
far above reproach and were held so high in the opinion of their contemporaries that they felt it would do littio good to try and blacken their reputation. Even Chaucer favorably describes hie prioress:

of grete disporte

And full plesant and amiable of port, but refined and dignified and worthy of respect, And all was consclence and tender herte.1

on the other hand, muoh can be said of the lax morals and loose living of the monks.

'Every act of legialation in the Church tends to show the 10 w condition of morals among the clergy, and their neglect of duty'. They are charged, besides, with constant quarreling and litigation with one another, with frequenting taverns, shows, cells of suspected women, and unlawful games. 'It is admitted by $a l l$ persons and by all parties that the charch from this time (fifteonth contury) and a century before till the age of the Reformation was in point of morals and leglelation in a very degraded state.' 2

It has eren been said of some of the religious houses: "The monsteries had become stables for clerks, or fortresses for fighting men, or markets for traders, or brothels for strumpets, in which the greatest of crimes wes to live without sin." 3

Fish's famous pamphlot helped to accomplish somo of the things that the king desired to have done. In his work, Fish accuses the monks of many practices of
1. Capes, op. cit., p. 305 .
2. Child, op. c1t., p. 42 .
3. Flick, op. cit., Vol. II, p. 447. 
immorality.

The monks, he tells the king, 'be they that have made a hundred thousand idle dissolute women in your realm, who would heve gotten their living honestly in the sweat of their faces had not their superfluous riches allured them to lust and idloness. These be that when they have drawn men's wires to such inconsistency, spend away their husband's goods, bringing both man, wife, and chilaren to idleness, theft and beggery. Yea, who is able to number the great brosd bottomless ocean sea fall of evils that this mischlevong generation may bring upon us if unpunished?'I

During the reign of Henry VII the people of Carnarvonshire complained to the crown. "Among the records of Henry VII is a memorial from the farmers and gentlemen of Carnarvonshire complaining that their wives and deughters were systematicaliy seduced by the clergy." 2 Probably the most corrupt and degraded house was the old and very wealthy cloister of st. Albans. Even Catholic historians can find little good to say in its behalf. Long before Cromwell and his men came upon the scene, this house was notorious for its lack of discipline and religion and for ite open, worldly living.

The old and rich abbey of st. Albens was a den of prostitutes, with whom the monks lived openly and avowedly. In two if its priories, the nuns had boen turned out, and their places filled with courtezans for the shameless use of the monks of St. Albans. 3

1. Froude, op. cit., p. 103.
2. Flick, op. cit., Vol. II, p. 447
3. Ibid., p. 447.


Countlese charges were made against the monks. Drunkeness was said to have been very common among them. One monk, Ulrich von Hatten said: "'It is gay time to Iive in our day.'"l Many stories were repeated of the immoral life led by numerous of the religions. one of the favorite ones told by the common people of Shrewsbury was the story of the existence of a subterranean comanication between Fenlock monastery and Buildwas lbbeg. In defense of the religious it is asid:

There is scarce an old monestery in Bngland, but has some such story told if it, ospocially if it was a convent of men, and had a Hunnery in its noighborhood. These reports were probabiy invented and propagated in order to exaggerate the dis 80lute lives of the lonks and Nuns, and thereby to reconcile the multitude to the suppression of religions houses.2

Several years after the dissolution, Bishop Hilsey told of scandal which had been revealed to him in confessional twenty years previous, by a miller's wifo who had been very friendly wh the then Abot of Halles in Glovesetershire.

This abbot, he said, had given her many jewels that had boen offered to the celebrated holy blood of Hailes' and derided her awe for the venerable relic itself, telling her it was but a duck's blood contalned in phial.3

\footnotetext{
1. Ib1d., p. 453 .

2. Phillips, op. eit., Vol. I, Appendix II.

3. J. Gairdner, English Charoh in the Sixteonth Century, p. 200.
} 
There was talk of the concubines kept by the holy men.

'Priest-girl' was a common term during the late Middle Ages and entire cloisters kept these women within their walls. -- Many monks kept their mistresses openly and even bought them houses in which they supported them. The priests had their concubines, and threatened punishments for such irregularities had ittle effect.

Some superiors tried to clean up their charges. Uaing the modern mothod of high taxation, a certain bishop thought that maybe he could end this evil if he taxed each of the 11,000 concubines of the prieste in his diocese. One abbot is said to have admitted that he could not enjoy life without his doge and women. Another was referred to as a second solomon since he unselfishly loaned his wives; others died of syphilis and of drunkenes8. 1

the Catholic historians olaim that all these accusation were malicions lies told about the religious. The Catholic author, Constant admits:

So violent are those imputations thet, if they were true, the English monasteries deserved a name other than that of religious houses. No doubt there were seandels here and there, but there are grave reasons for believing that the visitors purposely exaggerated.2

Edmond Burke waves away the charges by saying: "I rather suspect that vices are feigned or exaggerated when profit

\footnotetext{
I. A. C. FIICK, DecIine of the Hediovel Church, vol. II, pp. 296, 297, 300.

2. Constant, op. c1t., p. 161.
} 
18 looked for in their punishment. An enemy is a bad witness; a robber is a worse."nl

If, as some asert, the chargeg brought back by the commiseioner and the tales told about the religious in the seventeenth century were exaggerated or intentionalig created to ruin the reputation of the monasteries, there is still another plece to look for further ovidenee. In the fourteenth and fifteenth centuries reports were kept and storles were told, some of which have come down to us at the present time. wach of this material was in existence years before the days of the Tudors and certainiy no one will go so far as to claim that somo kind, far-sighted soul of the firteenth or sixteenth centuries foresam Henry VIII's actions and thos, very thoughtfully atarted preparing for him propaganda which he could pick up and use two hundred jears later. The report of a visitation in the diocese of Norwich made in the early part of the fifteenth century reveals that some of the houses were in a very bad condition. "The editor of the report says of the priory at Wymondham that in the whole course of its history wo hear littlo or nothing to its credit." 2 In Walsingham priory it was found:

$$
\begin{aligned}
& \text { 1. Constant, op. cit, pp. I6I, Ite. } \\
& \text { 2. Capes, op. c1t., p. 300. }
\end{aligned}
$$


The prior was living a dissolute and scandalous iffe; he robbed the treasury of money and jowels; he kept a fool to amuse himself and his friends with his buffoonery; he was commonly believed to be keoping up an illicit connection with the wife of one of the servants; ho behaved towards his canons with the utmost violence and bratality; and the result was that the canons themelres were a dissipated, noisy, quarrelsome set, among whom the very pretence of reilgion wes hardly kept up. .. of course, the servante vere insolent, the boys in the school mutinous, there were eril reports everywhere and not without foundation; for the canons frequented the taverns in the town and wor se places, and hawked and hunted, and occesionally fought and sceled the walls, and got out of bounds at forbidden hours; some broke into the prior's cellar and stole his wine, and some to up all night drinking, and rolled into the chapel in the early morning and fell asloep and mored.' 1

One of the earliest charges was that made by the

venerable Bede.

There are some men, who under pretenoe of bailding monasterios procure lands from thel $r$ kings which become their inheritance; and having obtained exemption Irom all secular gervice on that account, here they more quietly onjoy their lasts: .. but those that design to spend their youth in chastity, are obliged to go abroad for their education, to the prejudice of their country which wants their service. Besides those who are edncated in them being under no vows of chastity, run into such excesses, that they debauch the very women who have rowed chastity to God.' There is no ground to believe that the corruption of these societies was ever reformod or cured, till they were involved in the common calamities of the nation.

The register of John Stafford, the Bishop of Bath and Wells, cites several cases of lack of discipline and order within that diocese.

1. Capes, 0p. cit., pp. 300-301.

2. Warner, op. cit., Vol. I, p. 143. 
Burton -- The prior, John Schoyle, had allowed the diselpline of the priory and its estates to fall into disorder, and it was clear that he was quite unfitted to rule over the house. Bishop stafford was at the priory 15 April and again 19 September, 1427 , and on March 20, 1428, issue a series of injunctions concerning the principle and menagement of the prior wich he called upon the prior and canons to obey. Irreverence in the Conventual Church seemed to prevail and the canons were wont to walk about and hold conversation with suspected poople during the celebration of the Mas8. It was caid thet the prior himself scarcely celebrated mass twice in the year, and he is expressiy enjolned to colebrate at the greater Double Feasts and to be present on Sundeys and festivals. . . All women are to be forbidden access to the priory and one woman who was evidently suspeoted is expressiy ordered to be refused admitance into any part of the priory buildinga. - Again 21 Norember, 1430, the bishop wrote strongly to the effect that he had hoard that the prior and convent had not attended to his monition and that he would suspend all who presided over the house if obedience was not promptis shown. He further ordered the anb-prior to read the injunctions thet he had put forth twice weekly in the chapter house. The removal of suspicious women was expresely ordered. 1

Glastonbury -- The finances of the house as well as the morals of the monks seem to have noeded the abot's attention, and we find in 1443 that he had to prosecute Bartholomer Downton of Iyllington in Dorset bocause of his unwillingness to give up his accounts when he was receiver in that county for abbot Chynnock.2

Nuchelney -- The report of the abbot of Glastonbury does not seem to have been favorablo, and on 1 August, 1437, the bishop aummoned the abbot and all the monirs to appear before him in their chapter house on 30 August. In the following october the bishop through his comissaries convey to the abbot the bishop'a order that a certain gate at the east of the conventual church called Sexteynegate is to

$$
\begin{aligned}
& \text { 1. Holmes, op. cit., Vol. I, p.x. } \\
& \text { 2. Ibid., p. xli. }
\end{aligned}
$$


bo permanently closed. He had heard that lanndry women and others were in the habit of using it all hours, and geve canse for suspicion, and this danger mugt be prevented. He also forbade the monks for going out for pleasure and shows. It was evident that the discipline of the house was somewhet lax.I

Hempiton -- It has been discovered in the visitation thet dishonourable women have access to the priory and very often come there, with whom the prlor and brethren heve dishonourable converse, whenoe arise various temptations contrary to the dictum of Jerome to fleo society of women, and on that account the bishop enjoins on the prior and convent to abstain al together from converse wh suspected women within or without the priory and not to permit such women to come to the priory in places and t hours likely to arouse sugpicion, and specially enjoins on the prior entirely to ropel from his society and company Joan Carvyle, wife of Thomas carvyle and admit her not to his presence either in the priory or in any place without.?

1435 -- Comision to the abbot and convent of Mucholney, reciting that, although the bishop intended to make a personal of their conventual church for the reformation of excesses which (he grieves to say), according to comon report, heve for some time grom ap therein, not without scandel, he is still too much engaged in a rariety of important occupations in the office of chancellorship, in which ho labours to come to the said place for this; and that he has called upon Sir Nicholas. Frome, abbot of Glastonbary, to make a visitation of their monastery in his name. Deted in Wokey Manor, 27 Margh, 1435, the eleventh year of his consecration. 3

Mandete to the abbot of Muchelney to appear, with all those of his house who are bound to attend the bishop's visitations, before him on 30 August in the

$$
\begin{aligned}
& \text { 1. Ibid., pp. II, XI1. } \\
& \text { 2. Ibia., p. } 83 . \\
& \text { 3. Ibid., Vol. II, p. } 182 .
\end{aligned}
$$


chapter house for a visitation, which he intends to hold there, on that or following days, because of frequent reports brought him of neglect of the divine office in thet house and of dissolute morals of the monks. Dated in Dogmersfield manor, 1 Augast, 1437.1

Commission to the abbot of Muchelney of the order of St. Bonedict, -- reciting that in the bishop's late visitation of the abbey it was found that there is a gate at the east gate of the conventual church commonly called 'Sexteynegate', by which suspected persons and especially women of loose cheracter, by colour of laundry and other pretended services have entry at undue hours and times, giving cause for suspicion and some of the monks also pass out for pleasure and show; nay more some after complain go out singly by the said gate and are seen alone within the walls of the monastery with persons of doubtful character, and by this gate also victuals which should be distributed in alms to the poor, are taken out for the ase of such persons; and that the bishop hos decreed that the gate hall be closed and romain so; and commanding them within flfteon days to have the same walled up at the charges of the monastery, until the occraion of the scandal bo known to be at an end and they have other order from him. Dated in Dogmersfield manor, 3 october, 1437.2

In the year 1455, Archbishop Bourchier formed commission to reform the religious in his diocese. In speaking of the oloisterers, he said:

Some - - like vagabonds and profligetes run about through the kingdom and apply themselves to worldy gain, to revellings moreover, to drinking bouts, and to wicked adulteries and fornications, and besides, apend their time on all manner of vices, and waste the property, goods, fruits, and revenue of their benefices of this sort, and vainly and uselessly consume them on forbidden and profane objects. 3

1. Ibid., p. 209.

2. Ibid., p. 210.

3. Geo and Hardy, op. cit., p. 142 . 
In 1485 the Abbot of Spanheim spoke of the religious as:

- Ignorant, rade, and murdering the sheep of Christ by their infamons morals. 'No holiness of iffe,' he writes, 'no education, no purity is now required of candidates for ordination. . . . Instead of books they beget children, instead of study they seok concubines. The bishops are little better. They have either no copies of soripture, or fer, for they hate knowledge. They are set only on heaping up wealth. - . I foar greatly that worge times will come for the olergy ere long.' 1

Thus are a few examples of what was written of the monks many jears before the dissolution. All of this was said long before the slightest idea of dissolution of the monesteries was born. These charges were not propaganda, for in most cases they were writton by Churchmen themgelves, who realized the sad state of affairs in many of their houses and who foresar the result if conditions were not remedied. Over that period of years when conditions were deplorable within the eloisters, no great reformation took place and littlo effort was put forth to better matters in any one place. Therefore, since no atep was taken to help stem the laxity, conditions were probably no better in 1537 then they were in 1337 or 1485. This could not be said of 2.1 houses, but probably many of the monastic population

$$
\text { 1. GeIk10, op. cit., pp. To-11. }
$$


in England were in need of some moral reformation. 1 Their quiet, religious life suffered greatly becanse of their newly acquired taste for "pleasures of the flesh and of the deril."

The fourth and last pillar on which monastic life was founded was that of seclusion, a complete withdrawal from worldiy lite and pleasures. It is a known fact that by the sixteenth century the majority of monks had dieregarded the order of seclusion and felt free to go and come as they pleased. This was in sharp contrast to the wishes of the monastic fathers, for St. Jerome himself once remarked: "A monk out of his cloistex dies epiritually, like a fish out of water.'n2

One of the reasons why so many religious, espocially the superiors of cloisters, were taken away from their daties was their participation in political life. As mentioned before, many of the religlona were called by the king to carry on business of state. "The

1. Inis nood is orident by the Iact that many of the church leaders themselves, even before the time of the Tudors, realized soms monastic reform vas necessary. All the reports could not have been falso exaggeration. Where there was so much talk of scandal, there mast have been some basis for these complaints. All could not be fictitious. Unfortunetely, the exact number or percentage of disobedience and irregularitiea can never be proved.

2. C. G. Coulton, Medieval panorama, p. 272. 
Church, no doubt, was a good training-8chool for statesmen."l wany of them had much influence in affairs of state. "In 1216, for example, from the North Province of England eleven abots and eight priors, and from the South seventy-one abbots and priors -- in all ninety religious -- were summoned to Parliament by Henry III."2 "Iwenty-seven of the mitred abbots and priors ranked as barons of England and sat, or might ait, in the House of Iords, with the bishops; and the realth of some of them was enormons. ${ }^{3}$ It has been estimated that there were more spiritual peers in parliament than secular. 4

Besides being involved in carrying on business of state, some religious moddled in political aftairs for various interests of their own. For instance, a letter written by the Prior of Durham, shortly after the battle of Towton-Fiela, show that the master of Jarrow was in restraint since he had proved himself favorable to tho house of Lancaster.

'Right noble and worthy lord, I recommend me in my most humble wise unto your Lordship. -- I would beseech your Iordship that -- he (Master of Jarrow) might come unto you for his declaration; others

1. Galrdner, op. cit., p. I.
2. Gasquet, English Monastic Iife, p. 195.
3. Geikie, op. cit., p. 261.
4. Iiljegren, op. c1t., p. 15.


tell that it might like your good grace so to provide for him that he may ourely ride and 80 in the country, where he 1iketh, for the well and profit of his place; for I dare say and make it good that he is, and hitherto has been, a true man, willing unto King Edward, Lord of Warwick, unto jon, and to all that belonged to that party. Written at Duresme, the fifth day of July, 1461. By your true and continual bedemen, John, the Prior of puresme, 1

Many of the religious of the realm vere engeged in politics and thas conld not derote the timo they should to their religious duties. Those who were not important enough to interfere in state affairs, followed their superior's practices and likewise forgot thelr vowa of seciveion. They went outside the monastery on many occasions, staying away days at a timo. The nuns Fere also guilty of this.

We may gather from the episcopel letters and injunctions that the nans enjoyed mach freedom of intercourse with the outside world, could pay visits in the neighbourhood to their friends, and even stay a night or two abroad. The bishops commonly assure that this was usuel, do not treat it as irregular, but only try to fenes it arouna with aafeguards which may check possible disorders. The nuns of Godstow, for example, mast really be more careful and not chatter or joke with oxford students; the nuns of cannington who have leave to stay with their friends in Exeter mast not go elsewhere without permission; the sisters of uynchin Baroov must wear their proper dress when they 80 abrosd and not ataj out too long, and wander in levity from house to house.2

Houses of Jarrov, p. mi.
2. Capes, op. cit., pp. $302,303$.


"Chancer's Shipman's Tale, where the monk of St. vennis comes out whenever he Iikes to vielt his friends in paris, is a perfectly notural picture of ordinary practice."l Wolsey, during his early career saw how often the religious were leaving the seclusion of the monastic walls for the world outside. "He 88w the realities of the Church sacrified to the unrealities of the pessing hour. He sew Churchmen neglecting thet which wos God's for what they could get from caesar." 2 Next let us turn to the four monsetic duties and activities mentioned in chapter IV, prayers, hospitality, charity, and education, and see whether on the ore of the dissolution they were being performed nobly, or whether they were being neglected. The first duty mentioned is that of monastic prayers for founders, patrons, decersed superiors, and for all christion souls. many of the religious probably continued devoutly in their prayers up until the time of the dissolution, but there rere some exceptions to this rule, and the exceptlons were not few. In one monastery it was discovered after a visitation was made in the fifteenth century that the religious atmosphere was not always conducive to silence and prayers.

1. Coulton, hedieveI soene, p. 81.

2. Taunton, op.c1t., pp. 7-8. 
They were certainly no happy family; irreverent and remise in the discharge of their duties in the cholr or at the altar, they disturbed each other by their loud tones while at service, walking about the church when they should be in their places, gabbling through their private prajers while the high mass was going on, or making their confessions while wandering about the nave.1

By the time of the dissolution the religious had worked out a sgtem of rotation by which only a certain number of the members of a whole house would have to be present at each service. Thus each cloisterer had only a certain number of services to attend and all were not required to be present at each service. Nlthough they have been criticized for this rotation, actually the rel1glous would here been able to do little else. Had each member been required to attend every service, there would have been very little time left for other necessary functions.

However, one of the monastic enemies contends that this system of rotation was further proof that the religious were not attending to their duties nor living up to their rows. By only having to attend a certain number of services, the monks were given more opportunity to attend to their personal pleasures, thus taking more of their time away from their divine duties. This system of rotation by which only a proportion of the religious

$$
\text { 1. Capes, op. cit., p. 252. }
$$


wero present at divine service seems difficult to reconoile with their obligations to founders and benefactors." 1

Another duty of the monks closely connected with praying was the burial of the dead. By the seventeenth century some of the religious had become so mercenary that they refused this sacrament to those who required 1t. During the early part of the sixteenth century an anusual petition was presented to parliament about the unheard of demands that some of the religlous were making. "It complained that the clergy refused burial until after the gift of the decosed's best jerrel, best garment or the like, and demended that every curate should administer the sacrament when required to do so." 2 The second activity of the monks was thet of hospitality, one which was greatly appreciated by medieval wayfarers. However, it has been charged against the religlous that they cansed to be constructed hospices or inns near the monastery, so that they would not have to open their doors to visitors.

At St. Albans towards the end of the fifteonth century, it seems that hospitality was quite dying out. The aboy, which of old had stabling for 300 horses, granted a licence to the landlord of 'the
1. Baskerville, op. clt., p. 21.
2. Pollard, op. cit., p. 235 . 
George' to have an oratory and low mass for the greet mon, nobles and others, who should be lodged at his hostelry, for they came no more to atay vithin the abbey walls. So too at Abingdon, while travellers of rank were entertained at the abbot's table there had been a hosplce attached to the abbey for the meaner guests, but in 1414 this was superseded by a 'now hostelry' leased out by the convent at a yearly rent as a public inn. We hear of Iike conversion of the hospice into a public inn at GIsstonbury and at Burcester, in the latter case soon after 1379, and the Pilgrim's Inn at Gloucester pointe perhaps to a like charge. I

The entertaining of visitors was come expense to the smeller houges and some claimed exemption from this activity by the fact that their incomes were too limited to take in visitors.

Al though some of the houses may have been turning thelr job of providing hospitality for travellers over to others, many more places continued to fulfill such obligations. In the county of Hampahire were two famous houses, well known for their hospitality to sea-faring travellers, the monastery of Quarr and of Hetleg. ${ }^{2}$ christ Church must have been a popular place since the prior claimed that it was the only haven of refuge from within e1ght to eighteen miles. 3 These houses, unlike st. Albans and Glastonbury, continued to fulfill their hospitable duties and because of such service endeared themelves to
1. Capes, Op. CIt., p. $88 \%$.
2. Baskerville, op. cit., p. 29.
3. Ibid., p. 29. 
many.

Arguments of this kind were reinforced by men who either had no aympathy with, or who had lost what they had in, the religions life; as is seen by Bishop Iatimer'a pleading for the priory of Great Malvern, by Bishop Barlow for Nostili, or by Sir William parr, a prominent innovator in religion, for Pipewell Lbbey. There can be no doubt but that the disappearanoe of the monastery was a cause of great inconyenience to many travellers, rich and poor.1

Coming from an author whose ancestore profited well by the dissolution, this is quite a compliment to the rellgions.

The thira actirity of the religious was that of almsgiving and charity. In the performance of this duty, as in that of all others, many of the houses were not fulfilling their obligations. on the other hand, a fer conscientious oouls still felt it their dutg to take care of their less fortunate brethren. For instance one superior was so concerned over the fate of those he had cared for while ho was in authority, that after the dissolution he wrote to Cromell in their behalf.

Robert Perrar to Crommell

15 Hovember, 1539

I hestily beseech your lordship to be good and favorable to my poor fellow servants and other poor people which had relief and sacoor oft me there, and verily I found Master Henley most worshipfull. -Master doctor has taken possession of your farm of Huntwyke, myndynge so to have doone atto the poor 
cell of stokyeke whereunto I had put (by the whole consent and deed of the convent) a very poor man which married my sister, having many small children and no house to dwell in, both good Master Henley considered the poor man needy and also your honorable letters concerning my mension have referred the matter to jour lordship.

Robert Perrar, late of S. OBwaldes

(Vol. 155, p. 13)1

The work of the nuns is often spoken of in

connection with the charity work of the religious. They were especially capable in the capacity of nurating and lending whet medical aid they could to neighbouring peoples.

It has been geid that there were houses where the nuns were nurses and midwites, and eren now the ruins of those houses contain certain living records of the ancient practice of their inmates in the rare medicinal herbe which are still found within the precincte.' 8

Unfortunately, howerer, the mojority of the religlous were not as faithful with their philanthropic work as they should have been. In most of the houses, especially the larger ones, funds had been set aside by the will of the founder or by endowment for that purpose to feed the poor and give alm to them. For instance, at I11leshull Abbey:

Iadj Katherine Ieveson left rent of II20 per annun issuing out of Poxley, for the malntalnence of trelvo

1. Clay, op. o1t., p. 13.
2. Capes, op. o1t., p. 304.


poor widows, whereof three were to be chosen by the Minister, Church Warden, and Overseers of the poor of Iilleshull; and to each of them gown of grey cloth, with these letters, K. I. in biue cloth offixed therto; as likewige for the placing of ten poor boy apprentices, whereof two were to bo of this parish.1

However, when household expenses became great and in times when the budget could not be balanced, part or all of this donation to the poor was oftentimes withheld and used by the house itself. Savine has estimsted: "rot more than $3 \%$ of monastic income was apent on charity."2 Another calculation claims: "Not one-tenth of the enormous monastic incomes were spent upon charitable purposes." 3

Several cases are recorded where the money which had been intended to be spent on charity was going for other parposes. For instance, at St. Peter's, Gloucester:

The archbiahop found it needful to insist in 1301 that all the proceed of the Manor of Stanedisch should bo spent as by rule upon the poor and that there should be no general onterteining with good cheer at their exponse. The Manor of Alton had been set aside $(1080-87)$ by the lbbot of Hyde with the assent of the brotherhood for the maintenance of the pilgrims and the poor, and the deed of gift expressed with the wish that any one who robbed the poor of this 'might have his portion with Dathan, Abiram, Judas, and Hero'. But in the injunction of IIIfam of Wykeham to the abbey it ataded that the poor and the infirm had been defrauded of their portion, notwithstanding the pious intention of the donors, and

1. PnIIIIps, Op. oIt., VO1. 1, EppendIx G-21.

2. Baskerville, op. cit., p. 31 .

3. Coulton, Medietal Scene, p. 81. 
Iike complaints were made elsewhere, when the broken meals and cast-off clothes were no longer. distributed, to say nothing of more costly gifts. ${ }^{1}$

This money which the monks took upon themselves to discharge as freely as they pleased was, after all, not their own, but merely left to them to guard as trustees. Hot only the money itself was ill-appropriated, but eren the food and clothes which were to be given to the poor were many times re-routed inte the possession of some of the abbots' friends or relatives, or what was even worse to the abbots' dogs. "The sub-prior lof Westacre) does not give the fragments to the poor but to his own friende, especially to Mrs. Heseney and another ladj.'n2 Alas, but what a far cry this was from what the original dispensation of food from the monks' table had been intended.

"It may be said in favour of the suppressed religious houses, that while they. stood, no act was ever passed for the relief of the poor, so amply did these houses succour those who were in want." 3 This may have been true, but regardless of this claim, it is questioneble whether the charity work of the monks was as beneficial

\footnotetext{
1. Capeg, op. cit., p. 285 .

2. Baskerville, op. cit., p. 32 .

3. Phillips, op. cit., Vol. I, Appendix B-l. The question might be raised as to whether or not there was a great deal of need for relief at that time.
} 
as it should have been. It seems that the mere handing out of alms by the religious was likely to increase the rank of beggars rather than diminish their number. This dole system really in no way helped the unfortunates to better themselves permanently. What ald they did receive w8s only momentary and passing. And by simply handing them out "doles" it was likely to create permanent paupers rather than self-respecting cltizens. Beckett says, in speaking of the charity of the monks: "In its indiscriminate character was the occasion of increasing mendicancy with its train of vices; it was a charity which fed the clamorous with no thought of their improvement as fellow-beings." I In the ragrancy Iaw of Edward VI the term "abbey-lubbers" is outstanding. "It may mean sturdy beggars, or else the useless dependents and servants of moneteries against whom the bishops were always inveighing." It has been said that the type of philanthropic work undertaken by the religious actually did as much to increase beggars as it did to relieve them. 3

The fourth and lest activity of the religious was that of education. Perhaps in this, more than in any of

1. Bockett, op. cit., p. b.

2. Baskervilie, op. cit., p. 32 .

3. Ibia., p. 32 . 
their other duties, many monks fell short of their standards. By the beginning of the sixteenth century there was a definite inertia among the monks when it came to learning. There wore some who still pursued their studies zealously, but the majority only had the minimam education required of them. The grand old daye of Matthew paris were only a memory of the past. In spoaking of such scholars as he, capes says:

It is a great change to pass from the variety and picturesque detail of Matthew paris of St. Albans to the narrowed theme and duller style of his accessors, and in most of them the stream of monastic history fllows feebly on during some part of the fourteonth century and then commonly cosses altogether. It was not merely a change in the direction of their studies: the monks did not devote their energies to other forms of literary work, or become theologians and preachers. The great schoolmen had no successors in the elolster; the revival of ancient calture found little sympathy from them, and Gascoigne insisted bitterly on the decline of scholarship among them.1

\section{Ilkew1se, Patterson says,}

In the later thirteenth and fourteenth centuries they had produced great intellectual leaders among the schoolmen, such as Albertus Magnus and St. Thomas Aquinas among the Dominicans, Duns Scotus and William of Ockham among the Franciscans; but in the fifteenth century their intellectual was as marked as their moral decline. 2

Eresmus had something to add about the alarming lack of learning eren in his day and age. "What sight

$$
\begin{aligned}
& \text { 1. capes, op. cit., p. } 283 . \\
& \text { 2. Patterson, op. cit., p. } 184 .
\end{aligned}
$$


It is', says Erasmas, 'to see a theologian of eighty who knows nothing but empty sophisms, and can do nothing but dispate. . . Inl and at another time he is said to have remarked: "'Our theologians eall it a sign of holiness to be unable to read. They bray out the posims in the Churches like so many fackasses. They do not understand a word of them."n2 It is also interesting to note that in 811 the synods called together by Charles Bothe, the Bishop of Hereford, the articles and constitutions were read to the clergy in the Engliah language, which seems to confirm their scant knowledge of Latin. 3 The claim cannot be made that there were no gixteonth century monks who were intellectually inclined. There probably were some cagea where cloisterers purgued their studies with zeal and interest. However, tho deplorable fact was: "There was no widespread enthusiasm for learning." 4

The ignorance of the religious in the emell religious houses,' wrote Doctor Gwent, Desn of the Arches, to Cromwell, 'is incredible. They can't construe thoir orm rules." "There are iffteen brethren here,' wrote the sbbot of the large Ciatercian house of Varden in Bedfordahire, "and

1. Geikie, op. cit., p. 8\%.
2. Hague, op. cit., p. 224.
3. Bannister, op. oit., p. iil.
4. Gee, op. oit., p. 35.


except three of them, none understand nor know their rule, nor the statutes of their religion.' The abbot of Hayles told Cromell that none of his monks was learned onough to expound the scriptures to others and that he would have to get down an oxford don to do so. At st. Benet's, Norfolk, in 1532, four of the monks were reported to be so ignorant that they could searcely read or sing. I

The aniversity training of the monks was noticeably neglected. Of all the religious in Angland, only a very small percentage attended colleges.

It may be doubted if there were as many as a hundred monks and regular canons at oxford University at any given time, and at cambridge the number was always smaller; while the great monsatery of Rewley and oseney in the suburbs of 0xford, and that of Barnwell just outside cembridge, seem to have contributed Iittle or nothing to learning. OBeney 'though best in discipline of the oxfordshire houses and with 26 canona in 1445 had no school or no learned canon.' 2

The education of many of the monks was neglected because their aperiors were little interested in the purauit of learning. Many abbots and priors, and for that matter oven bishops, cared little about the achievement of their charges. certain Richard Nix, Bishop of Norwich was particularly bitter and harsh towards any person who attempted to better himself intellectusily. He referred to them as:

'. savouring of the frying-pan.' He solzed such books as were brought from beyond seas, of which sort there were now many, which tended to lay open

1. Baskervilie, op. cit., pp. 9-10.
2. Ibid., p. 4l.


the corruption of the Church and especially the New Testament, which he could not endure should be read. 1

Even the very pro-Catholic writer, Conotant admits: "It cannot be denied that the English monasteries, like many elsewhere, stood in need of a certain reform. They were no longer the sohools of learning they had been with a reputation commanding reapeot.nL

"'Woe is me, simple friars enter hearen, while learned Iriars are disputing if there be a God. $\mathrm{in}^{3}$ Even though their intellectual life did decline greatly, we must credit the monks with keeping their libraries in order and preserving for future generations valuable collections which once lost to the world could never be replaced. Even though they used these libraries very little, the books were preserved, and but for them the modern world would be without many of these ancient works. "It is greatly due to the care of generations of monkish librarians that manuscripts were preserved even if they were not always widely used." 4 some of the chroniclers of old were very proud of their care and seemed to realize the valuables they were guardians over.

1. Stype, op. c1t., VoI. I, p. 42.
2. Constent, op. cit., pp. 153-154.
3. Creighton, op. cit., p. 100.
4. Gee, op. cit., p. 89.


Their books were etill guarded with proud pride, even if they did not read them so much as of old, and it seemed to the chronicler of St. Albans an abominable thing when a careless abbot offered to transfer some of their classics to a famous bookcollector. 1

It can be seid of the religious that while in their poseession these ancient and oftentimes rare books were carefully preserved and their value appreciated, even if not by all the inmetes of the house, at least by the chronicler. Unfortunately, however, the same cannot be said of those mercenary souls who came into possession of them after the dissolution. To them the only value these libraries had was the number of shillings they could get by selling the booka. It has often boen told that many old valuable manuscripts were torn apart, page bJ page, and the detached pages sold to merchants for wrapping paper. Another deplorable report admits that after the dissolution two "noble" libraries were bought by a merchant for 40 . and taken over sea, although they were very valuable manuscripts. 2 After conturies of monastic guardianship and care, the rast collections were seattered as worthless trash by the four winds.

If all the charges made against the religious were
1. Capes, op. cit., p. 289.
2. Phillips, op. c1t., Vol. I, Appendix B-1. 
listed together, the fact would probably be very noticeable that the majority of their duties were negleoted. Of all the rarious activities mentioned in this chapter it seems that only that of hospitality was still being carried on somewhat as of old, with those of labor and charity runing poor second and with the row of chastity languishing behind. Unfortanately we cannot go back to old records and prove that 1,750 monks were breaking the vow of "no property," while 469 were still adhering to their strict code of morals. There are no definite figures by which to go. However, it seems probable from the evidence available that on the eve of the dissolution there were more oloisterers who were neglecting their duties and were failing to live up to their ideals and vow than there were those who were doing so. When Henry's Commisaioners turned in their reports, they claimed that one-third of the houses in England were fairly well conducted.1 Therefore, considering their tendency to exaggerate evils, it might be estimated that at least one-half were fairly well conducted. Granting that at least fifty percent were above condemnation and sugpicion, is this a record of which the Church could be proud?

For each vow and activity mentioned in this

$$
\text { 1. Wishart, op. cit., p. 3T\% }
$$


chapter there were undoubtedy some true religious who were nobly carrying on their work. Sadly enough we hear too little of them. only their less religious friends are publicized. Those who so faithfully went silently about their tasks, never shirking their duties, were harshly made to suffer for the meny careless ones who, forgetting their vows and monestic ideals, selfishly put the pleasures of man before their devotion to God, thas bringing about the downfall of monasticism in England. 
CHAPIIER VI

RRASONS TOR THE DECIINE OF MONASTIC IITE 


\section{CHAPTER VI}

\section{RRASONS FOR THE DECLINE OH MONASTIC IIFE}

Even though it is almost impossible to estimate the number of monasteries which had fallen into decay. or the extent to which they had decayed, it is certain that many of the English monasteries had fallen short of the ideals by which they were supposed to have Iived. It seems from the evidence gathered that there were more monasteries in need of reform than there were cloisters which could withstand all suspicion. To explain the decay of the majority of Engligh houses by saying that the monks and nuns were only human and too much was expected of them, is merely evading the issue. As there are almays reasons behind every movement in history, there were certain definite causes for the decline of monestic life. By studying these reasons one can understand why many monasteries might be in the condition that they were before their aissolution.

The charch by the sixteenth century had proved Itgelf to be a strong force not only in religions iffe but also in the political affeirs of Purope. The inflaenoe of the Catholic Church was such that it did not hesitate to disagree with high nobles and court favoriter, for that matter not even with kings themselves. The 
kings of fingland had been no exception to this ruie. Insuits and grievanoes that they would not have ondured from others they were forced to accept from the church. English rulers who otherwise were free from any foreign domination often felt the influence and power of Rome. As a result, the Crown usually suffered a loss of prestige.

An outetanding example of Rome's power in England is shown in the controversy of King John and the monks. When the rector of the Church of Feversham in Kent died, the king presented his candidate for the vacancy to the Archbishop. The monks of St. Austin's, olaiming a share of the profit, acted more quiokly than the King.

They immediately on the incumbent's death, sent one of their body to take possession of the church and parsonage; who by force kept out the clerk presented by the king. The king being excoedingly provoked at this proceeding, ordered the sheriff of the county to dispossess the monks; which was accomplished but not without a reaistance that caused some blood to be shed in the church.I

All attempts of the king and nobles to breech over the unhappy situation failed and the monks continued to .. affront the king. . - They know what great things their brother monks of the cathedral had done for the fee of Rome by their obstinacy, and what returns had been made them for it. They saw that every insult offered to the secular authority, did something towards lessening it in the ejes of the people; -- For this reason, wi thout taking any 
notice of the courts of Ian, the monks of St. Anstin's appealed to the court of Rome. ImNOCBNT, wo may be sure, immediately espoused the cause; and by an epistle, directed the bishop of Bly, to excommunicate those who had dispossessed tho monks, to pat the places they inhabited under an interdict, and then to restore the abbot and convent to their possession. The king forbade the execution of this insolent bull. . . INWOCENT accordingly wrote $a$ letter to the king; in which he tells him, that every one ought to stand or fall to his own master, and that it was not prudent in his majesty to intermedde in the affairs of ecclesiastics, of which he had not the proper oognizance. Accordingly, atter the king and the archbishop had had a great deal of Iruitless wrangling with them about the patronage of this church, the king, seeing no other remedy, but oither give up his right, or to come to an open rupture with the court of Rome, yielded at last to the usurpation; and permitted the monks to reap the fruit of their own pride and obstinanoy. Had this been one of the first steps towards humbing the English monsrchy, we might wonder indeed at the assurance of it; but they had been so frequently taken for many years past, thet they have no other effect now, than to make us wonder at the folly and the madness of the inglish nation, in permitting an imposture... to grow upon them.1

The subordination of monarchy to church authority continued up until the sixteenth century. Bren the nowborn Tudor dynasty had this threatening power held over them. The efficient Henry VIII, who ruled as well as reigned, lelt papal domination as a threat to his power and prestige. The king not only resented this foreign influence, but also looked askance at the constant stream of money which flowed from all parts of England into Rome. The worst feature of this practice was that many 
times the money which had come to Rome from England was lent by the Pope to one of Fngland's enemies. Although attompts were made at various times by the civil powers to stem the flow of gold to Rome, they did not succeed.

But the notion .. - continued in practice to allow the Popes to have a free hand in otherwise disposing of moneys left by Englishmen for the benefits of Religion in their own country. It is worthy to remark thet England in those days acted towards the Pope in most generous and filial menner; and often to her own immediate detriment, allowed him to exercise in temporal matters, a power which spain, France and Germany sternly disallowed.1

It has been said that the monks were papists first and Englishmen afterwards.2

One of the Popes once remarked: "Truly Finglend is our storehouse of delights, a very exhaustible well; and where much abounda much can be extorted from many."3

It is the great scandal of the medieval papacy that its chief visible relation to Fnglish Church people consisted in extorting money. . . its most irritative form was the payment of annates or firstIruits, which were paid by bishops and archbishops on their promotion and sent to Rome by the papal agents. 4

The Fnglish people, especially the Crown, seemed to resent this constant flow to foreign treasuries and in 1376 a petition of the Good parliament claimed:

\footnotetext{
1. Tranton, op. c1t., p. 26.

2. Hagre, op. cit., p. 304.

3. Taunton, op. cit., p. 37, footnote from Matthew paris.$$
\text { 4. Ger, op. cit., p. } 9 .
$$ 
'. - that the taxes paid to the charch of Rome amounted to five times as much as those levied for the King; that the Pope disposed of the seme bishoprios by reservation four or five times, and receired each time the first fruits. . . . that the Pope's revenue from fingland alone is larger than that of any prince in christendom . . that his collector remits yearly to the Pope 20,000 marks, sometimes more.' 1

The great influence that the Church had, coupled with the fact that possibly some of this wealth, had it not been flowing to foreign power, might have reached the king's coffers, made Henry VIII watch the Church with an anxious eye. When the chance came to cripple papal domination in Fngland by striking at its greatest stronghold, the monsteries, Henry did not allow the opportunity to slip past him.

When any organization decays and is so blinded that it fails to realize its need for reform that condition 18 bad enough. However, when a group, espeoially a religious one, is in need of reform and reorganization, and that noed is fully recognized by its members and yet nothing is done to right the wrongs, that situation is even more tragic. This was the case of the Catholic Churoh in the later Midde Ages. A reform from within the Church would have been much better for the Church herself and certainly not as detrimental as the reform from

I. Child, op. cit., p. 29. 
without proved to be. "A radical reformation of an institution which had survired a thousand years might easily hare brought the monasteries up to date, and here fitted them for a new epoch of beneficent work."I

It cannot be said that the Church was ignorant of the need for reform. As one of the canons of the church sald:

A clerical reformation, a reformation without meddling with the Catholic faith, had been attempted already by the best sort of clergy throughout Europe. Throe great councils had been held to bring it about - . and to each of these councils Ingland had sent representatives. The defeat of this attempted reformation by councils, which was effected by the intrigues of Rome . - is the most mournful event of modern history. . . It gave weight that no reformation was to be expected from the Church herself, and thas it opened the way for the invasion of the temporal power and for the doctrinal revolution which presentiy overswept Europe.2

At the beginning of the thirteenth century people realized that monasticism had fallen below its former standards and that some reform was needed. Even some of the newer orders had become too much influenced by worldiy things which they had vowed to renounce. Three ambitions and earnest Popes, Innocent III, Honorious III and Gregory IX tried their hand at reforming the monasteries, but little can be said of their success. 3 Even the Crown

1. Gee, op. cit., p. 8\%.

2. Taunton, op. cit., p. 62 .

3. Cheney, op. cit., p. 17 . 
reolized the need for reform and in 1371 sont a letter to the monks of St. Paul's in which their scandalous departure from the religious way of life was severely rebuked.l In the early part of the fifteenth century visitations were made in several parts of the country and detalled reports were left of the conditions found.2 In 1516 Bishop West of Ely visited the monastic house at Ely and found the need for reform most urgent. ${ }^{3}$ The Italian Bishop of Worcester wrote from Rome to a churchman in Ingland in the year 1518 that he was often impressed by the need of monastic reform. 4

When Cardinal Wolsey made preparations for a reformation, woll known prelate, Fox of Winchester, wrote to him as follows:

Great was the contentment and joy, most reverend Fother, which I received from your recent letter whioh tells that your Grace is set upon reforming the whole body of the clergy, and that you have notifled and fixed a day on which the work shall begin and be proceeded with. This day I have truly longed for, even se Simon in the Gospel desired to see the Messiah, the ixpected of men. . - As is duty bound. I indeed did strive to carry out within the limits of amall jurisdiction that same design which your Grace will soon bring about in the two provinces of this realm. For three years this great affair has been the object of m studies, labours, watchings, and travail, till

1. Copes, op. c1t., p. 252.

2. Ibid., p. 251.

3. Pollard, op. cit., p. 338.

4. Ibia., p. 338 . 
I found out what had hitherto esoaped mo -. viz. thet everything belonging to the primitive integrity of the clergy, and espocially to the monastic state, is perverted either by dispensations or corruptions, or else has become obselete from age or depraved owing to the iniquity of the times. As age was creeping on me, while the thought of this increased my will and desire, so all hope departed of seoing a revival, even in own diocese.1

Even though the Church and its officials realized the great need for reform, little was done about it and the many practices which were causing the constant decay of monastic life were allowed to continue. one of the privileges which the cloisterers enjoyed and one whioh tended to encourage lawlessness among them was that of immunities, or 88 it was often called, "benefit of clergy." The idea was based on the theory that the clergy was a sacred order and, therefore, should not be tried in the secular courts. Originally, upon suspicion of a crimo of ang sort, the clergyman was to appear before the king's court and claim "benefit of clergy." Whereupon he was turned over to his ecclesiastical superior, who had him tried according to church law in an ecclesiestical court. This privilege was claimed by the church until the aixteenth century, but years before that time many unworthy ones had taken advantage of this position. The immunities were being extended to such unimportant offices as door- 
Krepers and readers. 1

Not only many of the secular class were escaping punishment for their crimes through the right of immunities, but with the lowered standards and the laxity of morals and conduct among the monastic orders, many of the monks felt less hesitancy about committing offenses since they knew they would not be tried in a secular court. Quite a number of offenders thas esceped punishment, who otherwise might have been found guilty in the secular courts.

The laxity of the courts towards clerical offenders was notorious, and it often happened that the ends of justice were defeated by the sentence passed upon a delinquent. Benefit of clergy, the technical name given to the immunity of the clergy, had come to be one of the most crying scandals, for it had the effect of shielding criminals from punishment due to the offense, and as minor orders covered a large number of persons, the criminals who escaped penalty cannot fail to have been fairly numerous.2

Even the pro-catholic writer, James Gairdner admits:

This syotem probably worked woll and was attended with good results in the days when the discipline of the Church was superior to that of the state. But centuries had passed away since then, and the system had gotten roughly modified in different directions. 3

One of the rows that the monk took when he entered

1. GRirdner, op. o1t., p. 42.

2. Gee, op. cit.. p. 26.

3. Gairdner, op. cit., p. 42 . 
his order was the pledge to withdraw from the world, to remain secluded within the grey walls of the monastery and not to wander forth. In the case of the heads of monasteries and church ofticials, their obligation was to hold one office, to remain at their sppointed place and see that their duties were performed. By the sixteenth century many of these obligations assumed by the religious were conveniently forgotten or flagrantly disobeyed. In the case of the clolstered monk, the problem of diselpline always a greater one if the monks journeyed into the "outside world." They often made such a habit of leaving the cloister.

The Benedictine houses combined to keop a proctor at the curie to arrest any of their order who went thither without license. A prior of canterbury appealed even to the civil power to issue a writ of praemunire against a restless monk who hed managed to procure papal letters of exemption from monastio discipline without having first submitted it to the king's council. But the hands of anthority were sometimes weakened by the interested action of the papal agents. Thus the Carmelite friar, Walter Disse -- confessor of John of Gaunt -- was empowered to sell for Urban VI 50 appointments to the olfice of papal chaplain; these secured exemption from conventual control, and even liberty to take a rich rectory as well. A monk of St. Albans, William Bhapeye, begged or borrowed mongy to buy one of these and galned thereby his freedom.

In 1455 Archbishop Bourchier's Commiasion for reforming the Churoh reported:

1. capes, op. c1t., p. 297. 
The constant and noisy clamour of many, and public report, and the notoriety of the fact spreading it, it has now lately reached our ears, not without grievous bitterness of heart, that there are some within our diocese of canterbury, render the profession of monastic observance, who have got possession of parish churches and their perpetual vicarages, under the pretext of certain pretended apostolic letter, and having scorned and discarded their regular habit, or at all events contrary to the manner of their religion, abandon the same secretly under secular garb, some of whom also wear a habit inconsistent fashion, and go about rashly and presumptrously, like secular priests, in no wise fearing sentence of excomanication and irregularity passed in that behalf against such, and damnably incurring and contracting them to thus incur and contract thom.1

It was bad enough for the monks to forget their duties and "go-a-travelling," but the example was set for them by their superiors. The practice of nonresidence was often due to the fact that clergymen held more than one office at the same time. For example, Richard Fox was consecrated Bishop of Exeter in 1487, in 1491 he was transferred to Bath and Wells, and in 1494 to Durham. "Richard Fox is said never to have seen his cathedral at Exeter or to have set foot in his diocese of Bath and Wells."2 Cardinal Wolsey held at the same time: the Archbishopric of York, the Sees of Iincoln, Tournai, and Winchester, and the Abbey of St. Albans. "He was also a Cardinal, a Legate, a latere, and a

$$
\begin{aligned}
& \text { 1. and Herdy, op. cit., p. } 142 \text {. } \\
& \text { 2. Spence, op. cit., p. } 109 \text {. }
\end{aligned}
$$


Chancellor of Henry VIII." ${ }^{1}$

Bishops were often kept away from their diocese by their duties at court and thas no visitation or check-up on conditions in their territory could be made. ${ }^{2}$ As the poet, Thomas Hoccleve tells ua, the pluralist could care little for his charges. "His flock might pine in vain for holy sermonage. He rekketh never how rusty ben his schepe." 3

Al though the practices of non-residence and pluralities cannot be blamed wholly on the monks, nevertheless these must have had an indirect influence on the increasing laxity of their everyday 1110. Whout the fear of visitation from the bishops, they neturally felt Preer to do thinge which otherwise they might have refrained from doing. Among the things which were being neglected in the fifteenth and sixteenth century monastic life was the financial aftairs of the various monastic houses.

It cannot be said that all the monasteries were in financial difficulties, nor can it be claimed that all were weal thy, prosperous houses. Henry VIII might have
1. Ibid., p. 109.
2. Patterson, op. cit., p. 178.
3. Capes, op. cit., p. 155 . 
expected them to be strongholds of wealth and riches, but in some cases he ras sadiy disappointed. For the greater part, the monasteries were rich houses, but in certain exceptional cases it can be seen that some were in dire poverty and financial difficulties. The following description, although it was written about the Abbey of Glastonbury, might be applied to the majority of Fnglish houser: "It had immense wealth; every Wednesday and Friday it fed and 10 dged 300 boys; it was esteemed very highly in the neighbourhood and recelved large donations from the knights in the vicinity."I

In contrast we have those houges where, because of mismanagement on the part of the monks, they were forced to meet many diffcalties financially. Sometimes this trouble was due to the fact that the monks, or an ambitions abbot, might wish to increase the splendour of their possessions and add large, spacious buildings to their cloister. These were usually examples of beautiful and fine architecture, but they left the monks deeply in debt. ${ }^{2}$ others claimed that the obligation of housing travellers and rojal guests was too much of a barden to them financially. However, Archbishop Bourchier
1. Wishart, op. ait., p. 315 .
2. Capes, op. cit., p. 282 . 
examples the lack of money to other reasons. He said: "They waste the property, rights, goods, fruits, and revenues of their benefices of this sort, and vainly and uselessly consume them on forbidden and profane objects." The following can be found in the Register of John Stafford:

The finances of the house as well as the morals of the monks seem to have needed the abbot's attention, and we find in 1443 that he had to prosecute Bartholomew Downton of Iyllington in Dorset because of his unvillingness to give up his accounts when he was receiver in the county for abbot chynnock.?

We have other examples of poverty in monastic houses. "The Benedictine abbey of Tavistock in the fourteenth century was seriously troubled by debt, partly at least caused by an incapable and unworthy superior.n3 Apparently there were cases of genuine poverty. Thus the canons of Alguebelle wrote to the Bishop of Hereford: "They have had hard times -- their books and vestmenta are worn out, and they appeal for help from the bishop of Hereford. " 4

In some of the convents it was found that the superior, due to poor mangement, was leading the house into ruin. "She pinched the nuns and spent too freely

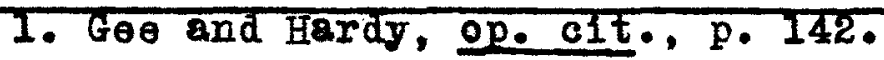

2. Holmes, op. cit., p. xl1.

3. Gasquet, Monastic Iife, p. 187.

4. Bannister, op. cit.. p. vi. 
on herself." "The abbess of Romsey mast not keop many doge or any monkeys, nor should she stint the nuns' food to provide for her own pleasures."l

Another factor that helped cause poverty in some of the houses was the tributes exacted by the papacy and the Crom. ${ }^{2}$ Bach year there was collected from the monks the king's first fruits and tenths, plus the money that the monasteries were obliged to send to Rome. The following itemized income shows the amount paid out to these various sources: ${ }^{3}$

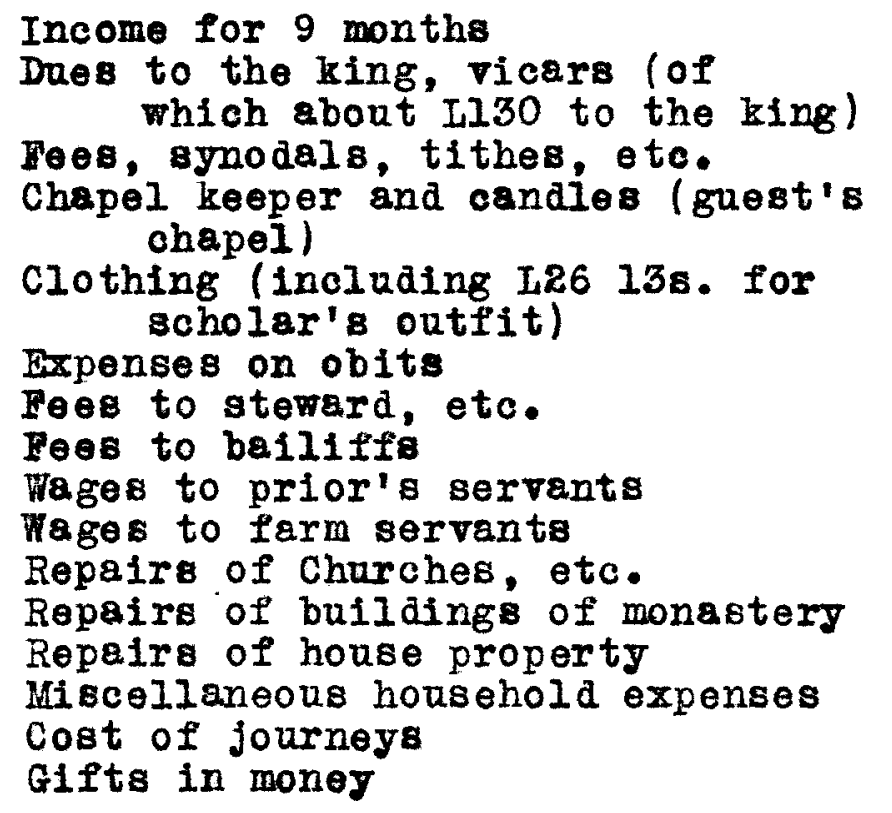
I $2202 \quad 10 \quad 0$

$\begin{array}{rrr}318 & 8 & 0 \\ 122 & 14 & 0 \\ 4 & 11 & 0 \\ 136 & 13 & 0 \\ 20 & 7 & 0 \\ 27 & 10 & 0 \\ 24 & 3 & 0 \\ 35 & 16 & 0 \\ 134 & 4 & 0 \\ 12 & 18 & 0 \\ 17 & 10 & 0 \\ 49 & 14 & 0 \\ 24 & 0 & 0 \\ 12 & 8 & 0 \\ 42 & 8 & 0\end{array}$

\footnotetext{
1. Capes, op. c1t., p. 303.

2. Patterson, op. cit., p. 184.

3. Gasquet, English Monasteries, p. 508. Priory of Huntingdon - for 9 months from Michaelmas 1517. Figures multiplied by 10 to give some sort of approximation to modern values. House consisted of a prior, 11 cenons, 34 servants. No mention is made of the amount sent to Rome.
} 
Farm repairs, miscellaneous farm expenses (of which threshing (20)

Bread bought for guest (bishop's $67 \quad 15 \quad 0$ visitation)I6 28 .

wine bought for guest (b1shop's visitation) I2 10s.

Goodsle bought for guest (bishop's Fuel visitation) I 9

Iights

Wheat, malt, barley, bought

stock bought

Iegal expenses

"Expenses of howshold as appereth

Debts paid by je kechyn boken

\begin{tabular}{rrr}
417 & 3 & 0 \\
$\frac{422}{1}$ & 10 & 0 \\
\hline 2210 & 15 & 0
\end{tabular}

Another manner in which monsatic wealth disappeared was the payment to officials for positions that they might bestow upon some favorite. A good illustration of this is the osse of W1Iliam Boston who was appointed abbot of Westminster in 1515. The records do not say that Cromwell appointed him, but shortly after his appointment he paid Cromell I $661,13 \mathrm{~s} 4 \mathrm{~d}$ and after his arrival at Westminster was still I 500 in debt to him and to the controller of the Royal Household.

Before the year was out the new abbot had shown his hand. Ten of the abbey manors were given away to raise money for this debt; Cromwell was made Janitor of the monastery, keeper of the Gatehouse prison, and Seneschal (or steward). As seneschal he could hold manorial courts all over the abbey estates, a privilege which was no doubt financially protitable. In the next year Cromwell took further tribute from the monastery in the shape of 60 years leaves of three manors and the right of presentation to oakham. Various other people connected with the royal household obtained similar benefita, including Anne Boleyn, the Iord Chancellor, and the Court physician. No 
attempts seem to have been made to gloss prer the traffic in abbey property and privileges. 1

A variation of this was the payment to the Crown of a certain sum of money for the span of time between the death of one abbot and the appointment of a new one. From the Additions to Adam of Domerham's Chronicle are some instances:

Redemptions of certain abbeys whon racant:

The abbey of st. Edmundsbury undereth 1200 marks for every vacancy, long or short; and the monka have made fine for I 200 .

The abbey of (Ulmo) 200 marks for each 4 months.

The abbey of St. Albans, for every vacancy of a year or less, 1000 marks; and if longer, then more in proportion.2

In the later years of English monasticism some of the monastic wealth went as bribes to save the houses from dissolution. After the commissioners visited many of the cloisters and sent in their reports, letters of the following nature came to Cromwell's attention:

'I submytt myselfo', wrote the abbot of Rewley, ' fulle and holle to jour mastershipp, as all my refuge, helpe, and socor is yn yow, glad of my voluntarye mynde to be bounde in obligacion of one handred powndes to be payed to your mastershipp, so that our house may be savyd.' Te may well believe that this proposal did not fall on deaf ears.3

\footnotetext{
1. RusseII, op. c1t., p. 15 .

2. Coulton, Iffe in Midale Ages, Vol. IV, p. 206.

3. R. G. Merriman, Life and Letters of Thomas Cromell, Vol. i, p. 168 .
} 
It offered Cromwell an excellent opportunity for private gain. It has been estimated that the monks paid out the sum of I $5,948,6 \mathrm{~s}, 8 \mathrm{~d}$ in an effort to save their houses from the dissolution. ${ }^{1}$ However, after these religious bodies raised huge payments to save themselves, they were treacherously destroyed anyway. Such was the case at the convent of pollesworth.

After those monasterles had procured an authorization to continue in exis tence and in sereral cases imporerished themselves paying the heavy fines exacted by the King, the latter me parliament pase another act - - which commanded the suppression of all monasteries. In this way, the King first got fines for exemption, and then the monastery itself.2

The life of the monastery was not always harmonious. Often times, as differences will arise in places of business or in families, there were disagreements and factions within the religious group which frustrated them from attaining the ideal monastic experience. The nuns of the Holy Sepulchre at Canterbury quarreled so much that they "must be kept in a dark room till they agree to live in peace."3 such was the case at the monestery of St. Alban's at the end of the fifteenth centary.

The abbot twice applied to the Crown, at an interval of sixteen years, for the arrest of an

1. IIIJegrin, op. cit., p. 2I.

2. Ib1d., p. 21 .

3. Capes, op. cit., p. 303. 
'apostate' monk, and in the same terms: 'Iike another son of perdition he goes about from town to town, and from market to market, more like a vagabond and an apostate than a monk, and causes in his travels the greatest scandal, as well to the order as to religion in general.' Bach of the two had been prior of a dependent cell; each had been sent as a commissioner to inquire into the conduct of the other; both were deposed and reinstated, and one at least confersed that he repented of the felse charges he had brought. There are many illustretions of such discord and intrigues in the annals of the smaller houses, as notably in Meaux in 1353. Bxcept in the Carthusian Order there was no chance of privacy for moody or impatient tempers, and the necessity of daily intercourse with uncongenial tastes and habits must have sorely strained the powers of self-control.1

Besides disputes within the monasteries there were oftentimes feuds between the various houses. For example the abbots of Westminster and St. Albans disputed the right of precedent in parliament for many years. Finaliy in 1417 , - . they transferred the quarrel to land in dispate between their several estates. One erected a gibbet on it $a .8$ token of his foudal rights; the other had it levelled to the ground 'by force of swords and axes.' Set up once more it was again demolished, while the tenants of the nelghbouring manors, 'for fear of their hides', steslthily made perambulations of the disputed ground and played thus at hide-and-seek for many years. . . the Abbot of St. John'a at Calchester sent, in 1399, 8 party of monks to Snape in Suffolk, who broke into the prior's house and burnt the deeds that were found there, and then lay in wait outeide, wounding his servants, borning his crops, and carrying off his stook. 2

This factious disorder can be best seen later when

$$
\text { 1. Capes, op. CIt•, p. } 2950
$$

2. Ibid., p. 294. 
the commissioners were sent to investigate the homo of the friars. At that time the royal agenta would have had trouble in some monasteries at least, getting the truth (if the truth had really been the goal), since many of the inmetes deliberately lied or made up slanderous tales about some of their brethren whom they happened to dislike. Sometimes members of one monastic order or house would elaborate on and then repeat as the truth detrimental storles that they had heard of a neighbouring house of which they might heppen to be envious. Although this was far cry from their religious teachings, they were conveniently laid agide for the time being. Even though the quotation, united we stand, divided we fall" is a motto of an Amorican state government, the same idea could have been applied very satisfactorily to organizations in the fifteenth and sixteenth centuries. It wos even true of the monastic orders, but they failed to realize that "in union there is strength." Instead they allowed silly personal differences and petty disputes among the brethren in the houses to divide the houges themselves. If they could not live together peacefully before, how could they, divided, expect to withstand the royal opposition and propaganda that they had to face during the reign of Henry VIII? Iong and fierce has been the "battle of words" 
that historians have waged over the superstitions and relics held by the monssteries. The Protestant aympathizers have called the ololster "crades of superstitions" and have condemned all their images as money-making fakes. Whereas the catholic-inclined group hasten to the defense of the monks by claiming that these relice were not used but hed long been discerded before the dissolution; or else they were used with the upmost trust and sincerity and with no 1dea of deceiving the people.

One of the most debatable of these relics was that known as the "Blood of Hagles", which was said to have been the Blood of Christ. It was sapposed to have had certain miraculous powers, such as the ability to make itself invisible and visible. The monks were later accused of all sorts of trickery in connection with this mirecle-working wonder. In the following letter to Cromell from the abbot of Heyles we can see that the abbot himself realized the hoax thet was being played on the people, and whether earnestly or not, we do not know, he attempts to free himself of the responsibility of continuing to allow it to be shown.

'It is not unknown unto your honour how that there is in the monastery of Hayles a 'blood', which hath been reputed as a miracle a great sesson. And now I come to tell your lordship plainly that I have a conscience putting me in dread lest idolatry be comitted therein, giving the very honour of the blood of Christ to that thing, which I cannot tell 
what it is. And, having this conscience I was and am wonderouely perplexed: for to put it away of my own authority, seeing it hath been allowed there to be showed to such as seek for it, I feared to do lest I should condemn self to be guilty in misusing it, as changing and renewing it with drakes blood, wherein I offer myself to suffer the most shamoful death that ever man suffered if over it may be proved that it was either changed, renewed or ever looked upon to try what it is, to m knowledge, but is there still, as far as ever I can learn or know, as it was brought thither. And, there is one monk alive nigh eighty yesrs of age, who hath kept it almost forty years. And he will (as he sags) upon his life make the same answer. And for discharge of my orm conscience in aroiding of ldolatry and to save my honesty towards the world I do most earnestiy beseech your honour to send hither your commission by whom it shall please you to examine my truth and honesty in this manner upon danger not only of my office and suppression, but also of my life, if I be found guilty in any word that I have said; and then further, by your authority, to order that blood that it may be nor more noted to minister occasion of idolatry.' (R.O. State Papers, Dom., $1538)^{1}$

As a result of this letter from the abbot of

Hayles, the King sent Bishop Latimer, the prior of

Worcester, the abbot, and Richard Iracy, Esq., to the abbey on October 4, 1538 to examine the "Blood." In a report of their findings which was adressed to cromell, they otated:

1 certain aupposed relic called the blood of Hayles, which was inclosed with a round beryl, gernished and bound on every side with silver, which we censed to be opened in the presence of a great multitude of people. And the said relio we caused to be taken out of the said beryl and have viewed the same being within a little glass. And we also tried the same according to our powers 
wits and discretions by all means and by force of the view and other trials thereof we think deem and judge the substance and matter of the seid supposed relic to be an uncterous gum colored, which being in the beryl oppoared to be glistening red, resembling partiy the colour of blood. And after we did take out part of the said aubstance and matter out of the glass then it was apparent glistening yellow colour like amber or base gold, and doth clesve to as gum or birdlime.'l

Lodern writers seem to agree that the blood was in reality that of a duck, which was renowed at certain intervals by monks appointed to that certain duty. The substance was kept in a crystal, very thick on one side and transparent on the other. If a wealthy men came to confess his 81ns, the thick side was displayed until ho had paid for a number of masses, then suddenly, a reformation took place. "'one in a secret place behind the altar, near which the relic was placed, turned the thin aide, and then the blood appeared." ${ }^{2}$

There was an abundance of other superstitious relics, al though probably none as well known as the "Blood of Hayles." For ingtance there was the famous Road of Grace, or Road of Boxley as it was sometimes called, which was displayed at Boxley abbey. It was a figure on a crucifix whose eyes and mouth miraculousiy opened and shut. Cromell's agent, Geoffrey Chambers

$$
\begin{aligned}
& \text { 1. Ibid., pp. 537-538. } \\
& \text { 2. Ib1d., p. } 539
\end{aligned}
$$


describes it as follows: ".. certen ingynes and olde wyer wyth olde roton stykkes in the backe of the same, that dyd cause the eyes of the same to more, or stere in the hede thereof lyke unto a lyrelye thing." Il The image was seized by Cromrell's agents and later exhibited to the pablic in Kent, Meidenstone, and Iondon. Geirdner excuses this relic by saying that it was merely an "oldfashioned toy." The description of it by cromell's commissioners shows that it was full of old wire and rotten sticks and therefore, must have been a thing thet the people had worshipped many years before. 2

Besides these two outstanding ones there were other less famous relics in the monasteries. A traveller in 1509 left an account of those that he saw at Canterbury, which he said were shown chiefly to arouse the many pilgrims' faith and thereby increase their gifts.

He saw there a fragment of the robe of Christ; three splinters from the crown of thorns; a lock of Mary's hair; a shoulder blade of simeon; a tooth of John the Baptist; blood of the apostles John and Thomas; part of the crosses of peter and Andrew; a tooth and finger of St. Stephen; some hair of Mary Magdalene; a lip of one of the innocents slain by Herod the Great; the head of Thomas a Becket; a leg of st. George; the bowels of st. Iewrence; a finger of St. Urban; a tooth of St. Benedict; bones of st. Clement; bones of St. Vincent; bones of St. Catherine the Virgin; a leg of Mildred the Virgin; and a leg

$$
\begin{aligned}
& \text { 1. Merriman, op. clt., Vol. I, p. } 174 . \\
& \text { 2. Poliard, op. cit., p. } 380 \text {. }
\end{aligned}
$$


of a virgin called Recordia. He saw besides in the cloister, a fountain which flowed at times with water, at other times with milk, and at still others with blood. It had been five times changed to blood, and just before his visit it had been changed to milk. 1

When Cromell's agents made a survey of the houses, they listed beside the name of each monastery they visited the superstitions that they found there. The following are only an example of the many superstitions that they found and that they listod in the comperta:

Arthington - . - Founder Henry Arthington. Rent 20 marks. Superstition the girdle of st. Mary.

Basedale . . . Superstition there that they had the Virgin's milk. Founder Sir Raleigh Iveres. Rents 1811.

Nonneburnham . . Founder Iord Dakers. Rents 711. Here they have part of the Holy cross.

Haltemprise - . Founder the Duke of Richmond. rents $104 \mathrm{Ii}$. Here is a pilgrimage to Thomas wake for fever and in veneration they have the arm of st. George and part of the Holy Cross and the girdle of st. Marie healthful for childbirth (as is thought).

Koldham - . . Here they have part of the Holy Cross and a finger of st. Stephen which is lent to lying-in women.

Arden . . . . Founder the Duke of Norfolk. Rent 20 marks. Here women go to the Image of st. Brigett and offer for cows lost and 111 .

1. Geikie, op.cit., p. 14. 


\begin{abstract}
Nunkeeling . . . Founder the King. Rents $36 \mathrm{li}$. Here is part of the Holy Cross.

Clementhorpe . . Founder the Archbishop of York. Here also they have milk (as believed) of the Blessed Mary in veneration.
\end{abstract}

Fountains . . . Six seek relesse. They have a girdle of st. Mary (as ia believed). Founder the Archbishop of York. Rents $1200 \mathrm{Ii}$.

Pontefract . . . Here they have in veneration Thomes, Duke of Lancaster, and his girdle, which is (es is believed) safe for lying-in women and his hat for pain in the head. Founder the King. Rent 330 11. The house owes $201 i$.

Selby . . . Here also they have the girdle of the Blessed Mary as is pretended. sounder the King. Rent 8800 marks. Owes 30011 .

sinningrhwaite - Here they have the arm of st. Margaret and the tunic of st. Bernard as is believed safe for the lying-in women. Founder the Earl of Northumberland.

st. Leonard's, York Here they have the arm and IInger of st. Leonard in reverence and his image. Founder the King. Rents 7 marks. 1

On August 24, 1431, the Bishop of Dogmersfield ordered to have read in the cathedral at wells and in all of his diocese a charge against sorcery, lot drawing,

\footnotetext{
1. Clay, op. cit., pp. 16-18. ihese are only a few of the many superstitions mentioned, not only in the Comperte, but in many other references.
} 
incantations and any other prgan superstitions. ${ }^{1}$ won almost one hundred yoars later the agent of hemry VIII visited the cloisters they still found in some man superstitions. The Commissioner John Ap Rice writes to Cromell concerning one monastery that he visited:

'Among the relice we founde moche vanitio and superstition, as the coles that Saint Iaurence was teated withail, the paring of Saint Edmund's naylies, and divers gkuiles for the hedache; pieces of the holle crosie able to make a hole crosse of; other reliques for rayne and certain other superstitiouse

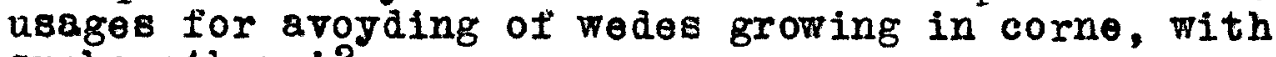
suche other.' 2

It is difficult to tell just how readily the people believed in these old relics, but it is certain that there was an abundance of them in many monasterfes. Had they not been profitable to the houses, they would hardly have been so numerous. They were displayed to the people as miracle-working wonders which could do anything from curing pains in the head, to making lost cows return home. For the most part, the monks realized the hoaxes that they were playing on the people. James, a carthusian monk of the later part of the fifteenth century wrote: "There is so much superstition. There are so many of the worst and most scandalous practices in the church .. . all religion seems wellnigh choked, as if the enemy of souls had sown

$$
\begin{aligned}
& \text { 1. HoImes, op. cit., } \bar{p} \cdot \overline{I V} \cdot \\
& \text { 2. Wright, op.cit., p. } 85 .
\end{aligned}
$$


tares over the wheat.'"l However, the money received through gifts to these "holy relics" was just as valuable to the monastery as any other source of inoome. After all the King should not be accused of being the only mercenary soul in sixteenth century fingland!

Institutions, like people, usually are elther progressive or retrogressive. The progressive ones live, the others lag along for a span of a few years and pass out of existence. To be vitelly alive it is necessary to be alert and progressive, but the monasteries failed to understand this reasoning. As has been pointed out before, one of the monastic activities was that of education. However, by the sixteenth century they were neglecting not only the education of the children entrusted to their care, but also the education of their ow members. is a result many of the monks could not read; their books, chronicles, records, and sermons suffered from neglect, and their wondrous educational work of the past was lost to the morla.

The cloisters failed to send forth writers such a Matthew Paris. As schools, libraries, and storehouses of culture of by-gone days, the monasterles were useful to civilization. However, as unprogressive places, abounding 
with superstitions, they were no longer an asset to Fngland. The people were beginning to feel that monasticism was becoming out-dated. "Jandland, in holdIng up the Ploughman as one who had the ideal life, had in fact pronounced the deth-knell of monasticiem. The coming age looked on an active life as superior to one of contemplation and prager." 1 by the writings of the time we oan tell that people were becoming disartisfied with this religious group. Even the friars had declined so in their moral and intellectuel life that their illustrious forefathers, Albertus Magnus, Thomas Acquinas, Duns Scotus, and William of Ockham would have turned in their graves had they known. A poem of that period shows the feeling towards the friars:

'All wyckedness that men con tell Rynes ham (reigns them) among Ther ahal no saule (soul) have rowme (room) in helle, of frers ther is suche throng. ' 2

By the beginning of the sixteenth century some of the duties and activities that the monks had once so nobly performed were gradually being taken over by other groups of poople. Tro of the most important of these activities were, the care of the poor and the hospitality extended to traveliers. Before this time the unfortunates had

1. Patterson, op. cit., p. 184.

2. Ibia., $p .184$. 
depended solely on the monks for donations and alms. However, at the beginning of the modern period, commantt1es were becoming conscious of this need and mindful of the fact that it was thoir duty to do somothing about it. As result we have the Ilizabethan and other poor laws passed and finally the assumption of the care of the poor by the state.

Iikewise, the monastic duty of hospitality has been assumed by other more modern institutions. Thereas, in olden days the monasteries were the only places to stop on weary journey over the countryside, by the beginning of the sixteenth century inns and hotels were apporing to replace the monsatic guest house.

This is indeed a changing world! For many years the monks had performed their duties and performed them well. But there finally came a time when this was no longer true, and the industrious, intellectual and really religious monastic life of the past was only a memory. This was not a rapid change. Let us compare the monasteries to beautiful cathedral. The many reasons mentioned which caused the downfall of the monks were I1ke so many tiny, bat destructible termites. These creaturea very slowly bored and cut into the foundation and supports of this building. Nothing done to stop the deterioration and the structure continued to grow 
weaker and weaker. One day an "outside force" caused the collapse of this grest edifice. Although, among the wreckage there were some parte which were found to be as solid, as strong, and as beautiful as they had been the day they were placed there, they nevertheless had to be cleared away with the rest of the debris. Although they were strong, they were not strong enough to counteract the weakness of the other parts of the cathedral. Poople from the countryaide around came to view the wrock and blamed the "outside force" for the damage done. However, had the whole cathedral been as strong and as perfect as some of the parts found among the wreckage, and had not many of the once beatiful arches and columns become rotten and devoured, no matter how hard this "outside force" had pushed, the building would have stood, as majestically and as nobly as it had always stood in the past. 
CHAP TER VII

UNRELIABIIITY OF BVIDBHCE FOR THIR SUPPRESSIOH 


\section{UNRELIABILITY OF EVIDENCE FOR THE SUPPRESSIOH}

"When alle tresores arem tried, trewthe is the best."nl

After Henry VIII detinitely decided to bring about a dissolution of the religious houses in England, there had to be some evidence or proof, so that his actions might be justified. How, or by whom this evidence was obtained was not so important as it was to have the meterial there in case public opinion doubted the monarch's actions. The mere possession of such condeming evidence was justiIication in itself; its authenticity dared not be doubted. Therefore, in 1535 Cromwell, acting for the King, sent out Commissioners or agents to visit many of the monastic houses and to bring back reports on existing conditions therein.

At the summons of the Commissioners, clerks, registrars, receivers, auftors of preiates and clergymen were bound to appear before them and give all the necessary information, and the commissioners were to send in their returns to the Exchequer not later than in octabis Trinitatis 1535.... The Commisioners were sent to every diocese, shire, and popalous place in England and Wales. . . The Commissioners are to inquire into and record the names of all the abbejs, priories, monasteries and other religious houses and to inquire into all the Iinancial and internal affairs of the house .

\footnotetext{
1. G. C. Couton, From st. Francis to Dante, title page.
} 
When all the locel returns were completed, all the sab-commissioners of the diocese were to meet together and compile one general book for that diocese. - Phe commisioners rere to hand the general book to the Exchequer. 1

Unfortunately, however, these Commissioners were not men who found "truth the best of all treasures." They recognized the task to which they had been assigned. This was not really a survey being made to ascertain honestly the usetulness of the old religious strongholds. Hor was it a commission to discover the weaknessea and immoralities of the cloisterers for the purpose of remedying the 8ame. This comission had one purpose and one purpose only -- that being the king's purpose. "The king's parpose was rather to find a cause for appropriating the possessions of the monasteries than to mend their morals." 2 Even though it has already been said that many of the inmates of the monasteries had fallen far below the standards established for thom, and the majority were in s real noed of some drastic and immediate reform, the fact mast be admitted that the trial they recoived at the hands of Cromell's agents was not a fair one. There is too much evidenoe against the Commiseioners themselves to prove that they brought back true accusations. one factor againgt them was the time element.

$$
\begin{aligned}
& \text { 1. Savine, op. cit., pp. 3-5. } \\
& \text { 2. Liljegren, op. cit., p. } 19 .
\end{aligned}
$$


A thorough investigation into all the aftairs of the monasteries visited was a task, which if done accurately, would have taken a very long, drawn-out time. To inquire into all the financial affairs of the cloister, to record the names of the inmates, the tenents, servants, etc., and the possessions of a house, to question the religious brethren and register all complainte made, were all tasks which could not be hurried through in a few hours' time if they were to be done carefuliy and justly. This wos slow, tedions job, which required patience and above all an unlimited number of hours to accomplish. However, it was not regarded as such. For example, in the diocese of York, ninety houses were visited in a fortnight. 1

The second evidence of the unreliability of this material gathered for the suppression was the very character of the men who made up the commission. They were a sorry lot indeed, to be sent out on mission of this nature. They were men who, in order to accomplish the task to which they had been assigned, would stoop to any means. The chief Commissioners were Layton, Leigh (Iegh), and Ap-Rice, all three men who knew what was expected of them and ambitious enough to see that it was done to please their superiors, regardless of the methode

$$
\text { 1. Constant, op. cit., p. 162. }
$$


ased. "Fuller probably sums up the character of these visitors correctly, thet they were men who understood the mesage they went on, and would not come back without a satisfactory answer to him that sent them.'nl It has also been said of them:

'Most of the persons whom he [Cromell] used as his agents in the business were unprincipled mon for whom not word of good can be justly said; and most of those who encouraged and assisted the king in the dissolution did so for selfish objects, and for seltish objects alone.' 2

The Commissioners used verious methods to get the desired evidence. "But leigh was foremost in a policy of laying down of severe regulations for the monks, binding them by antiquated restrictions which it had long been impossible to maintain. ${ }^{3}$ The unsubstantial character of Cromell's agents and, therefore, the questionable methode used to extort the desired information, would give evidence to the unreliability of many of their reports. "The 'Commissioners found means', as it has been significantly stated, 'to make divers monasteries obnoxious.'"4 Thus evidence acquired in such underhanded methods by characters who made littlo distinction between right and wrong can not be accepted as authoritative.

1. Beckett, op. clt., p. 144.
2. Constent, op. eit., p. 164.
3. Gairdner, op. cit., p. 164.
4. Merriman, op. cit., Vol. I, p. 167.


One of the most successful ways that the

Commigsioners found to secure the desired evidence was to play upon the dissenting groups within each house. In every cloister there could usually be found a certain number who had some ill-feeling towerds their brethren, or as it usually happened, towards the superior. If these discordent individuals could be appealed to, and they usually could easily enough, then they would offer testimony as to the ill-repute of the house. Since this testimony was offered by brethren in a spirit of vengeance, it certainly could not be counted on as very reliable.

The spirit of faction and disorder within the conventual household was far more fatal to its usefulness and health. Such dissensions had not been unknown in earlier jears; for the monks could not leave behind them at the cloister gate their notural infirmities of temper, but they became more frequent and intense, as life grew more self-indulgent and discipline more $18 x .1$

Many years before the dissolution, the bishops used to use this same policy that the Commissioners later found so successful. They formed a regular secret-spy system among the uncongenial cloisterers, who would report to the bishop all the gossip of the house.

The Bishop of Iincoln seems to have kept a regular party among the canons of Leicester, the members of Which furnished him with gossip about the abbot, and who looked to the bishop for preferment. Hugh Oliver, prior of this abbey, was continually running off to

1. Capes, op. cit., pp. 294-295. 
Iondon or to the bishop on this errend, trying to work the resignation of the abbot in the hope of succerding him.1

Later, when Crowell's agents visited the monasteries, they used these same tactics. When they called the different members of the house in for questionIng, they were offered ohance to tell anything about their brethren. To complicate matters more, those dissenting members who had evidence againgt their aperiors had the right to appeal to cromwell. They could petition him with their evidence and it is most certain thet their petition did not fall on deaf ears.

One monk wrote to the Vicar-general that the inmetes of his home cared nothing for true religion, but came to matins 'as drunk 28 mice and played some at cards, some at dice' . . . and finaliy imparted the significant piece of information that Cromell's visitors had ordered him to write these opinions to headquarters. Another John Placett by name, sent cringing letters to the Vicegerent begging that his zeal in advancing the new doctrines and in reporting those who opposed them, might be rewarded by ofticial exemption from rising at midnight and from observing the customary fasts.2

The old proverb, "a chain is as strong as its werkest link" held true in the sixteenth century. How conld the cloisters steol themselves for the delage to come if individual momber were traitors within their own houses? The selfish persons who could not forget their

$$
\begin{aligned}
& \text { 1. Baglierville, op. cit., p. 75. } \\
& \text { 2. Merriman, op. cit., Vol. I, pp. 167-168. }
\end{aligned}
$$


petty differences in the face of nation-wide destruction were as much to blame for the terrible reports as Henry'a agents. They deliberately helped to create and circulate many of the degrading stories which the Comntssioners handed in to the crown. Therefore the dis senting elements within the monasteries helped to bring sbout their own downfall and destruction.

If the agents of Cromwell were unreliable reporters, Iittle more can be said for their leader and director. Cromell himself was certainly ambitious and selfiah. Admittedly Henry' ohief general in this monastic war, and direotor of the Commission which was sent out to bring back incriminating evidence ageinst the religions, Cromell, nevertheless, was not above taking bribes from the ene camp to save certain houses. Here we have the leader of the movement to dissolve the houses taking bribes to save them from dissolution. Along with the material which could doom the clolsters to destruction came letters of a different nature, offering cromell a chance for private gain should he intervene in their behalf and save them from the dissolution. For instance, the Abbot of Rowley wrote: "I submit mayself full and hole to your mastership, as all my refuge, help and soccour in you now, glad of my voluntary mind to be bound in obligation of I 100 to be paid to your mestership, so that our 
house may be sared."nl It is not likely that the

numerous proposals of this nature that Crompell received were disregarded. In 1536 after Henry had ordered the dissolation of the smalier houses, Cromwell intervened in the behalf of certain places. Some of these monasteries neglected to reward him for his trouble, but he soon reminded them that a due reward was expected and should be seen to immediately. The two letters following are examples of ach high-handed bribery.

Cromell to the Prior of St. Falth'a R. 0. Cal. Xi 484 Sept. $23 \quad 1536$

Right wellbeloved In God I Recommend me to you etc., the cause of writing at this time is thet for $8 \mathrm{~s}$ much as it please the king if his Regal power to take Reformetion of all and singular houses of Religion within the diocese of Norwich like as his Grace has done. In other pleaces and For the absence of Religion and excesses of living (some) shall be disposed of the which your house was b1lled and named to be on that not withstanding by the labor of jour Friends made to me with my diligences your house is taken out of the king's books and with out danger and so shall Remain till the Return of this may chaplain of woys Report hangs your Information to the cownsell wome I will thet your shall Receive as my trusty chaplain and this pleasure considered as I have deserved to look to my pains and to the berer here of as you would have Further pleasure scoyd off me In like matters For the maintenance of your house I am the more bolder to write by cause that I has been sumtws to me of late as the berer here off can express more plainly to you. Written at Iondon the XXIII day of September $\mathrm{By}$ me Thomas Cromwell Add. To the Reverent Father in God prior of saint Faiths be thys d.d.2
1. Herriman, op. c1t., Vol. I, p. 168.
2. Ibid., Vol. II, p. 32. 
Cromell to the Prior of Coxford

$$
\text { R. O. Cal. XI } 485 \quad 1536
$$

Right Reverent Father In God I Recommend me to you etc. and the cause of my writing at this time is this For as much as it plesse the king of his Regal power to take Reformation of all and singular houses of Religion within this his realm For the abbwcyon of ther living and some shall be disposed of the which your house was named jet not withstanding by the Instance of your Friends, till the Return of this Chaplain and kinsman I do keep you harmless werefore I will that you receive him as ye would me if I were present. Purther I will this premess considered wich belongs to the wealth of your house that you must do me some pleasure which is to lend me xl1 the which shall be paid you again, and For your payment you shall receive a bill of my hand wherein it set no sum but loke how myche as yo delouer so myche to write In and this day shall be Redy to keep you out of danger as the bearer here of can show you more plainly namore to yow brethet you look to the pains of this bearer. Written at Iondon

\section{By me}

Thomas Cromell

Add. To the Reverent Father In God prior of Coxford by this d.d.I

During the entire commission the agents were never ellowed to forget the purpose of their tasks and it is most certain that pressure was brought to bear to see that their memories were often refreshed.

The men who in 1535 controlled the machinery of the state attached great importance to the work of the Commissioners and therefore wished to direct that work even in matters of detall. The Commissioners of 1535 felt the heary hand of the Government throughout the wole of their work; they were in constant correspondence with it. 2

$$
\begin{aligned}
& \text { 1. Merriman, op. cit., Vol. II, p. } 49 . \\
& \text { 2. Savine, op. cit., p. 5. }
\end{aligned}
$$


Pinally the work of the Comnission was completed and turned over to Henry and Cromell for further use. All of this material that the Commissioners brought back was put together into a huge collection known as the Valor Ecclesiasticus, or Commissioners Reports. Not all English cloisters were visited, but the conditions found in those that were are recorded in this tremendous work. "The Commission reported about one-third of the houses to be fairly well conducted, some of them models of excellent management and pure living; but the other twothirds were charged with looseness beyond description." (From Commissioners Reports) ${ }^{2}$

Besides the Valor Ecclesiasticus there was a smaller collection known as the Comperta, which dealt mainly with the immoralities reported to be found within the cloisters.

There remain in the Record office certain documents called Comperta, which are a sort of tabulated statement of the immoralities imputed to the religious persons and their houses. These cannot be regarded as historically reliable; but to find sutficient evidenee against the purity and discipline of the 'religious' we need not travel beyond the bishops' register, the entries in which are above suspicion, and which go far to substantiate some of the worst accusetions. 3

1. It is important to note that the commssioners admitted that one-third of houses were well-conducted.

2. Wishart, op. eit., p. 317.

3. C. G. Perry, History of the Reformation in Fingland, p. 32, footnote 1 . 
The Comperta might be referred to as the "tabloid" sheet of the Commission. It disclosed all the scandals that the Commisioners could conjure together during their work. It listed by the name of each house visited the crimes committed and the superstitions found therein. It has been said of the Comperta: "This is of such a character that it is not entirely fit for publicetion." The following are a fen examples from the comperta.

Clementhorp -- Founder the Archbishop of York. Here also they have milk (as belleved) of the Blessed Mary in veneration and here is made pilgrimage to Saint Sithe.2

Thickhoed -- Matilda Chapman seeks release from religion. Founder John Aske. Renta I 23.3

Fountains -- six seek release. They hare girdle of St. wary (as is believed). Founder the Archbishop of York. Rents I 1,200.4

This edition of the Comperta has been censored to make it fit for publication. In its original form it was said to contain many shady tales of monastic wantonness.

Besides the Velor Ecolesiasticus and the Comperte, there was supposed to have been another publication about the clolstered groups. This much-debated work is referred

1. Clag, op. c1t., p. 13 .

2. Ibid., p. 17.

3. Ibid., p. 17 .

4. Ibid., p. 18 . 
to as the Black BoOk and was even worse in its accusetions than the Comperte. However, it is now questioned whether such a book ever existed. Some authorities claim: "The Black Book was a mere invention of a later age."l others assert: "The original indictment againgt the monasteries called the Black Book has been destrojed or lost." 2 The catholics claim thet the protestants destroyed this book so that the folse eviaence on which they acted to dissolve the monasteries might never be known. Others say that it was burned years later by an order from Queen mary. It has nover been definitely proved whether such a work did or did not exist. Monastic sympathizers claim that the religious were undaly condemed.

These monastic ruins . . were peopled by men and women who resembled mostiy our ordinary selves, and Who lived, if not strictly according to the Rule, at least with more regularity than the average of their fellow men and women outside... Among all the lay critics, there were not many who would face the ordinary requirements of monastic discipline. 3

This mey have been true, but the religious had pledged themselves to Iive better lives than others, by more strict rules and regulations. Some may have been living

1. Patterson, op. cit., p. 22\%.

2. Perry, op. cit., p. 32, footnote 1.

3. Coulton, Medieval Panorama, p. 281. 
with "more regalarity than the average of their fellow men and women," but the many were not. The many were serving as poor examples for the religious way of life. They were not only degrading themselves but they were puling down the monastic structure with them. Eren the vilest criminal deserves a fair trial. Regardless of the innocence or guilt of the monks, they too, at least were due a fair examination. Such was not to be their lot, however. Instead, their homes were visited by men who knew the job expected of them and did it accordingly. True, many of the monasteries were corrupt and needed some kind of reformation, but the ovidence used in suppressing them was certainly unreliablo. The material turned in by Cromell's agents was suited perfectly to Henry's purpose. Cromell had chosen his men well. Their propagande accomplished its work very spccessfully, but the king had "hit below the belt" in winning his fight. 


\section{BIBLIOGRAPHY}




\section{BIBLIOGRAPHY}

Bannister, Arthur T. The Register of Charles Bothe Bishop of Hereford $(1516-1535)$. Hereford: W1180n and PHIIIPE, 1921.

Baskerville, Geoffrey. English Monke and the Suppression of the Monasteries. How Haven: Yale University Press, 193\%. (Justifies Henry's actions)

Beckett, T. H. The Bnglish Reformation of the Sixteenth Century. Iondon: the Religious Iract society, I890. TPro-Anglican)

Belloc, Hilaire. How the Reformation Happened. New York: Robert M. McBride and Company, 1928.

Capes, W. W. The Fnglish Church in the Fourteenth and Fifteenth Centuries. London: Macmilian and Company, 1900. (Reotor of Bramsholt -- pro-Anglican)

Cheney, C. R. Ipiscopal Visitation of the Monasteries in the Thirteenth Century. Manchester University Press, 1931.

Cheyney, Edward P. A Short Hlstory of England. New York: Ginn and Company, 1904.

Cheyney, Bdward P. Readings in English History Drem Irom the Original Sources. Hew York: Ginn and Company, 1908.

Child, Gilbert W. Church and State Under the Tudors. Iondon: Longmans, Green and Company, 1890. (Bxeter College, oxford -- pro-Anglican)

Clay, John W., editor. Yorkshire Monasteries Suppression Papers. Yorkshire Archaelogioal society, 1912.

Collins, Wliliam E. The English Reformation and Its Consequences. Nê York: B. and J. B. Young and company, 1899. (Professor of Rcolesiastioal History at King's College, London) 
Constant, G. The Reformation in England. New York:

Shood and Ward, Inc., 1934.

(Very pro-Catholic)

Coulton, G. G. From Saint Francis to Dante. Iondon: Barnicott and Pearoe, 190\%.

Coulton, G. G. Ifife in the Midale Ages. New York: Macmilian and Company, 1931.

(Good documents of the midale ages)

Coulton, G. G. Hedieval Panorama. Hew York: Macmillan and Company, 1938.

Coulton, G. G. The Medieval Scene. New York: The Macmilian Company, 1931.

(Fellow of St. John's College, Cambridge, pro-Anglican)

Crabites, Plerre. Clement VII and Henry VIII. Iondon: George Routledge and Sons, Itd., I936.

Creighton, Mandell. Historical Iectures and Addresses. London: Longmans, Green and Company, 1903.

Dietz, Frederick C. A Political and soolal History of Bngland. New York: The Macmillan Company, 192\%.

Erasmus, Desiderius. In Praise of Folly. Iondon: Gibbinge and Company, Itd., 1900.

Hequiros, Alphonse. Religious Iife in Fngland. Iondon: Chapman and Hail, $186 \%$

Fish, Simon. A Supplication for the Beggars - 1529. London: Southgate, 1878 .

Flick, Alexander C. The Decline of the Medieval Church. New York: Alfred A. Knopf, 1930 . (Anti-monastic)

Froude, James A. History of Fngland from the Fall of Wolsey to the Death of Elizabeth, Vol. I. New York: scribner, Armstrong and Company, 1873.

Gairdner, James. The Inglish Church in the sixteenth Centuxy. Iondon: Macmilian and Company, 1924. (Pro-catholio) 
Gasquet, Abbot. English Monestic Iife. Iondon: Methuen and Company, 1904.

(Pro-Catholic)

Gagquet, Francis A. England Under the 0ld Religion and Other Eqays. London: G. Bell and Sons, Itd., 1912. (Pro-catholic)

Gesquet, Francis A. Henry the Eighth and the Anglish Monesteries, V01. II. Iondon: John Hodges, 188\%. (Pro-(atiolio)

Geo, Henry. The Reformation Feriod. Iondon: Methuen and Company, I919.

(Master of University College, Darham. If anything a little pro-Anglicen, but gives the cetholic side of the story)

Gee, Henry and Hardy, William J. Documents Illustrative of Fnglish Church History. London: Hacmillan and Company, 1896.

(Good document material)

Geikie, Cunningham. The English Reformation. How York: D. Appleton and Compeny, 1879.

Graham, Rose. An Essay on English Monasteries. Iondon: The Historiogl As800iation, I933. Leatiet No. 32.

Hackett, Francis. Henry the Eighth. New York: Horace Iiveright Inc., 1929 .

Hague, Dryson. The Church of England before the Reformation. Iondon: Hodder and Stoughton, 192\%. Thector of St. Paul's Churoh, Nova Scotia, proAnglican)

Holmes, Thomes S., editor. The Register of John Stafford. Iondon: Harrison and Sons, 1915.

Innes, Arthur D. Fnglend Under the Tudors. New York:

G. P. Putnam's Song, I9EI.

(Pro-Anglican)

Inventories and Account Rolls of the Benedictine Houses of Durham. Durham: George Andrews, 1856.

Kitchin, G. W., editor. Compotus Rolls of the Obedienteries of St. Swithun's Priory, Winchester. London: SImpkin and Company, Ltd., 189z. 
Iiljegren, S. B. The Fall of the Monasteries and the Social Changes in Gngland. Lund and Leipaig: Hasan Ohls8on, 1924.

(Tries to present both sides of the question)

Madge, F. T. and Chitty H., editor, Registrum Thomas Nolsey. Oxford University Press, I926.

Martineau, Arthur. Church History in England. New York: E. and J. B. Young and Company, 1880.

Mattingly, Garrett. Catherine of Aragon. Boston: Iittle Brown and Company, 1941 .

(Pro-Catholio in that he tries to make jou think that everything Catherine did was right)

Merriman, Roger B. Iife and Letters of Thomas Cromell, V018. I, II. OxIord: CIarendon Press, I90Z.

Palmer, R. I. Fnglish Monasteries in the Midale Ages. London: Constable and Company, Itd., 1930.

Patterson, M. W. A History of the Church of England. Iondon: Longmañ, Green and Company, 1929. (Fellow and tutor of Prinity College, oxford -pro-Anglican)

Perry, George H. History of the Reformation in England. Iondon: Iongmans, Groen and Company, 1895.

Phillips, Thomas. The History and Antiquities of Shrevsbury, Vol. I. Printed and published by the editor, Providence Grove, near Shrewsbury, 1837.

Pollard, A. F. Henry the Eighth. Iondon: Iongmans, Green and Company, 1925.

(Fellow of AII Souls College, Oxfora, pro-Anglican)

Read, Conyers. The Tudors, Personalities and Practical politics in sixteenth century england. oxiord University Press, 1936.

Russe11, A. I. N. Nestminster Abber, the Story of the Charch and the Monastery. Iondon: Chat to and indus, 1934.

Savine, Alexander, English Monacteries on the Eve of the Dissolution. oxford: Clarendon Press, 1909. Tood statistical material; tends to uphola the Catholics) 
Spence, H. D. M. A History of the English Church. London: J. M. Dent and Company, I900. (Dean of Gloucester - - but rather fair in his treatment of the catholics)

Strype, John, Memorials of Thoma Cranmer, Vol. I. Iondon: George Routledge and Company, 1853.

Stuckert, Howard M. Corridies in the English Monesteries. Philadelphia: University of Pennaglvania, 1923.

Faunton, Ethelred I. Thomas Wolsey Legate and Reformer. London: John Lane, I902.

Wakeman, Henry 0 . The History of Religion in England. Iondon: Rivingtons Water100 PIace, 1815.

Walker, J. W., oditor. Abstraets of the Chartularies of the Priory of Monkbretton. Record Series VOI. LXVI, Yorkshire Archaological society, 1924.

Warner, Charles D. The World'B Best Literature, Vol. IIV. New York: The International soclety, 1896.

Warner, Ferdinando. The Bcclesiastical History of Fngland to the Eighteenth Century. London, 1756 . TRector of Queentitho, London, pro-Anglican)

W11liams, J. K. Accounts of the Monastic Treasures. Edinburgh: Edinburgh Printing Company, 1836.

Wishart, Alfred W. A Short History of Honks and Monasteries. Trenton, New Jersey: Albert Brandt, 1900. (Justifies Henry's actions)

Woodhouse, F. C. Monasticism Ancient and Modern. London: Gardner, Darton and Company, 1896.

Wright, Thomas. Three Chapters of Ietters Rolating to the Suppression of Honasteries. Iondon: John Bowyer Fichols and Son, 1843 . 